\title{
THE EFFECTS OF GROWTH HORMONE ON PRIMARY BOVINE MAMMARY CELL MODELS
}

\author{
A Thesis \\ presented to \\ the Faculty of California Polytechnic State University, \\ San Luis Obispo
}

In Partial Fulfillment of the Requirements for the Degree

Master of Science in Agriculture, with Specialization in Animal Science by

Lisa McDonnell

November 2011 
(C) 2011

Lisa McDonnell

\section{ALL RIGHTS RESERVED}




\section{COMMITTEE MEMBERSHIP}

TITLE:

AUTHOR:

DATE SUBMITTED:

COMMITTEE CHAIR:

COMMITTEE MEMBER: $\quad$ Michael Black, Professor

COMMITEE MEMBER: Russ Hovey, Associate Professor
Daniel Peterson, Associate Professor
The effects of growth hormone on primary bovine mammary cell models

Lisa McDonnell

October 2012 


\section{ABSTRACT \\ THE EFFECTS OF GROWTH HORMONE ON PRIMARY BOVINE MAMMARY CELL MODELS}

\section{Lisa McDonnell}

The ability of exogenous growth hormone $(\mathrm{GH})$ to increase milk yield through insulin-like growth factor-1 (IGF-I) in dairy cows is well characterized. However, recent studies utilizing mammary epithelial cell lines indicate a direct effect of GH on mammary epithelial cells (MEC). To test if these observations are relevant in vivo and if this response differs between dairy breeds, three mammary models were utilized. Mammary explants from a lactating Jersey cow were cultured in classical lactogenic media (dexamethasone, insulin, and prolactin) with 0 or $10 \mathrm{ng} / \mathrm{mL}$ of recombinant bovine $\mathrm{GH}$ for 12h. Primary MEC from lactating Holstein and Jersey cows were cultured in classical lactation media with 0 or $10 \mathrm{ng} / \mathrm{mL}$ of $\mathrm{GH}$ for 2, 4, and 7 days. And lastly, MEC isolated from pooled Holstein or pooled Jersey milk were cultured in the same conditions as primary MEC. The response to $\mathrm{GH}$ was quantified by the relative abundance of mRNA for two milk protein genes ( $\alpha$-lactalbumin and $\alpha_{\mathrm{S} 1}$-casein), the GH receptor, IGF-I and insulin-like growth factor binding protein-3 (IGFBP-3) as determined by quantitative RTPCR. The abundance of $\alpha$-lactalbumin mRNA in explants was increased in response to GH. After 2 days, Jersey primary MEC showed an increase in GH receptor mRNA, in addition to a noteworthy trend of increasing abundance of IGFBP-3 regardless of GH treatment. After 4 days, Holstein primary cells cultured with GH had decreased IGFBP-3 mRNA. After 7 days, primary cells isolated from Holstein and Jersey mammary tissue showed a slight response to GH. Mammary cells from milk mirrored the responses to GH observed in primary cells: MEC isolated from Holsteins had decreased IGFBP-3 mRNA after 4 days of treatment with GH and MEC isolated from Jerseys showed the same trend of increasing IGFBP-3 abundance between 2 and 4 days, but with no difference between $\mathrm{GH}$ treatments. These results indicate that the effect of GH may differ between breeds and indicate $\mathrm{GH}$ has a direct effect on mammary epithelial cells, possibly including effects on the abundance of IGFBP-3 mRNA.

Keywords: mammary, primary cells, growth hormone, IGF-I, IGFBP-3 


\section{ACKNOWLEGDEMENTS}

I would like to thank Dr. Peterson for his guidance and direction during the course of this project. I would also like to thank my lab-mates, Tasha Johnson, Molly Strong, and Laura Strand, for their support, both technical and moral. And lastly, I would like to thank my parents, Tom and Sandra, for their tireless encouragement. 


\section{$\underline{\text { Table of Contents }}$}

LIST OF TABLES .......................................................................................................... viii

LIST OF FIGURES ……......................................................................................................... ix

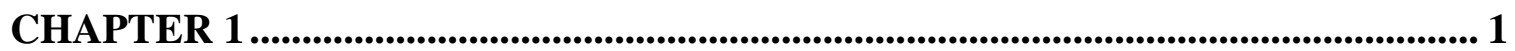

Literature Review ................................................................................................................................ 1

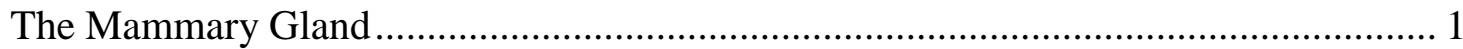

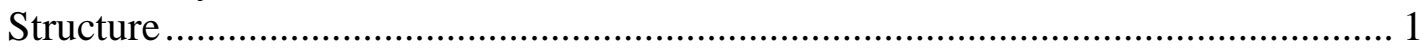

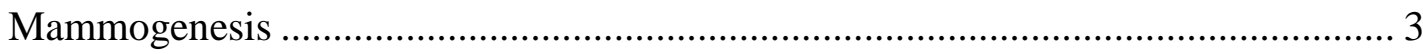

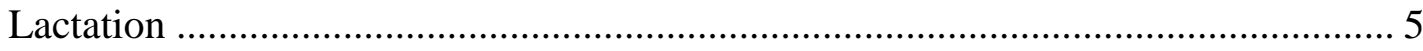

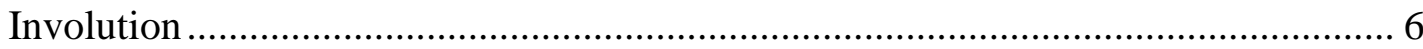

The mammary alveolar epithelial cell .................................................................. 8

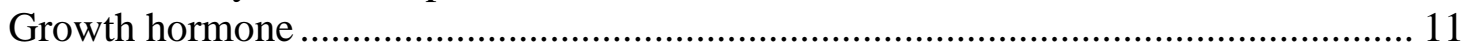

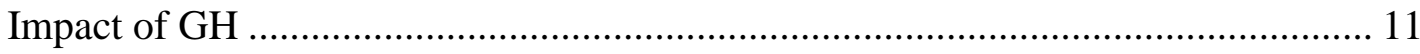

Growth hormone structure and secretion ............................................................ 12

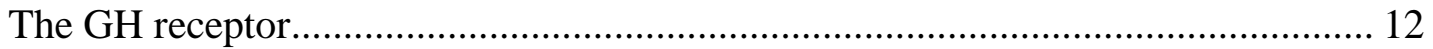

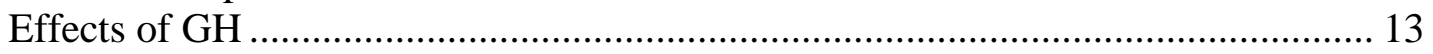

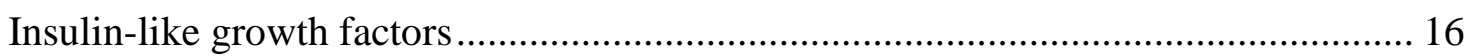

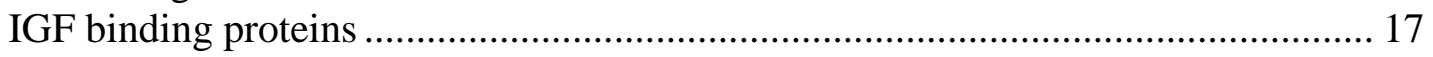

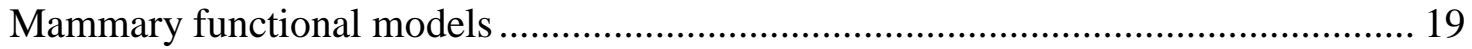

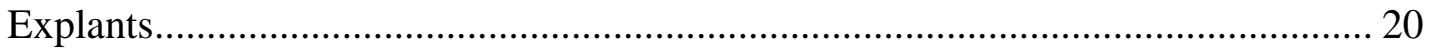

Primary cells .......................................................................................... 21

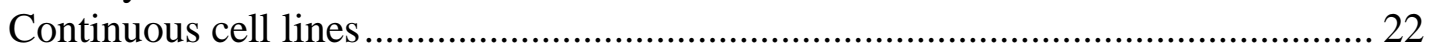

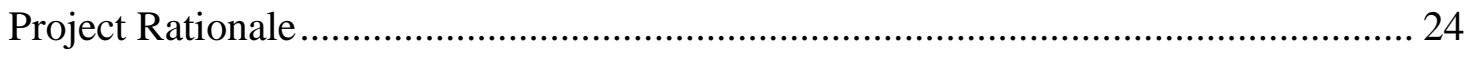

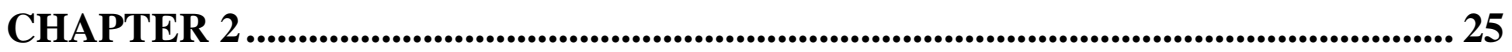

The Effects of Growth Hormone on Primary bovine Mammary Cell Models........... 25

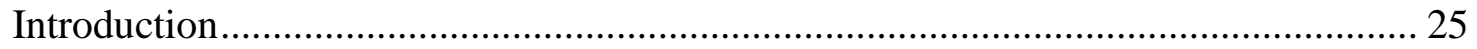

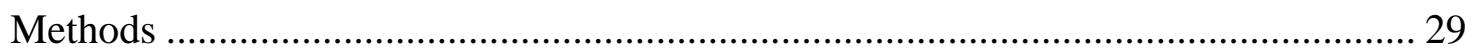

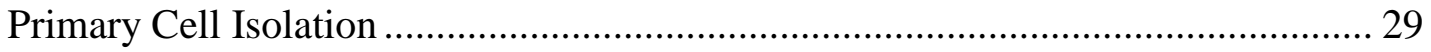

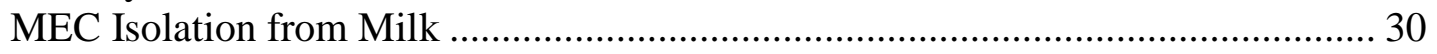

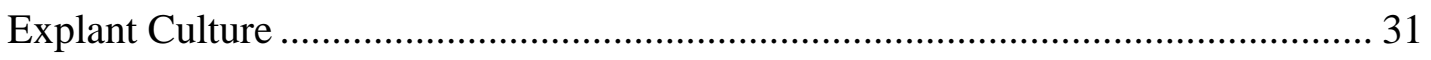

Primary Cell Culture ............................................................................................ 31

Culture of MEC from Milk ............................................................................... 32

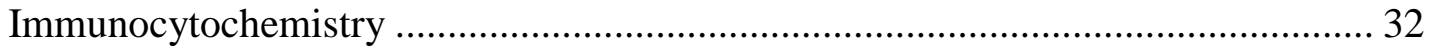

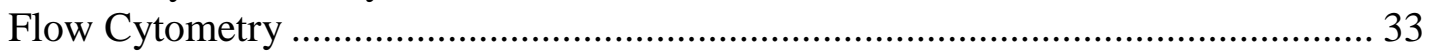

RNA Extraction and cDNA synthesis................................................................. 33

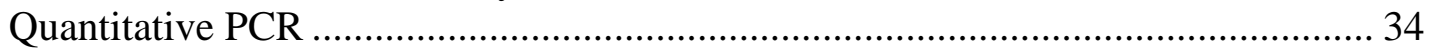

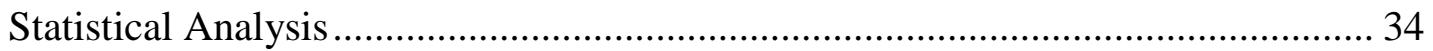

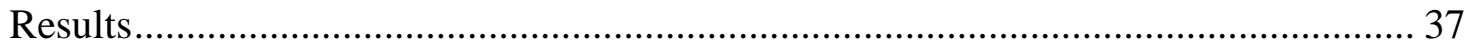

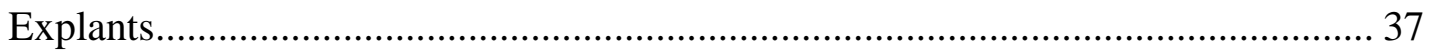

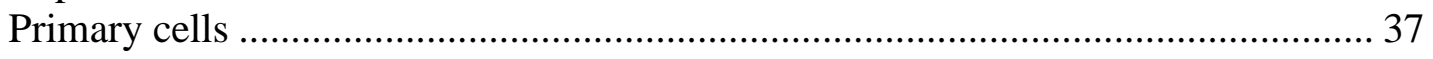

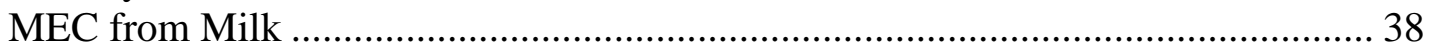

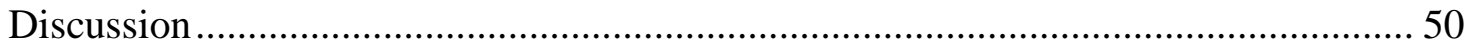




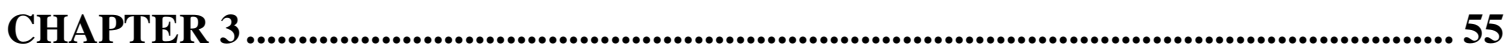

Limitations and Conclusions..................................................................................... 55

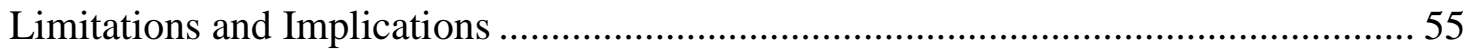

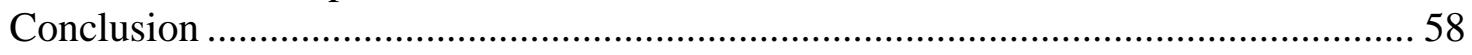

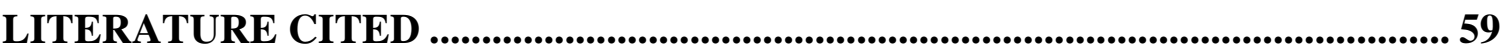

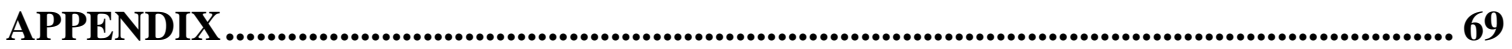

Quantitative PCR data ................................................................................................... 69

Mammary explants from a Jersey cow (Tables 1-5): raw qPCR values

corresponding to results presented in Figure 4. ..........................................................69

Primary MEC from a Jersey cow (Tables 6-10): raw qPCR values

corresponding to results presented in Figure 5.

Primary MEC from a Holstein cow (Tables 11-15): raw qPCR values

corresponding to results presented in Figure 6.

MEC from Holstein milk (Tables 16-20): raw qPCR values corresponding to results presented in Figure 7.

Primary MEC from a Holstein cow (Table 21-25): raw qPCR values corresponding to results presented in Figure 8 .

Primary MEC from a Jersey cow (Table 26-30): raw qPCR values corresponding to results presented in Figure 9.

MEC from Holstein milk (Tables 31-35): raw qPCR values corresponding to results presented in Figure 10.

MEC from Jersey milk (Tables 36-40): raw qPCR values corresponding to results presented in Figure 11 


\section{List of Tables}

Table 1: Primers based on bovine mRNA sequences used for quantitative PCR in

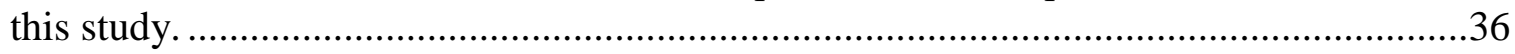

Table 2: Primary MEC flow cytometry values.......................................................... 41 


\section{List of Figures}

Figure 1: MEC band at the interface of media and 5\%BSA-Ficoll layers........................35

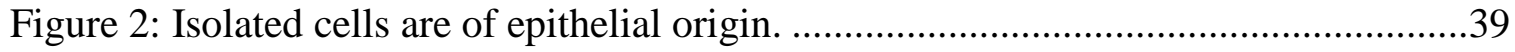

Figure 3: Isolated cells are positive for epithelial marker proteins ..............................40

Figure 4: $\alpha$-lactalbumin mRNA abundance in Jersey mammary explants is increased after $12 \mathrm{~h}$ in response to $\mathrm{GH}$

Figure 5: In primary MEC from a Jersey cow, GHR mRNA abundance is increased in response to $\mathrm{GH}$ after $7 \mathrm{~d}$.

Figure 6: Primary MEC from a Holstein do not respond to treatment with GH after $7 \mathrm{~d}$

Figure 7: In MEC from Holstein milk, $\alpha$-lactalbumin mRNA abundance is increased in response to treatment with $\mathrm{GH}$ after $7 \mathrm{~d}$.

Figure 8: Primary Holstein MECs have decreased IGFBP-3 mRNA abundance after $4 \mathrm{~d}$ of treatment with $\mathrm{GH}$.

Figure 9: Primary Jersey MEC have increased GHR mRNA abundance after $2 \mathrm{~d}$ in response to treatment with $\mathrm{GH}$.

Figure 10: Holstein MEC from milk have decreased mRNA abundance of IGFBP3 after $4 \mathrm{~d}$ in response to treatment with $\mathrm{GH}$.

Figure 11: In MEC from Jersey milk, the mRNA abundance for any transcript evaluated was not affected by GH.

Figure 12: Proposed model of direct effect of GH on primary bovine mammary epithelial cells. 


\section{CHAPTER 1}

\section{LITERATURE REVIEW}

\section{The Mammary Gland}

The mammary gland is a secretory organ unique to the class Mammalia. The mammary gland synthesizes and secretes the components of milk, which provides nutrition to their young. Milk is a complete and easily digestible nutrient source, providing all of the necessary nutrients for growth including proteins, sugars, lipids, vitamins, and minerals. In addition to nutrients, milk also provides immunological components, such as immunoglobulins and white blood cells, which aid in protecting the neonate from disease (Schmidt, 1971; Larson \& Smith, 1974). All of these components are secreted into the gland's complex duct system for storage and eventual ejection.

The mammary gland undergoes four distinct stages of development: mammogenesis, lactogenesis, galactopoiesis, and involution. The development of the mammary gland is a continual process because the gland is capable of proliferation, differentiation, and involution many times throughout the adult life of the female animal. Each stage of development is directed by a unique hormonal milieu. Estrogens, growth hormone $(\mathrm{GH})$, progesterone, prolactin, insulin, and glucocorticoids all have a role in the development, function, and regression of the mammary gland which will be described in this section.

\section{Structure}

The form of the mammary gland differs by species, with some having breasts, rows of teats, or udders. Each type of mammary gland has unique characteristics. The breast is type of mammary gland found in humans and non-human primates. Breasts, in 
particular, are usually two symmetric glands and are thoracically located. The structure of the mammary glands of canines, pigs, and rodents is markedly different from an udder. Mammary glands in these species can be more numerous (1-9 pairs of glands) and are located along the ventral side of the animal and teats are located from the thoracic region through the inguinal region. Additionally, species with breasts or rows of teats have significantly less connective tissue, though the structure of alveoli and ductal systems remain similar (Sheffield, 1988). Ruminants, such as cattle, sheep and goats, exemplify the udder mammary structure.

The udder is comprised of a secretory duct system, circulatory and lymph systems, and a physical support system. The udder is inguinally located below the body and is formed by one or two pairs of mammary glands ending in teats. The gland is supported internally by extensive connective tissue and ligaments, notably the median suspensory ligament, which aids in suspending the udder below the abdomen while keeping it close to the body wall. Each teat is the drainage canal for one cistern. The gland cistern collects secreted milk that drains from many ducts. The ductal system is highly branched and leads from millions of lobuloalveoli. Lobuloalveoli are clusters of alveoli, where each alveolus is made up of functionally differentiated mammary epithelial cells arranged in a single layer surrounding an open lumen into which components of milk are secreted. The single layer of cells around the lumen is surrounded by myoepithelial cells that contract the alveolus to aid in the flow of milk through the ducts and ejection of milk into the cistern and out of the gland (Larson \& Smith, 1974). Surrounding the alveoli is the mammary stroma, comprised of connective and adipose 
tissue and a well developed vasculature (Larson \& Smith, 1974; McManaman \& Neville, 2003).

\section{Mammogenesis}

The origination and development of the mammary gland begins during embryogenesis, during which time the mammary fat pad also develops (Sheffield, 1988; Daniel \& Smith, 1999). Interaction with the mesenchyme appears to be the most influential factor over the development of the mammary rudiment during embryogenesis and this interaction remains critical for proper development and function later in life (Daniel \& Smith, 1999; Kleinberg, 1997). Growth of the mammary gland prior to puberty is proportional to body growth (Knight, 2000). The rudimentary ductal system present at birth will elongate, but with limited branching. Development of secretory alveoli does not occur until the onset of pregnancy (Knight, 2000). Other mammary gland tissues, such as connective, circulatory and lymph tissues, are developed during pre-pubertal growth (Takeishi et al., 1980).

At the onset of puberty, the combined effects of pituitary and ovarian hormones stimulate further development of the mammary gland. The synergistic effects of estrogen and GH serve to lengthen and branch the rudimentary ductal system (Kleinberg, 1997). Estrogen receptors begin to appear in high concentrations in the mammary gland during puberty, leading to ductal development within the gland in response to estrogen (Mallepell et al., 2006; Robinson et al., 1995). Prolactin, secreted from the anterior pituitary in response to rising levels of estrogen, acts through its receptor on mammary cells to stimulate some post-pubertal development of alveoli and limited ductal elongation (Ceriani, 1974). It has been suggested that prolactin stimulates paracrine 
release of insulin-like growth factor II (IGF-II) within the mammary gland, which stimulates development of alveoli (Brisken et al., 2002). GH also promotes mammary epithelial proliferation, but to a much lesser extent than seen during gestation (Carstens $e t$ al., 1997; Sejrsen et al., 1986). Stromal-epithelial interactions during puberty are especially critical, as the effects of GH are exerted through GH receptors (GHR) on stromal cells that produce local IGF-I that acts directly on mammary epithelial cells (MEC). This paracrine action is essential for normal mammary development (Kleinberg \& Ruan, 2008; Ruan \& Kleinberg, 1999; Akers et al., 2000). The presence of GH is critical for the proper development of the mammary gland. In studies where hypophysectomized, ovariectomized, and adrenalectomized mice were given exogenous injections of hormones, no mammary development occurred at puberty in the absence of GH (Kleinberg, 1997). In addition to GH, estrogens are critical for normal mammary development during puberty, particularly for hormone-dependent ductal elongation and side branching (Brisken \& O'Malley, 2010). For example, the mammary gland failed to develop in wild type mice with a cleared fat pad implanted with estrogen receptor negative epithelial cells (Mallepell et al., 2006). Pubertal development of the mammary gland continues with each successive estrous cycle, until ducts reach the edges of the mammary fat pad, which marks the end of major pubertal development (Richert et al., 2000).

The onset of pregnancy elicits the next stage of development in the mammary gland. Pregnancy induces major changes in the mammary gland to support terminal differentiation of alveolar structures in preparation for lactation. The ductal system undergoes significant side-branching, alveolar development occurs, and MEC begin to 
differentiate into functional secretory cells (Hovey et al., 2002; McManaman \& Neville, 2003). Proliferation of MEC and development of alveoli are critical for milk production (Knight, 2000). Progesterone and prolactin play major roles in the proliferation of MEC and development of alveoli. Under the influence of progesterone, branching of the ductal system becomes extensive and there is considerable development of lobulo-alveolar structures (Larson \& Smith, 1974). Sensitized by the effects of progesterone, the mammary gland responds to prolactin through the extensive development of lobuloalveolar structures (Hovey et al., 2003). Additionally, the development of the mammary gland during pregnancy is modulated by the number of previous pregnancies. The mammary gland of multiparous animals responds more rapidly and robustly to progesterone and estrogen through increased proliferation and lobuloalveolar development (Ceriani, 1974).

\section{Lactation}

The sum of the changes acquired during pregnancy results in full functional differentiation of the MEC in preparation for synthesis and secretion of milk. The secretory capacity gained by MEC during pregnancy is fully functional at the time of parturition. There is an increase in Golgi, mitochondria, and endoplasmic reticulum in differentiated MEC, in addition to more secretory vesicles (McManaman \& Neville, 2003; Larson \& Smith, 1974). Increasing levels of prolactin and decreasing levels of progesterone, which allows for secretion and ejection of milk, induce the onset of lactation (Knight, 2000). Synergistic effects of prolactin and GH maintain the production of milk components. Prolactin and GH, through activation of their receptors, activate signal transducer and activator of transcription (STAT) variants, and particularly STAT5. 
One of the major roles of STAT5 is increasing the transcription of milk protein genes (Rosen et al., 1999). Prolactin stimulates the production of milk proteins in the MEC. GH indirectly acts on MEC, through the production of IGF-I, to stimulate lipid synthesis by maintaining activation of lipoprotein lipase and acetyl-CoA carboxylase (Knight, 2001; Flint \& Knight, 1997; Braun \& Severson, 1992). Additionally, cortisol is released during milking and is required to maintain secretory activation of MEC (Gorewit et al., 1992; Sejrsen et al., 2006). Although hormones play an important role in maintaining lactation, one of the most important and fundamental signals is suckling and/or milk removal (Svennersten-Sjaunja \& Olsson, 2005). Tactile stimulation of the teat results in release of the hormone oxytocin from the pituitary, which is required for full milk ejection (Svennersten-Sjaunja \& Olsson, 2005; Gorewit et al., 1992). The absence of any of these signals leads to the cessation of lactation through involution of the mammary gland.

\section{Involution}

Involution of the mammary gland at the end of lactation is the result of a complex signaling process through which the gland sheds MEC and mammary tissue is remodeled to a pre-pregnancy like structure (Baxter et al., 2007). Regression of the mammary gland following the lactation cycle is a result of extensive apoptosis of MEC (Marti et al., 1994). The major signal for mammary involution is the cessation of suckling which in turn leads to other signals resulting in activation of apoptosis. The accumulation of milk in the alveolar lumen may be a signal for involution itself, or may contribute to the accumulation of apoptotic signals in the gland (Li et al., 1997). Additionally, falling levels of hormones required for lactation contribute to regression of the gland. These 
signals lead to the activation of apoptotic pathways within MEC and regression of the gland to pre-gestational quiescence (Baxter et al., 2007).

The result of involution is a loss of active secretory cells; however the gland retains a population of MEC that have not terminally differentiated. These cells are retained and protected from the process of involution. This population of stem cells is capable of responding to hormonal stimuli at the onset of the next gestation and proliferate to generate new secretory cells and a "new" functional gland (Malinowski, 2005). 


\section{The mammary alveolar epithelial cell}

The major developmental stages of the mammary gland revolve around the proliferation and differentiation of mammary epithelial cells (MEC). The functional units of the mammary gland are MEC, which synthesize and secrete the components of milk. This specialized cell absorbs nutrients from the blood stream, synthesizes components of milk, and secretes them into the alveolar lumen. The alveolar lumen is composed of MEC arranged in a single layer surrounding the lumen, into which milk components are secreted. Nutrients are absorbed through the basolateral membrane of MEC and milk components are secreted through the apical membrane of MEC (Wilde et al., 1995). Attaining this polarization is critical to the cell's ability to successfully secrete milk components. Without it, functional lactation fails (Tateyama et al., 1988).

During lactation MEC synthesize and secrete proteins unique to milk- caseins, lactalbumins, and lactoglobulins. Milk protein gene expression is controlled through the synergistic interactions of prolactin, insulin, and dexamethasone (Menzies et al., 2009; Svennersten-Sjaunja \& Olsson, 2005). These hormones, through a signal cascade activated by binding their respective receptors, activate transcription factors that promote the transcription of milk protein genes (Rosen et al., 1999). Caseins, which are hydrophobic milk proteins, are secreted in a micelle that also assists in the transport of calcium, lactose, and phosphate into milk (Kumar et al., 1994; Shennan \& Peaker, 2000). $\alpha$-lactalbumin is a protein synthesized in MEC in response to hormonal stimuli during lactation. In addition to being secreted as a milk protein to provide nutrients to the neonate, $\alpha$-lactalbumin also complexes with galactosyltransferase within the cell to form lactose synthase (Kresge \& Simoni, 2006). Lactose synthase catalyzes the synthesis of 
lactose from galactose and glucose in the Golgi (Larson, 1969). Without $\alpha$-lactalbumin, lactose synthase is not functional (Kresge \& Simoni, 2006). In this way, the expression of $\alpha$-lactalbumin, in response to prolactin, is directly linked to successful production of lactose during lactation. The concentration of lactose, in turn, regulates the volume of milk produced by changing osmotic pressure in the alveolar lumen which draws water from the blood into the lumen to balance the pressure (Shennan and Peaker, 2000).

In addition to milk specific proteins, MEC also synthesize and secrete lipids, predominately triacylglycerol (Shennan \& Peaker, 2000). The synthesis of fatty acids is markedly different between mammalian species. Non-ruminants are able to utilize glucose for the synthesis of fatty acids through its conversion to citrate, which in turn can be cleaved by citrate lyase resulting in the formation of acetyl CoA, which can be utilized for fatty acid synthesis (Larson \& Smith, 1974). In ruminants, the use of glucose is prevented due to the absence of citrate lyase. Fatty acids in ruminant milk are either derived from the blood by MEC or are synthesized by MEC from acetate and $\beta$ hydroxybutyrate, both of which are in high concentration in the ruminant as a result of microbial fermentation in the rumen (Larson \& Smith, 1974). Lipids are synthesized at the endoplasmic reticulum and are secreted as globules, surrounded by a portion of the apical cell membrane (Ernens et al., 2007). Lipid droplets formed in the cytoplasm of MEC protrude out against the plasma membrane, eventually becoming enveloped, and extruded from the cell resulting in a secreted milk fat globule surrounded by plasma membrane (Keenan, 2001).

Nutrients are absorbed by MEC through the basolateral membrane and used to synthesize the components of milk. Glucose and ions, such as potassium and sodium, 
cross the MEC basolateral membrane through facilitated diffusion (Zhao et al., 1999; Shennan \& Peaker, 2000). Trace elements, such as zinc and copper, are moved by active transporters (Mather \& Keenan, 1998; Truchet \& Ollivier-Bousquet, 2009; Lonnerdal, 2007). Nutrients absorbed from the blood will be incorporated into larger molecules in milk, such as proteins or triacylglycerol, and secreted into the alveolar lumen, or be transported directly to the alveolar lumen. Components that characterize milk are caseins, milk fat (predominately triglycerides), and lactose (Akers, 1985). These are synthesized by MEC and secreted into milk along with other nutrients, such as vitamins and minerals. 


\section{Growth hormone}

\section{Impact of GH}

Milk is a complete nutritional source and widespread production and distribution provides a source of complete nutrition to an ever-growing population. Efficiency of milk production will be a key issue in both production of food for humans and efficient use of available resources. Improving the utilization of nutrients by production animals, in addition to genetic improvements, can make the production of milk more efficient (Capper et al., 2008). Early experiments in dairy cattle using crude pituitary extracts showed the presence of a factor which was a potent enhancer of milk yield (Cotes et al., 1949). Further purification identified it as growth hormone $(\mathrm{GH})$. Injections of exogenous $\mathrm{GH}$ or recombinant bovine somatotropin (rbST) improve feed conversion efficiency and increase milk yield in dairy cows. Recently, recombinant technologies have allowed the widespread use of exogenous GH in the dairy industry. In addition to providing a valuable food source, utilizing and maximizing exogenous $\mathrm{GH}$ technologies allows the current dairy cattle population to produce more milk while utilizing less feed. Efficiently using land and feed resources will continue to be a priority as the population expands and competition for land and resources increases (Capper et al., 2009; Capper et al., 2008).

Despite improvements to production, the widespread use of rbST in dairy cattle has been controversial due to a perceived risk to the consumer as a result of ingestion of milk from cows treated with rbST. There has been some concern that administration of rbST will increase the levels of IGF-I in milk, however any observed changes have been within the range of IGF-I normally present in milk (Dahl et al., 1991; Collier et al., 1999). 


\section{Growth hormone structure and secretion}

GH, also called somatotropin, is a peptide hormone consisting of 190 or 191 amino acids. Four variants of GH have been described: either a leucine or valine at position 127 , and either a 190 -amino acid variant with a phenylalanine at the $\mathrm{N}$-terminus, or a 191-amino acid protein with an alanine at the N-terminus (Etherton \& Bauman, 1998; Bauman \& Vernon, 1993). The potency of variants has been studied and the variant with a valine at position 127 has been reported to be a more potent stimulator of galactopoiesis, while no difference between N-terminal variants was observed with respect to galactopoiesis (Eppard et al., 1992).

Growth hormone releasing hormone, secreted from the hypothalamus, stimulates the secretion of GH from the pituitary gland. Somatostatin, also secreted from the hypothalamus, inhibits the release of GH (Tuggle \& Trenkle, 1996). GH is secreted from the anterior pituitary gland in a pulsatile fashion (Gluckman et al., 1987) and acts on target tissues to promote growth. Secretion from the pituitary is the major source of GH, however several other tissues also synthesize GH, including brain, placental, mammary and pineal gland (Butler \& Le Roith, 2001).

\section{The GH receptor}

The GH receptor (GHR) is a member of the cytokine receptor super-family and transmits signals through its membrane spanning structure via several signal transduction pathways (Shafiei et al., 2006). The GHR shares a similar homology with other receptors, such as the prolactin and interleukin receptors (Butler \& Le Roith, 2001). Activation of the GHR results in the phosphorylation and activation of Janus kinase 2 (JAK2) that results in the phosphorylation of STAT proteins (STAT1, 3, and 5), mitogen- 
activated protein kinase (MAPK), and phophatidylinositol-3 kinase (PI3K) (CarterSu et al., 1996; Barclay et al., 2010). The JAK2 pathway is particularly important for expression of IGF-I and IGF-I binding protein transcripts. Activated STAT5 is able to regulate gene expression by binding DNA and activating gene transcription. The critical importance of STAT5 activation, by both GH and prolactin, is highlighted by the discovery that STAT5 deficient mice are unable to lactate (Liu et al., 1997).

The GHR is present on several tissue types including liver, muscle, bone, mammary, adipose, brain, and immune tissue (Kopchick \& Andry, 2000). Via these receptors, GH is able to alter metabolic processes which result in an increase body mass and length. There have been conflicting reports on the expression of the GHR on the MEC. Early studies claimed that while the GHR was expressed in the mammary gland, it was most likely on stromal cells and not MEC (Peel \& Bauman, 1987; Glimm et al., 1990). More recent studies utilizing more sensitive technologies have reported the expression of GHR mRNA and GHR on the membrane of MEC (Sakamoto et al., 2005; Plath-Gabler et al., 2001). These findings led to investigations into the possibility of GH acting directly on MEC, in addition to its effects through somatomedins.

\section{Effects of GH}

GH influences the development, growth, and metabolism of cells and tissues. Both direct and indirect effects of GH have been described: the direct effects of $\mathrm{GH}$ include changes in gene expression influencing and metabolism and differentiation of tissues, such as bone and mammary (Bolander, 1989). Indirect effects of GH are mediated by somatomedins (Peel et al., 1981; Bauman \& Vernon, 1993). The major somatomedin associated with GH is insulin-like growth factor-1 (IGF-I), which is 
produced and secreted by the liver in response to GH. GHR is present in high concentrations on hepatocytes and allows GH to stimulate the production and secretion of IGF-I by the liver (Etherton \& Bauman, 1998; Gluckman et al., 1987). IGF-I acts through its receptor, present on most tissue types to induce changes to cell metabolism, division, and survival (Le Roith et al., 2001). High serum concentrations of IGF-I contribute to negative feedback and inhibit the release of GH (Kopchick \& Andry, 2000; Berelowitz et al., 1981).

Early experiments with pituitary extracts showed that they could promote growth and increase milk yield (Cotes et al., 1949; Lee \& Schaffer, 1934). Exogenous injections of GH have been shown to increase milk yield and improve lactation persistency in dairy cattle without altering the composition of milk (Hutton, 1957; Akers, 2006). Advances in recombinant technologies made the commercial application of GH feasible to the dairy industry. Recombinant bovine GH was approved in 1993 by the FDA and marketed as Posilac ${ }^{\circledR}$ by Monsanto (Capper et al., 2008). The increase in milk yield by GH is accomplished through several mechanisms. Firstly, nutrient partitioning shunts nutrients in favor of the mammary gland through alterations in nutrient usage by other tissues, by increasing lipolysis in adipose tissue and decreasing glucose oxidation in muscle (Bauman \& Currie, 1980; Pocius \& Herbein, 1986). These actions result in more nutrients being available to the mammary gland for synthesis of milk components (McDowell et al., 1987). Secondly, GH contributes to cell survival by inhibiting apoptotic pathways and activating pathways involved with cell survival (Flint \& Knight, 1997). This effect is primarily directed by IGF-I produced by the liver. 
The metabolic effects of $\mathrm{GH}$ are a result of a direct action on target tissues, notably adipose and liver, altering their utilization of nutrients. GH increases lipolysis in adipose tissue to release nutrients for use by other tissues, such as bone, muscle and mammary tissue (Butler \& Le Roith, 2001). GH increases lipid synthesis in animals with a positive energy balance, particularly growing animals, and increases lipolysis in animals with a negative energy balance, for example a lactating dairy cow. This allows animals to grow and animals with high energy demands to better utilize available nutrients—-such as in growing pigs and lactating dairy cows (Bauman \& Currie, 1980). GH also increases protein accumulation, but this effect is largely mediated by increased concentrations of IGF-I (Etherton \& Bauman, 1998). Additionally, GH can stimulate glucose uptake by tissues in an insulin-dependent manner and this may be mediated by recruitment of the insulin receptor substrate by the GHR (Butler \& Le Roith, 2001). 


\section{$\underline{\text { Insulin-like growth factors }}$}

There is clear evidence of a close relationship between GH and insulin-like growth factors (IGF). The IGF family includes two growth factors, IGF-I and IGF-II, which share high amino acid homology. Insulin-like growth factors (IGF) also share high homology with insulin $(\sim 50 \%)$; however IGF retain the C peptide that is cleaved from pro-insulin to make the functional form of insulin. IGF-I and IGF-II both stimulate growth, however IGF-II is more involved in fetal growth, while IGF-I is involved in postnatal growth (Bolander, 1989; Le Roith et al., 2001). IGF-I and -II also promote mammary development, facilitating ductal elongation and branching, and alveolar development (Rowzee et al., 2009). In particular, IGF-I increases protein synthesis, cellular proliferation, and cell survival (Berry et al., 2001).

IGF are capable of binding three receptors with varying affinities: the IGF-I receptor (IGFR-1), the IGF-II receptor (IGFR-2), and the insulin receptor (IR). IGF receptors are present on a wide variety of tissues as is evident by the wide spread effects of IGF-I on multiple body systems. IGFR-1 is the primary receptor for signaling the actions of IGF-I, but some functions may be mediated through IGFR-2. Additionally, the IR binds IGF with 100-fold lower affinity than insulin (Stewart \& Rotwein, 1996; Leroith et al., 1995). The IR and the IGFR-1 share 70\% homology (Baserga et al., 2003). Both of these receptors are members of the tyrosine kinase receptor family and recruit the IR substrate and activate downstream signaling pathways such as PI3K and MAPK (Bolander, 1989). At high concentrations, IGF-I can bind the IR and can induce the uptake of glucose by tissues (McGuire et al., 1992). 
Synergistic hormonal interactions are critical to the development and function of the mammary gland (Topper \& Freeman, 1980). The secretion of IGF-I, the major somatomedin associated with many of the effects of GH, is induced by GH (Berry et al., 2001). IGF-I is primarily secreted by the liver. Metabolic effects of IGF-I include increased protein synthesis and decreased proteolysis, in addition to increased proliferation through stimulation of cell cycle progression (Sejrsen et al., 2006; Le Roith et al., 2001). Additionally, IGF-I promotes cell survival through activation of Akt (Kulik et al., 1997).

Although the liver is the primary source of IGF-I production, other tissues such as mammary stroma can secrete IGF-I, which can act in a paracrine manner on MEC. MEC have not been shown to secrete IGF-I (Baumrucker \& Erondu, 2000). When considered with MEC expression of the GHR, this further supports investigation into a separate, direct role of GH on MEC.

\section{IGF binding proteins}

The majority of IGF-I and IGF-II are bound to binding proteins in serum (Cohick \& Clemmons, 1993). The involvement of IGF binding proteins (IGFBP) in the GH/IGF axis affects the ability of IGF to interact with their receptors. There are at least six different IGF binding proteins whose secretion pattern and function differ (Knight, 2000). IGFBP aid in transport of IGF, prolong the half-life of IGF in circulation, and localize IGF to particular tissues through interactions with cell surface proteins and extracellular matrix proteins (Cohick, 1998; Cohick \& Clemmons, 1993; Yamada \& Lee, 2009). The binding affinity of IGF for each binding protein differs between isoforms, tissues, and their interaction with other molecules (Rowzee et al., 2009). 
IGFBP-3 and IGFBP-5 both have major functions with respect to the mammary gland. In dairy cattle, the predominant IGFBP in serum is IGFBP-3 which binds the majority of IGF-I in circulation (Baumrucker \& Erondu, 2000; Plath-Gabler et al., 2001). IGFBP-3 is synthesized and secreted by mammary epithelial cells both in vivo and in vitro (Berry et al., 2001; Gibson et al., 1999; Cohick \& Turner, 1998). IGFBP-3 concentrations have been shown to be higher during mammogenesis and involution than during lactation (Plath-Gabler et al., 2001; Baumrucker \& Erondu, 2000). It has been shown that IGFBP-5 is in high concentrations in the mammary gland during involution and appears to be involved in mediating the process of involution (Flint et al., 2003; Sakamoto et al., 2007). 


\section{Mammary functional models}

The mammary gland provides an excellent model in which to study development, differentiation, and lactation; however, due to the numerous interconnected systems in a whole animal, a more independent model may be useful in deducing the role and functions of specific stimuli. Apart from the whole-animal, there are several models that are useful in understanding the function of the mammary gland, each of which seek to best mimic the in vivo conditions of the mammary gland while eliminating confounding systemic factors. Many studies report mammary tissue and cells in vitro are capable of responding to structural, nutritional, and hormonal stimuli (Keys et al., 1997; Campbell et al., 1991; Mills \& Topper, 1970; Riley et al., 2008; Mallepell et al., 2006; Gibson et al., 1999). However, each of these models has limitations and varying culture requirements to achieve function in vitro.

One of the most fundamental requirements for normal function of MEC is polarization, which in some models must be achieved by a three-dimensional culture system. Failure to determine cellular orientation, and consequently polarization, results in reduced expression of indicators of differentiation and lactation in MEC in vitro (Tateyama et al., 1988; Kawano et al., 1988). For some in vitro MEC models, a collagen gel matrix is needed to provide support for proper polarization and expression of genes associated with the differentiated phenotype (Riley et al., 2010; Richards et al., 1983). Matrices can also be made from various materials designed to mimic the extra cellular matrix and thereby assist the orientation and polarization of cells in vivo (Grant et al., 1985). These matrices help to replicate the 3D structure and orientation of mammary tissue. 


\section{Explants}

Explants are small pieces of excised mammary tissue and are composed of the many cells types present in the mammary gland including connective, adipose, vascular, and MEC. Structural orientation is a key component of MEC differentiation and lactogenesis. By culturing excised tissue, the physical orientation of the cells is maintained. (Ebner et al., 1961). Explants, however, can only be cultured for a relatively short time (up to 5 days) in vitro which makes long term studies difficult (Ip \& Darcy, 1996). Additionally, it can be a costly and invasive procedure to continually excise mammary tissue; new tissue samples need to be obtained for every experiment because explants do not undergo proliferation in vitro and, unlike isolated primary cells, will not survive cryopreservation. Due to the invasiveness of excising mammary tissue, tissue is often collected after slaughter; however this does not allow repeated sampling from the same animals. Despite these drawbacks, explants provide an excellent model of the mammary gland in vitro and have been used by many groups to study functional differentiation, lactation, and involution. Explants respond to hormonal stimuli in a similar fashion as the mammary gland; they are capable of differentiating, synthesizing and secreting milk proteins, IGFBP and, when co-cultured with liver and adipose tissue, lipids (Campbell et al., 1991; Keys et al., 1997; Keys et al., 1992). However, they are not a homogeneous population of cells and investigating the response of a single cell type within the tissue can be confounded by stromal interactions between various cell types present. 


\section{Primary cells}

Primary cells are isolated from mammary tissue and, depending on the method of isolation, can be a relatively homogenous population of $\mathrm{MEC}$, free of other cell types found in the mammary gland. The isolation of this singular cell type allows for investigation into the direct effects of signaling molecules, such as GH, upon the MEC without confounding influences from the surrounding tissue, which is especially important given the prevalence of paracrine signaling in the mammary gland. However, isolated MEC have been dissociated from their connective tissue, and therefore the use of extra-cellular matrix scaffolds is common in single cell culture systems. Despite these extra-cellular changes, primary cells provide an excellent model to study the proliferation and differentiation of MEC. Using primary cell models, the importance of insulin, progesterone and epidermal growth factor in MEC proliferation has been shown (Ip \& Darcy, 1996). Additionally, the importance of prolactin, hydrocortisone, and insulin to the expression of milk proteins, especially casein, has been shown (Suard et al., 1983; Wheeler et al., 1995). Studies using primary cells show their capability to synthesize and secrete lactose and lipids (Rohlfs et al., 1993; Taketani \& Oka, 1981).

Mammary tissue is not the only source of primary MEC; primary MEC can also be isolated from milk. Several groups have isolated MEC from raw milk from humans, cows, and goats (Gaffney, 1982; Boutinaud et al., 2002; Boutinaud et al., 2008; Buehring, 1990; Ceriani et al., 1979). MEC are sloughed from the alveolus into milk and can be collected from samples of raw milk (Boutinaud \& Jammes, 2002). Several factors affect the concentration and viability of MEC in milk, such as stage of lactation, parity, infection, and milking frequency (Boutinaud \& Jammes, 2002). The suitability of milk- 
derived MEC to represent the responses and functions of MEC has been evaluated by comparing the gene expression of mammary tissue to the gene expression of MEC derived from milk through RT-PCR (Boutinaud et al., 2008; Boutinaud et al., 2002). MEC derived from milk and mammary tissue have a significant correlation between the quantity and types of genes expressed (Boutinaud et al., 2002).

\section{Continuous cell lines}

Cell lines are immortalized cells capable of continuous division in vitro. They originate from cells isolated from tissue and through transfection or spontaneous mutation acquired the ability for indefinite proliferation. Cell lines provide a virtually infinite source of cells, however their infinite proliferative ability calls into question their accurate representation of normal biological systems. There are many mammary epithelial cell lines in use for multiple species. In particular, the MAC-T cell line was derived from normal Holstein bovine mammary tissue by Huynh et al. (1991) and transfected with the simian virus 40 large-T antigen. This transfection inhibits $\mathrm{p} 53$, a protein that regulates the cell cycle, allowing the cells to remain proliferative rather than reach senescence. MAC-T cells are capable of synthesizing milk proteins and lipids. In addition to the bovine derived MAC-T cell line, cell lines exist in other species including mice (COMMA-D, HC11) and humans (MCF-10A) (Ball et al., 1988; Soule et al., 1973; Danielson et al., 1984). Cell lines have also been developed from tumor cells in several species, such as mice (4T1), human (MCF-7), and rats (Rama 25) (Dulbecco et al., 1979; Aslakson \& Miller, 1992). There are limitations to using transformed cell lines, however. These limitations stem from the inherent dysregulation of the cell cycle required to 
achieve infinite proliferation and the possibilities of spontaneous mutations that may alter the ability of the cell line to respond in a similar fashion to its tissue of origin. 


\section{Project Rationale}

Utilizing two mammary cell models, this project aims to evaluate the response of primary bovine mammary cells to $\mathrm{GH}$ with an underlying comparison of the response between two dairy breeds. This investigation is based on the clear influence of GH on milk yield in several dairy breeds and previous observations in mammary cell lines that support a direct action of GH on MEC. The use of primary cells is critical for investigating the direct role of GH independent of IGF-I in normal cells. Isolated primary cells provide a model where the response of MEC can be evaluated, independent of other stromal interactions. While investigations utilizing cell lines are certainly valuable, validating their responses in models that more closely resemble normal cells is an important step in elucidating the active mechanisms at work. 


\section{CHAPTER 2}

\section{THE EFFECTS OF GROWTH HORMONE ON PRIMARY BOVINE MAMMARY CELL MODELS}

\section{$\underline{\text { Introduction }}$}

Early experiments in dairy cattle using crude pituitary extracts showed the presence of a factor which was a potent enhancer of milk yield (Cotes et al., 1949). Further purification identified it as growth hormone $(\mathrm{GH})$ and its administration could increase milk yield (Hutton, 1957). With the utilization of recombinant technologies, commercial administration of exogenous GH became feasible. Lactating animals respond to administration of exogenous $\mathrm{GH}$ by increasing milk production without altering composition (Hutton, 1957). Previous studies have reported that high-producing animals differ from low-producing animals in their response to exogenous $\mathrm{GH}$ and suggest that this difference is due to the animal reaching maximum potential of milk production (Nytes et al., 1990; Gibson et al., 1992) or differences in the potency of GH variants (Etherton \& Bauman, 1998).

GH stimulates growth throughout the body through activation of the GH receptor (GHR). The GHR activates several signal transduction pathways, such as Janus kinase 2 (JAK2) and signal transducers and activators of transcription (STAT5). The activation of these pathways promotes changes in cellular metabolism, differentiation, and transcription of GH-activated genes (Piwien-Pilipuk et al., 2002). In particular, GH stimulates the production and secretion of insulin-like growth factor-1 (IGF-I) by the liver (Wilde et al., 1995). The direct action of IGF-I on target tissues affects cell metabolism, proliferation, and survival (Etherton \& Bauman, 1998; Campbell et al., 
1991). In the mammary gland, IGF-I improves cell survival and increases protein synthesis in the mammary epithelial cell (MEC) (McGuire et al., 1992). However, the actions of IGF-I are mediated by insulin-like growth factor binding proteins (IGFBP). There are several isoforms of IGFBP that have been described (IGFBP-1to -6) (Knight, 2000). IGFBP serve many functions and expression levels differ between isoforms and stage of the gland: development, lactation, or involution (Baumrucker \& Erondu, 2000; Marshman \& Streuli, 2002). The major function of IGFBP is to bind IGF. Through interactions with extracellular matrix proteins, cellular membrane proteins, and proteases, IGFBP regulate the localization and availability of IGF to its receptor (Marshman \& Streuli, 2002; Le Roith et al., 2001).

It is well established that GH increases the production of IGF-I by the liver and that IGF-I can act on many cell types, including MEC, resulting in increased milk production. But, despite the well defined indirect action of GH on the mammary gland, the discovery of the GHR on the mammary epithelium led to the investigation of a direct action of GH on MEC (Plath-Gabler et al., 2001; Sakamoto et al., 2005; Hauser et al., 1990). A bovine derived mammary epithelial cell line, MAC-T, was shown to express the GHR (Zhou et al., 2008). When the GHR and STAT5 were over-expressed, MAC-T cells responded to treatment with GH by increasing mRNA levels of major milk proteins (Zhou et al., 2008). Additionally, it was observed that native MAC-T responded to treatment with GH resulting in an increase in mRNA levels of major milk proteins and altered lipid distribution (Johnson et al., 2010). Previous research has also shown the proteome of native MAC-T cells is altered in response to treatment with GH. GH induced changes in metabolic, cytoskeletal, and other proteins in differentiated MAC-T 
cells (Johnson, 2010). These observations indicate the possibility of a direct action of GH on MEC.

Although MAC-T cells were originally derived from normal bovine mammary tissue, they were immortalized with the simian virus 40 large $\mathrm{T}$ antigen (SV40), which inhibits the ability of p53 and retinoblastoma protein to regulate cell division (Huynh et al., 1991). Due to these known changes in cell cycle regulation, and the potential for changes to other regulatory mechanisms to have also been affected by SV40, the use of models which may more closely resemble conditions in vivo may better represent the response of MEC to $\mathrm{GH}$.

Mammary explants from several species have been widely used to study the mammary gland (Keys et al., 1992; Sheehy et al., 2004; Brennan et al., 2008). Explants retain the structure and orientation of the tissue in culture and preserve interactions between the stroma and epithelium (Sheehy et al., 2004; Keys et al., 1997). However, mammary explants retain the surrounding stromal tissue in the gland and are not a homogenous cell population. Due to the multiple cell types present, explants may not accurately represent the response of the MEC, but rather the complex intercellular interactions of the gland as a whole.

To further segregate the direct effect of GH on MEC, primary MEC can be isolated and used to evaluate their response. Primary cells have previously been used to study the metabolic functions and gene expression of the mammary gland (Suard et al., 1983; Matitashvili \& Bauman, 1999; Wheeler et al., 1995). However, primary MEC are difficult and costly to obtain due to the invasive nature of sampling tissue from a lactating gland. In addition, proliferation rates are limited and cultures often require complex 
substrata (Ip \& Darcy, 1996). Limited proliferation of MEC impedes achieving adequate cell numbers for analysis and substrata can interfere with downstream protein analyses. Primary MEC are also shed into milk and can be isolated from a raw milk sample, and it has previously been shown that MEC in milk are viable (Taylor-Papadimitriou et al., 1977; Stoker \& Perryman, 1984; Ceriani et al., 1979; Buehring, 1990). Transcript levels from mammary tissue and MEC from milk have previously been compared and found to be highly correlated (Boutinaud et al., 2002; Murrieta et al., 2006). They may provide a MEC model that is non-invasive and easy to collect.

Here, we compare the response of several MEC models to GH: explants, primary cells from tissue, and primary cells from milk. To assess the potential of in vitro models to reflect differences between breed, models originating from two major dairy breeds, Holstein and Jersey, were studied. 


\section{$\underline{\text { Methods }}$}

All procedures involving animals were reviewed and approved by California Polytechnic State University, San Luis Obispo's Institutional Animal Care and Use Committee. Neomycin, enzymes in the collagenase cocktail, and metal mesh filters were obtained from Fisher Scientific (Pittsburg, PA). Fetal bovine serum (FBS) was obtained from Innovative Research (Novi, MI).All other materials were obtained from Sigma Aldrich (St. Louis, MO) unless otherwise noted.

\section{Primary Cell Isolation}

Primary mammary cell isolation procedures were modified from earlier published reports (Ebner et al., 1961; Matitashvili \& Bauman, 1999; Richards et al., 1983). Mammary tissue (200-300 g) was collected from multiparous (2nd lactation), lactating dairy cows (Jersey: $190 \mathrm{~d}$ in milk (DIM); Holstein: 125 DIM) immediately post mortem and placed in sterile saline with $1 \%$ penicillin-streptomycin-neomycin and $1 \%$ amphotericin B solution. Excised tissue was washed in Dulbecco's Modified Eagle Medium: Nutrient Mixture F-12 (DME:F12) with $1.25 \%$ penicillin-streptomycinneomycin and $1.25 \%$ amphotericin $\mathrm{B}$ and minced into $3-5 \mathrm{~mm}^{3}$ pieces. Tissue was digested with a collagenase cocktail (DME:F12, 1\% penicillin-streptomycin-neomycin, $1 \%$ amphotericin $\mathrm{B}, 1 \mathrm{mg} / \mathrm{mL}$ collagenase, $0.5 \mathrm{mg} / \mathrm{mL}$ hyaluronidase, $1 \mathrm{U} / \mathrm{mL}$ elastase, $20 \mu \mathrm{g} / \mathrm{mL}$ DNAse) for $2.5 \mathrm{~h}$ at $30^{\circ} \mathrm{C}$. The cell suspension was filtered through three sterile metal mesh filters of decreasing size $(380 \mu \mathrm{m}, 230 \mu \mathrm{m}, 100 \mu \mathrm{m})$; and tissue remaining on the filters was digested for an additional $2.5 \mathrm{~h}$ in fresh collagenase cocktail and filtered again. Following filtration, the cell suspension was washed by centrifugation (5 min, $1000 \mathrm{~g}, 15^{\circ} \mathrm{C}$ ) in Wash 1 (DME:F12 with $1 \%$ penicillin-streptomycin-neomycin, 
$1 \%$ amphotericin $\mathrm{B}, 5 \% \mathrm{FBS}$ and $40 \mu \mathrm{g} / \mathrm{mL}$ DNAse) until the supernatant was clear. The pellet was resuspended in Wash 1 and loaded atop a 3-step Ficoll-BSA gradient (5\%, $10 \%, 15 \%$ BSA in Ficoll $)$ and centrifuged $\left(1 \mathrm{~h}, 1420 \mathrm{~g}, 15^{\circ} \mathrm{C}\right)$ with no brake. The epithelial cell band (Figure 1) was removed and washed 3 times by centrifugation ( $5 \mathrm{~min}$, $1000 \mathrm{~g}, 15^{\circ} \mathrm{C}$ ) in Wash 2 (DME:F12 with $1 \%$ penicillin-streptomycin-neomycin, $1 \%$ amphotericin B, 5\% FBS). Each wash step consisted of resuspending the pellet in $50 \mathrm{~mL}$ of Wash 2, centrifuging, and discarding the supernatant. Purified epithelial cells were cryopreserved in $1 \mathrm{~mL}$ aliquots $\left(\sim 6 \times 10^{6}\right.$ cells/vial) of freezing media with DMSO. Cells were initially stored for $24 \mathrm{~h}$ at $-80^{\circ} \mathrm{C}$ and then transferred to liquid nitrogen for long term storage.

\section{MEC Isolation from Milk}

To isolate mammary epithelial cells from milk, raw milk $(800 \mathrm{~mL})$ was collected

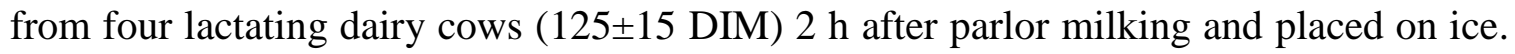
$0.5 \mathrm{mM}$ EDTA was added and raw milk was centrifuged at 500g for 20 minutes. The cream layer and supernatant were discarded. The remaining pellets were pooled by resuspension in $1 \mathrm{X}$ PBS with $1 \%$ penicillin-streptomycin and $0.5 \mathrm{mM}$ EDTA and then passed through a 100uM cell strainer. The pooled cell suspension was washed 3 times in 1X PBS-penicillin-streptomycin by centrifugation $\left(10 \mathrm{~min}, 500 \mathrm{~g}, 4^{\circ} \mathrm{C}\right)$; after each wash, the supernatant was discarded and the pellet resuspended. Finally, the pellet was resuspended in $10 \mathrm{~mL}$ DMEM with 1\% penicillin-streptomycin and layered on top of a 3step Ficoll-BSA gradient $(5 \%, 10 \%, 15 \%$ BSA in Ficoll) and centrifuged $(1 \mathrm{~h}, 1420 \mathrm{~g}$, $15^{\circ} \mathrm{C}$ ) with no brake. The epithelial cell band (Figure 1) was removed and washed 3 times in DMEM with $1 \%$ penicillin-streptomycin. Each wash step consisted of 
resuspending the pellet in 50mL of DMEM with $1 \%$ penicillin-streptomycin, centrifuging (5 min, $1000 \mathrm{~g}, 15^{\circ} \mathrm{C}$ ), and discarding the supernatant. Purified epithelial cells were cultured immediately.

\section{Explant Culture}

Explants were obtained at the same time as tissue for primary cell isolation. Tissue was rinsed in a solution containing 49\% DME:F12, 49\% Hanks' buffered saline solution, $1 \%$ penicillin-streptomycin-neomycin and $1 \%$ amphotericin $\mathrm{B}$ and cut into $1 \mathrm{~mm}^{3}$ pieces. $10-15$ pieces of tissue were transferred to Falcon tubes containing DMEM with $10 \% \mathrm{FBS}, 1 \%$ penicillin-streptomycin, $5 \mu \mathrm{g} / \mathrm{mL}$ porcine insulin, $5 \mu \mathrm{g} / \mathrm{mL}$ ovine prolactin, $1 \mu \mathrm{g} / \mathrm{mL}$ dexamethasone with $0 \mathrm{ng} / \mathrm{mL}$ or $10 \mathrm{ng} / \mathrm{mL} \mathrm{GH}$ and cultured for $12 \mathrm{~h}$ at $37^{\circ} \mathrm{C}$ with $5 \% \mathrm{CO} 2$.

\section{Primary Cell Culture}

Prior to seeding, plates were coated with $10 \mu \mathrm{g}$ of bovine collagen per $\mathrm{cm}^{2}$ of growth area (Santa Cruz Biotechnology, Paso Robles, CA) diluted in 0.01M HCl. The collagen was allowed to incubate at room temperature for 1-2 $\mathrm{h}$. The plates were rinsed three times with $1 \mathrm{X}$ PBS prior to seeding. Primary cells were then cultured on collagencoated 6-well plates in M199:NCTC 135 with 12\% FBS, 1\% penicillin-streptomycin, 1\% amphotericin B, $5 \mu \mathrm{g} / \mathrm{mL}$ porcine insulin, $1 \mu \mathrm{g} / \mathrm{mL}$ progesterone, $1 \mu \mathrm{g} / \mathrm{mL}$ dexamethasone, $5 \mu \mathrm{g} / \mathrm{mL}$ bovine transferrin, $5 \mu \mathrm{M}$ ascorbic acid, $5 \mathrm{mM}$ sodium acetate (INS/PROG) at $37^{\circ} \mathrm{C}$ with $5 \% \mathrm{CO}_{2}$. At $75-80 \%$ confluence, media was changed to M199:NCTC 135 with $12 \%$ fetal bovine serum (FBS), $1 \%$ penicillin-streptomycin, $1 \%$ amphotericin B, $5 \mu \mathrm{g} / \mathrm{mL}$ porcine insulin, $5 \mu \mathrm{g} / \mathrm{mL}$ ovine prolactin, $1 \mu \mathrm{g} / \mathrm{mL}$ dexamethasone, $5 \mu \mathrm{g} / \mathrm{mL}$ bovine transferrin, $5 \mu \mathrm{M}$ ascorbic acid, $5 \mathrm{mM}$ sodium acetate 
with $0 \mathrm{ng} / \mathrm{mL}(\mathrm{DIP})$ or $10 \mathrm{ng} / \mathrm{mL}$ GH $(\mathbf{D I P + G H})$. Primary cells were cultured for the duration indicated in Figures 5, 6, 8 and 9.

\section{Culture of MEC from Milk}

Milk epithelial cells were cultured on collagen-coated wells $\left(10 \mathrm{ug} / \mathrm{cm}^{2}\right)$, prepared as described above, in M199:NCTC 135 with 12\% FBS, 1\% penicillin-streptomycin, 1\% amphotericin B, $5 \mu \mathrm{g} / \mathrm{mL}$ porcine insulin, $1 \mu \mathrm{g} / \mathrm{mL}$ progesterone, $1 \mu \mathrm{g} / \mathrm{mL}$ dexamethasone, $5 \mu \mathrm{g} / \mathrm{mL}$ bovine transferrin, $5 \mu \mathrm{M}$ ascorbic acid, $5 \mathrm{mM}$ sodium acetate (INS/PROG) at $37^{\circ} \mathrm{C}$ with $5 \% \mathrm{CO}$. At $75-80 \%$ confluence, media was changed to M199:NCTC 135 with 12\% FBS, 1\% penicillin-streptomycin, $1 \%$ amphotericin B, 5 $\mu \mathrm{g} / \mathrm{mL}$ porcine insulin, $5 \mu \mathrm{g} / \mathrm{mL}$ ovine prolactin, $1 \mu \mathrm{g} / \mathrm{mL}$ dexamethasone, $5 \mu \mathrm{g} / \mathrm{mL}$ bovine transferrin, $5 \mu \mathrm{M}$ ascorbic acid, $5 \mathrm{mM}$ sodium acetate with $0 \mathrm{ng} / \mathrm{mL}$ (DIP) or 10 ng/mL GH (DIP+GH). Cells were cultured for the durations listed in Figures 7, 10, and 11.

\section{Immunocytochemistry}

Isolated primary cells were stained with an anti-type II cytokeratin antibody to confirm epithelial origin. Type II cytokeratins are intermediate filaments of the intracytoplasmic skeleton (Alberts et al., 2008). All steps were performed at room temperature. At $60 \%$ confluence, cells were fixed for 30 minutes with $4 \%$ formalin in PBS with $0.1 \%$ Triton X100. Cells were blocked for 20 minutes with $10 \%$ FBS in PBS and then incubated with a mouse anti-cytokeratin (type II) antibody (sc-57004, Santa Cruz Biotechnology, Santa Cruz, CA) for 1 hour on a plate rotator. A fluorescein isothiocyanate (FITC)-conjugated goat anti-mouse IgG secondary antibody was used for visualization (sc-2010, Santa Cruz Biotechnology). Nuclei were stained with propidium 
iodide (PI) (Santa Cruz Biotechnology). Cells were visualized using an upright microscope with appropriate filters. FITC and PI images were then overlaid using Adobe Photoshop CS3.

\section{Flow Cytometry}

Cryopreserved primary cells were thawed and immediately fixed for 15 minutes at room temperature using $0.01 \%$ formaldehyde in PBS. Permeabilizing solution (PBS with $0.5 \%$ Tween 20) was added and cells were incubated at room temperature for 15 minutes. An additional volume of permeabilizing solution was added and cells were pelleted by centrifugation at $280 \mathrm{~g}$ for 5 minutes. Cells were resuspended in dilution buffer (PBS with 10\% FBS and 1\% sodium azide) and diluted to 500,000 cells/mL. Cells were incubated overnight at $4^{\circ} \mathrm{C}$ with $3 \%$ BSA and primary antibody, mouse anticytokeratin (type II) antibody (sc-57004, Santa Cruz Biotechnology). The cells were then pelleted and resuspended in dilution buffer, followed by incubation with $3 \%$ BSA and the secondary FITC-conjugated goat anti-mouse IgG secondary antibody (sc-2010, Santa Cruz Biotechnology) overnight at $4^{\circ} \mathrm{C}$. Cells were then pelleted and washed twice with ice cold dilution buffer. Fluorescently labeled cells were quantified using a Guava EasyCyte flow cytometer (Millipore, Billerica, MA).

\section{RNA Extraction and cDNA synthesis}

Total RNA was extracted from all tissue and cell cultures using the RNeasy kit according to the manufacturer's instructions (Qiagen, Valencia, CA). Up to $1 \mu \mathrm{g}$ of total RNA was reverse transcribed using the IScript Kit (Bio-Rad, Hercules, CA) according the manufacturer's instructions. 


\section{Quantitative PCR}

The relative abundance of $\alpha_{\mathrm{S1}}$-casein, $\alpha$-lactalbumin, GH receptor, IGF-I, and IGFBP-3 mRNA transcripts was determined with quantitative PCR using Fast SYBR Green Master mix (Applied Biosystems, Foster City, CA). For primer sequence and

design, see Table A. Quantitative PCR was analyzed using the $2^{-\Delta \Delta \mathrm{C}_{\mathrm{T}}}$ method (Livak \& Schmittgen, 2001) with mRNA transcripts of 18S RNA (18S), $\beta$-actin (ACTB), TATAbinding protein (TBP), or RNA polymerase I, polypeptide D (POLRD1) serving as internal controls.

\section{Statistical Analysis}

For explants and primary cells, tissue was collected from one Holstein cow (125 DIM) and one Jersey cow (190 DIM). For milk derived MEC, milk from four cows was pooled (125 \pm 15 DIM). Each experiment was carried out in triplicate. Normalized data were analyzed using the general linear model in SAS 9.0 (SAS Institute, Inc., Cary, NC). Differences were considered significant at $P<0.05$. Data are represented as the mean \pm SEM. 


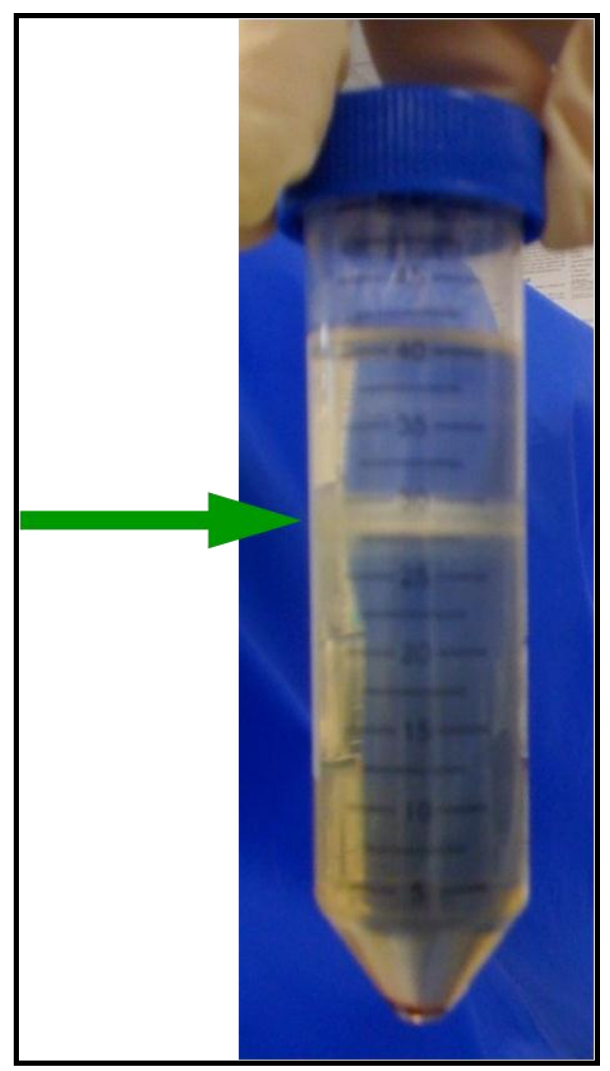

Figure 1: MEC band at the interface of media and $5 \%$ BSA-Ficoll layers.

MEC were isolated from either digested mammary tissue or raw milk using a 3-step BSA-Ficoll density gradient $(5 \%, 10 \%, 15 \%$ layers). Cell suspensions were layered on the top of the 5\% BSA-Ficoll gradient layer and centrifuged. Cell types separated according to density and a heavy band of epithelial cells is visible at the interface of the media layer and 5\%BSA-Ficoll layer, as indicated by the green arrow. 


\begin{tabular}{llll} 
Target & Sense Primer $\left(\mathbf{5}^{\prime} \mathbf{- 3} \mathbf{3}\right)$ & Antisense Primer (5'-3') & Source* $^{*}$ \\
\hline LALBA & AAAGACGACCAGAACCCTCA & GCTTTATGGGCCAACCAGTA & Zhou et al., 2008 \\
CSN1S1 & AATCCATGCCCAACAGAAAG & TCAGAGCCAATGGGATTAGG & Zhou et al., 2008 \\
GHR & CTAACTAGCAATGGCGGT & GGGTGGATCTGGTTGTACTA & Johnson et al., 2010 \\
IGF-I & TCACATCCTCCTCGCATCTCTTCT & AACTGGAGAGCATCCACCAACTCA & BC126802.1 \\
IGFBP3 & AAAGAGATGTTTGAAATGCCTAGTTTT & TCAAACTCGGTTTCACTGACTACTG & Voge et al, 2004 \\
18S & GTAACCCGTTGAACCCCATT & CCATCCAATCGGTAGTAGCG & Zhou et al., 2008 \\
ACTB & GCGTGGCTACAGCTTCACC & TTGATGTCACGGACGATTTC & Bionaz and Loor, 2007 \\
TBP & TGAAACGACTTAGCAGCAGCAGCA & TGCTCGGCTCTGTGGGTTATCTTT & BC113308.1 \\
POLRD1 & GCCCGCACGCTTCGAGGCAT & GTCCCAGCCGCCTGGACCAT & NM_001076144.1 \\
\hline
\end{tabular}

Table A: Primers based on bovine mRNA sequences used for quantitative PCR in this study.

Primers used for quantitative PCR analysis of gene expression in mammary epithelial cells cultured with 0 or $10 \mathrm{ng} / \mathrm{mL}$ GH. * Primers were obtained based on sequences reported in the reference listed, or were designed and analyzed using Primerquest Software (Integrated DNA Technologies, Coralville, IA) and NetPrimer (Premier Biosoft International, Palo Alto, CA) based on the GenBank accession numbers listed. 


\section{$\underline{\text { Results }}$}

Isolated cells were confirmed to be epithelial using immunocytochemistry (Figure 2) and flow cytometry. Cultured cells were stained using a monoclonal cytokeratin type II antibody. Cell populations in culture predominately stained positive for cytokeratin type II indicating their epithelial origin. Additionally, primary cell isolates were quantified as $53 \%$ and $58 \%$ positive for cytokeratin (Jersey and Holstein respectively) by flow cytometry (Figure 3, Table B)

\section{Explants}

Mammary explants from a lactating Jersey cow showed an increase in $\alpha$ lactalbumin mRNA abundance in response to $\mathrm{GH}(P<0.05)$, however, no other targets measured were affected at $12 \mathrm{~h}$ by treatment with $\mathrm{GH}$ (Figure 4).

\section{Primary cells}

Primary cells from both breeds responded to classical lactogenic media through continued expression of milk protein genes. Primary cells isolated from Jersey mammary tissue showed few changes in response to GH. GHR mRNA abundance was increased in response to $\mathrm{GH}$ when measured at 2 and $7 \mathrm{~d}(P<0.05)$, but no difference was observed at $4 \mathrm{~d}$ (Figure 5 and Figure 9). The abundance of milk protein mRNA, $\alpha$-lactalbumin and $\alpha_{\mathrm{s} 1}$-casein, did not change in response to GH. However, a noteworthy trend occurred in IGFBP-3 mRNA expression. The mRNA abundance of IGFBP-3 tended to increase between d 2 and d 4 of treatment, however, this difference was not significant.

After $7 \mathrm{~d}$, primary cells isolated from Holstein mammary tissue did not show a significant difference in the mRNA abundance of any target measured (Figure 6). However, a shorter treatment duration, $4 \mathrm{~d}$, showed a decrease in IGFBP-3 mRNA 
abundance in response to $\mathrm{GH}$, as seen in Figure 8, but no other targets were affected. After $4 \mathrm{~d}$ of treatment with GH, IGFBP-3 mRNA abundance was significantly decreased in comparison to cells not treated with $\mathrm{GH}(P<0.05)$ (Figure 8). Although not significant, a similar trend was also observed at $2 \mathrm{~d}$ of treatment $(P<0.1)$.

\section{MEC from Milk}

MEC isolated from milk showed a limited response to GH. In cells from Holstein milk, an increase in $\alpha$-lactalbumin mRNA abundance was observed in response to $\mathrm{GH}$ $(P<0.05)$. The increase in $\alpha_{\mathrm{s} 1}$-casein mRNA, although not statistically significant, exhibited changes similar to what was previously observed in MAC-T cells. Johnson et al. observed an increase in $\alpha_{\mathrm{s} 1}$-casein mRNA in differentiated MAC-T cells, compared to undifferentiated, and between MAC-T differentiated with $\mathrm{GH}$, compared to those differentiated without. GHR mRNA abundance was significantly increased at $7 \mathrm{~d}$ in Holstein milk cells cultured in lactogenic media when compared to cells cultured in growth media $(P<0.05)$ but was not affected by treatment with GH (Figure 7). Additionally, a decrease in IGFBP-3 mRNA abundance in response to GH was observed at day 4 (Figure 10). This pattern was also observed in Holstein primary cells (Figure 8). MEC from Jersey milk showed no changes in mRNA abundance of any target measured in response to $\mathrm{GH}$. However, a similar trend in IGFBP-3 mRNA abundance was observed between Jersey primary cells and MEC from Jersey milk-IGFBP-3 mRNA abundance was increased at day 4 in response to GH (Figure 9and 11). 


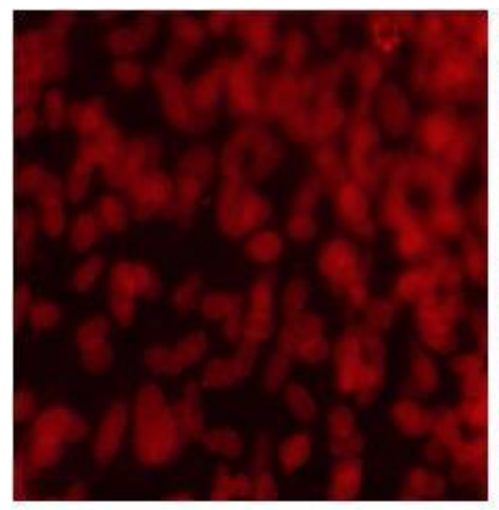

A

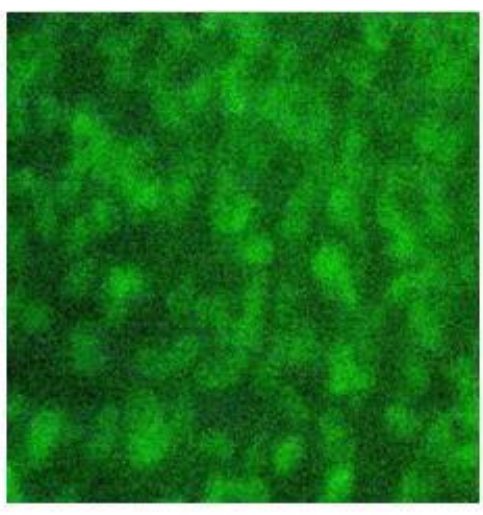

B

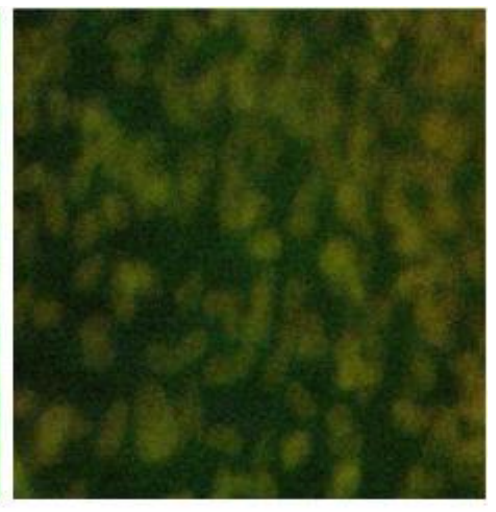

C

Figure 2: Isolated cells are of epithelial origin.

Immunocytochemistry showed cultured cells to be predominately positive for cytokeratin expression, indicating their epitheliality. Images are representative of immunocytochemistry performed on isolated MEC. Panel A shows nuclei stained with propidium iodide; panel B shows cells positive for cytokeratin type II stained using FITC; panel C shows the two images over-layed using Adobe Photoshop. 


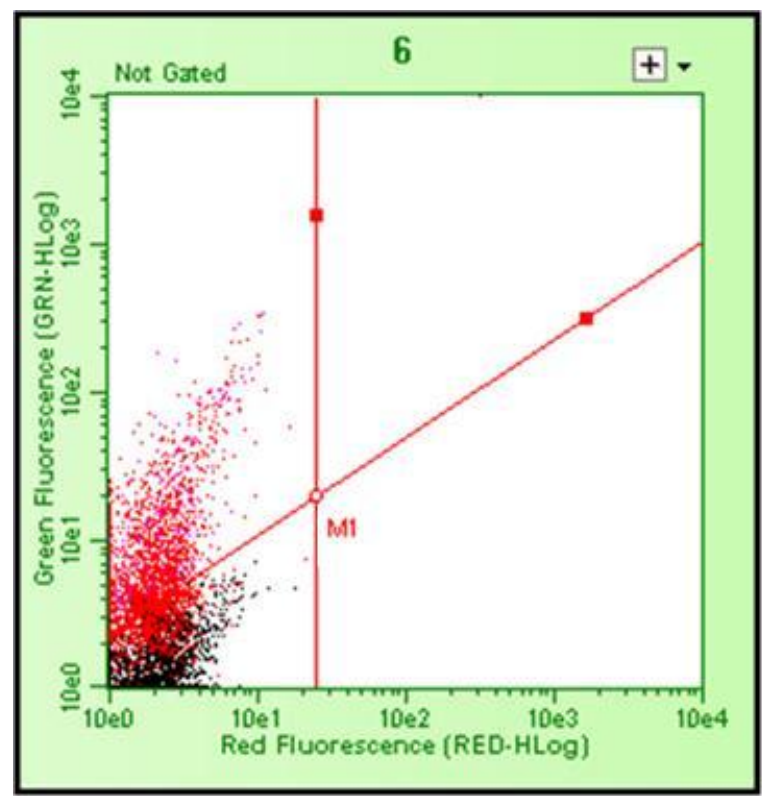

A

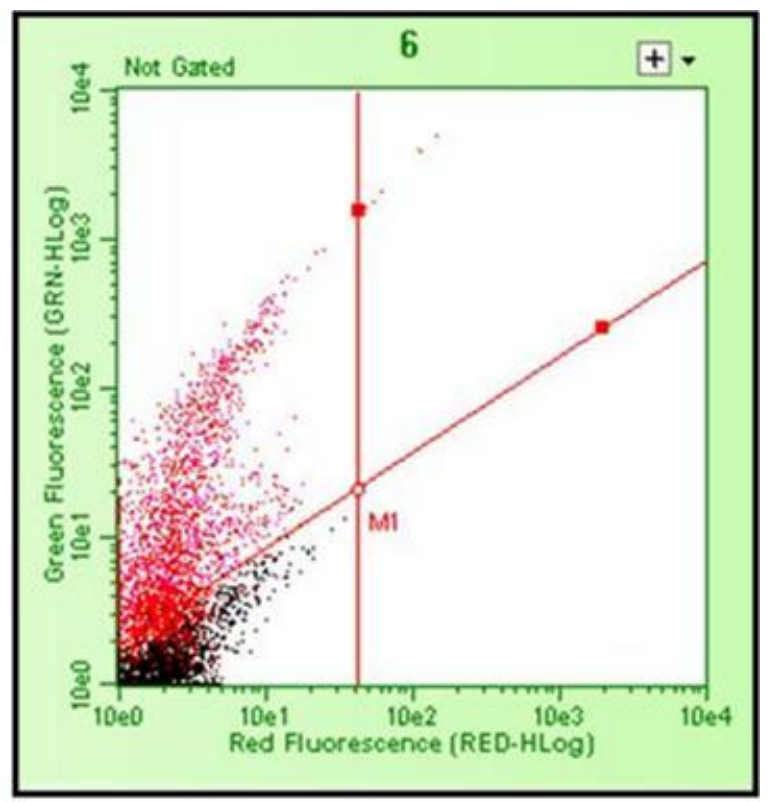

B

Figure 3: Isolated cells are positive for epithelial marker proteins.

Primary MEC were stained with a primary antibody against cytokeratin type II and a FITC-conjugated secondary antibody, then quantified using flow cytometry (A: Jersey, B: Holstein). Gates were set relative to control samples (cells only incubated with secondary antibody). Unstained cells are represented by black dots (control); cells stained with fluorescent antibody against cytokeratins (type II) are represented by red dots (stained). Quantified results are displayed in Table B. 


\begin{tabular}{cccccc}
\multirow{2nyyyn}{*}{ Source } & Sample & $\begin{array}{c}\text { Lower left } \\
\text { quadrant }\end{array}$ & $\begin{array}{c}\text { Upper left } \\
\text { quadrant }\end{array}$ & Total & \% positive \\
\hline \multirow{2}{*}{ Jersey } & control & 4000 & 0 & 4000 & 0 \\
\cline { 2 - 5 } & stained & 1782 & 2218 & 4000 & 55.45 \\
\hline \multirow{2}{*}{ Holstein } & control & 3986 & 14 & 4000 & 0.35 \\
\cline { 2 - 5 } & stained & 1661 & 2339 & 4000 & 58.48 \\
\hline
\end{tabular}

Table B: Primary MEC flow cytometry values.

Primary cells were stained with an antibody against cytokeratin type II and a FITC conjugated antibody. Cells were quantified using flow cytometry. Four individual samples were tested. Counts were compiled into the represented values. 

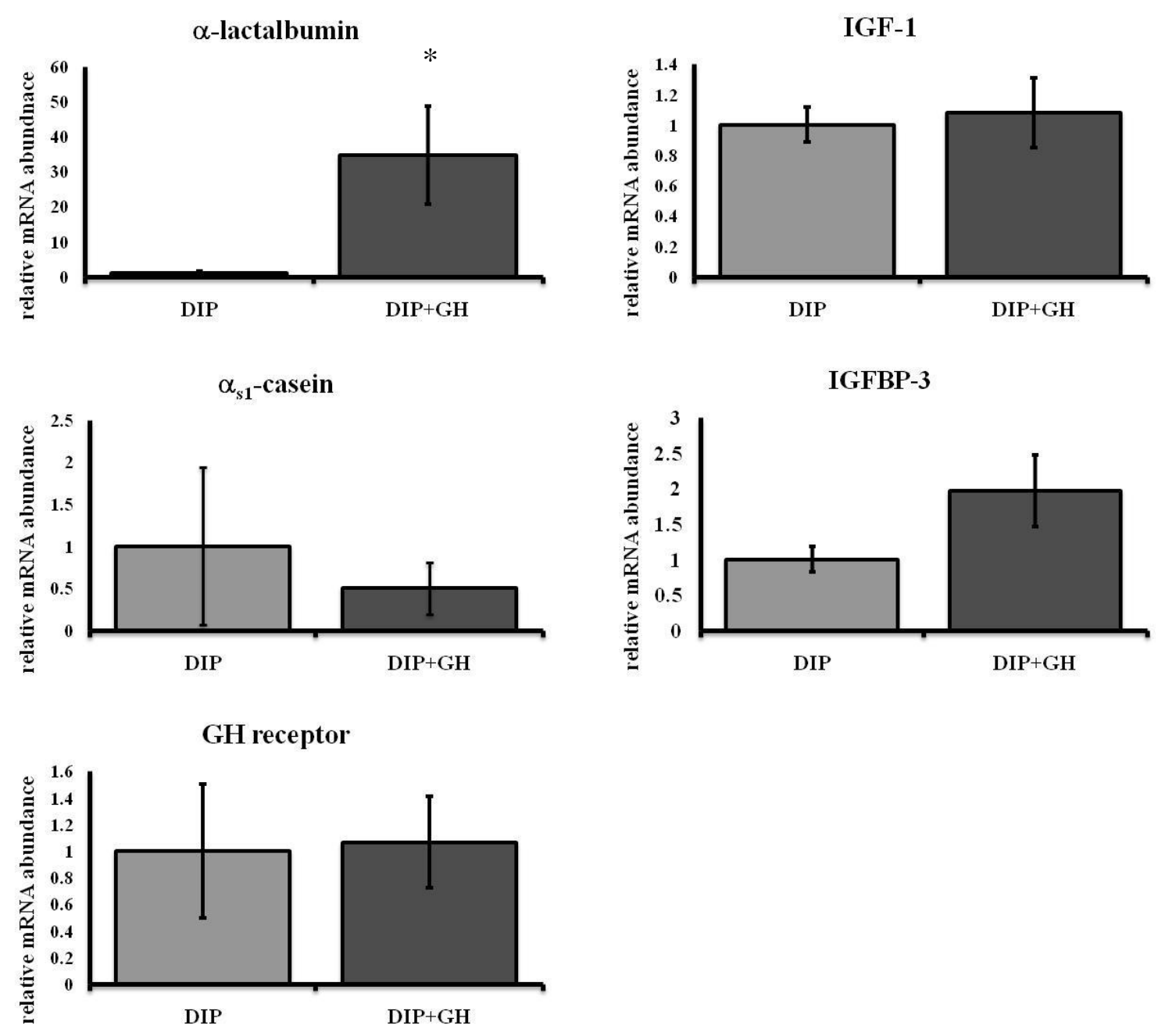

Figure 4: $\alpha$-lactalbumin mRNA abundance in Jersey mammary explants is increased after $12 \mathrm{~h}$ in response to $\mathrm{GH}$.

Mammary explants from a lactating Jersey cow show a limited response to GH, with only the mRNA abundance of $\alpha$-lactalbumin being affected by GH. Explants taken from lactating mammary tissue from a Jersey cow were cultured for $12 \mathrm{~h}$ in DMEM with $10 \%$ FBS, $1 \%$ penicillin-streptomycin, $5 \mu \mathrm{g} / \mathrm{mL}$ porcine insulin, $5 \mu \mathrm{g} / \mathrm{mL}$ ovine prolactin, 1 $\mu \mathrm{g} / \mathrm{mL}$ dexamethasone with $0 \mathrm{ng} / \mathrm{mL} \mathrm{GH}$ (DIP) or $10 \mathrm{ng} / \mathrm{mL} \mathrm{GH}$ (DIP+GH) and cultured for $12 \mathrm{hrs}$ at $37^{\circ} \mathrm{C}$ with $5 \% \mathrm{CO}_{2}$. Total RNA was extracted and reverse transcribed. Targets were analyzed using quantitative PCR. Bars represent the mean \pm SEM. An asterisk $(*)$ denotes a significant difference $(P<0.05)$. 
$\alpha$-lactalbumin

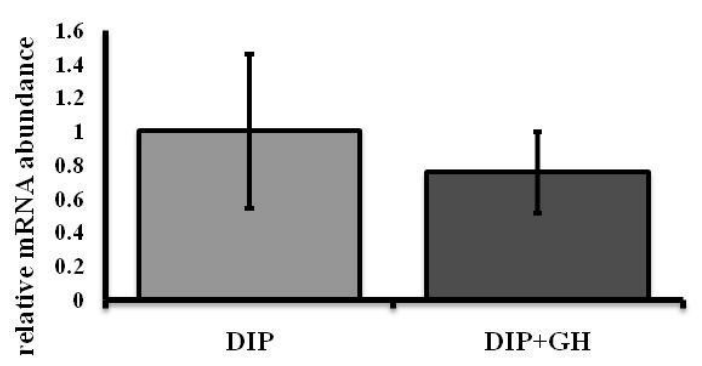

$\alpha_{s 1}$-casein

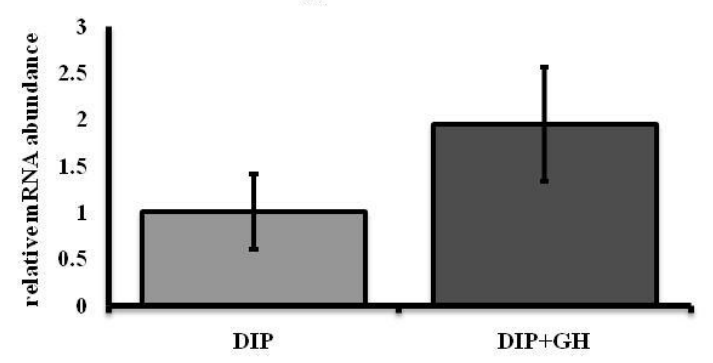

GH receptor

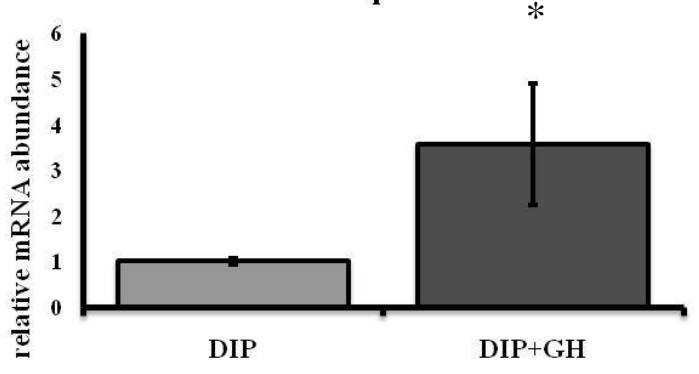

IGF-1

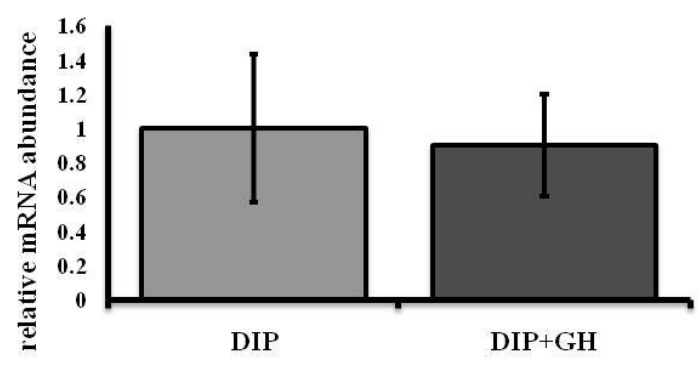

IGFBP-3

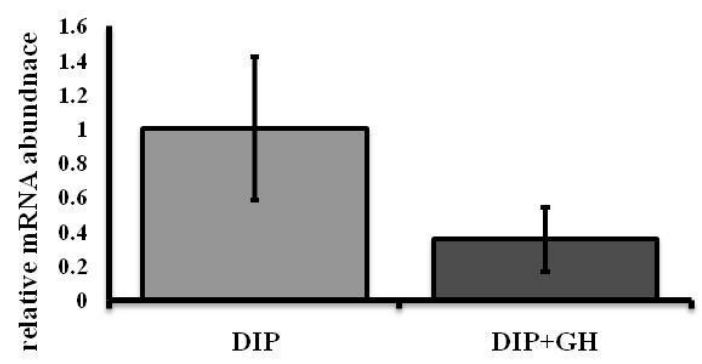

Figure 5: In primary MEC from a Jersey cow, GHR mRNA abundance is increased in response to $\mathrm{GH}$ after $7 \mathrm{~d}$.

Primary MEC from a Jersey cow show an increase in GHR mRNA abundance after 7d in response to treatment with GH. Confluent primary MEC isolated from lactating Jersey mammary tissue were cultured for $7 \mathrm{~d}$ in M199:NCTC 135 with 12\% FBS, $1 \%$ penicillinstreptomycin, $1 \%$ amphotericin B, $5 \mu \mathrm{g} / \mathrm{mL}$ porcine insulin, $5 \mu \mathrm{g} / \mathrm{mL}$ ovine prolactin, 1 $\mu \mathrm{g} / \mathrm{mL}$ dexamethasone, $5 \mu \mathrm{g} / \mathrm{mL}$ bovine transferrin, $5 \mu \mathrm{M}$ ascorbic acid, $5 \mathrm{mM}$ sodium acetate with $0 \mathrm{ng} / \mathrm{mL}(\mathbf{D I P})$ or $10 \mathrm{ng} / \mathrm{mL} \mathrm{GH}(\mathbf{D I P}+\mathbf{G H})$ at $37^{\circ} \mathrm{C}$ with $5 \% \mathrm{CO}_{2}$. Total RNA was extracted and reverse transcribed. Targets were analyzed using quantitative PCR. Bars represent the mean \pm SEM. An asterisk $(*)$ denotes a significant difference $(P<0.05)$. 
$\alpha$-lactalbumin

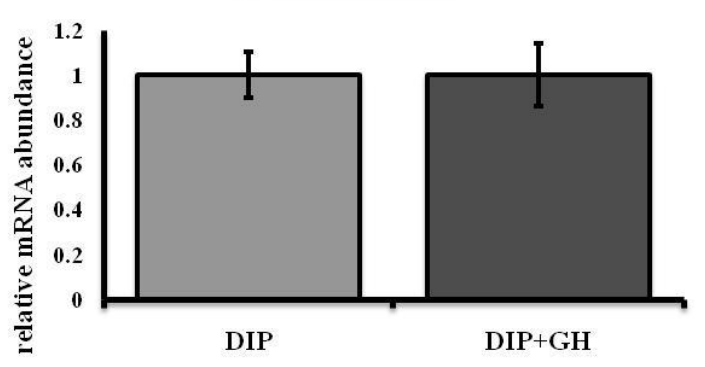

$\alpha_{s 1}$-casein

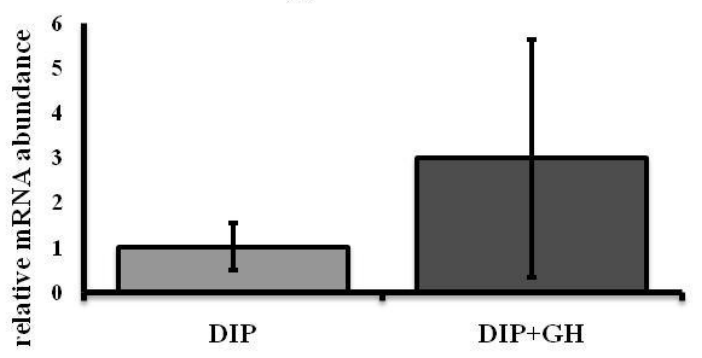

GH receptor

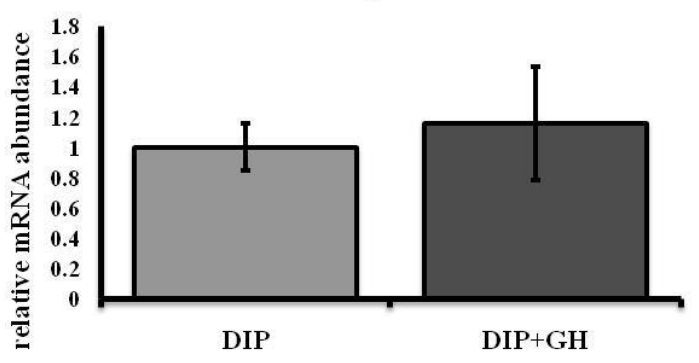

IGF-1

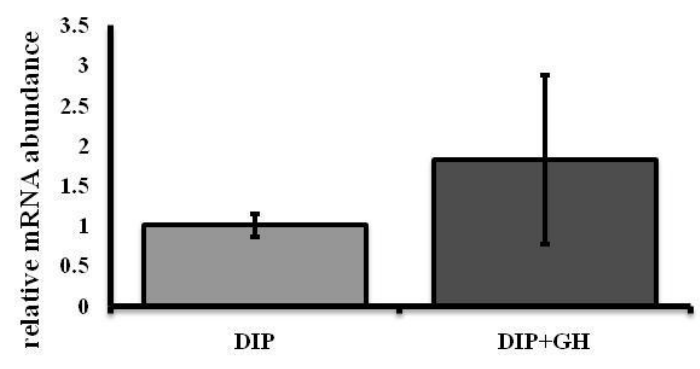

IGFBP-3

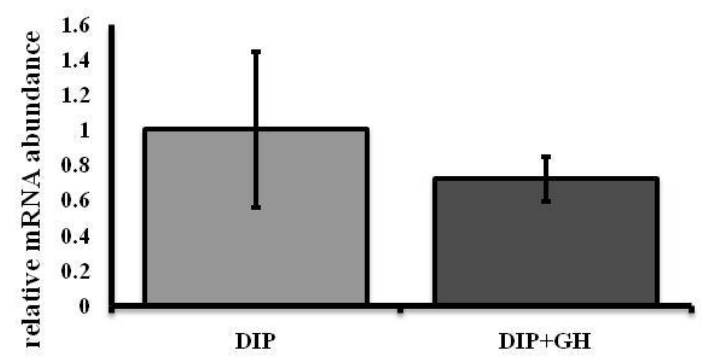

Figure 6: Primary MEC from a Holstein do not respond to treatment with GH after 7 d.

No change in the mRNA abundance of targets in primary MEC from Holstein mammary tissue was observed after $7 \mathrm{~d}$ in response to $\mathrm{GH}$. Confluent primary MEC isolated from lactating Holstein mammary tissue were cultured for $7 \mathrm{~d}$ in M199:NCTC 135 with 12\% FBS, $1 \%$ penicillin-streptomycin, $1 \%$ amphotericin $\mathrm{B}, 5 \mu \mathrm{g} / \mathrm{mL}$ porcine insulin, $5 \mu \mathrm{g} / \mathrm{mL}$ ovine prolactin, $1 \mu \mathrm{g} / \mathrm{mL}$ dexamethasone, $5 \mu \mathrm{g} / \mathrm{mL}$ bovine transferrin, $5 \mu \mathrm{M}$ ascorbic acid, $5 \mathrm{mM}$ sodium acetate with $0 \mathrm{ng} / \mathrm{mL}$ (DIP) or $10 \mathrm{ng} / \mathrm{mL} \mathrm{GH}(\mathbf{D I P + G H})$ at $37^{\circ} \mathrm{C}$ with $5 \% \mathrm{CO}_{2}$. Total RNA was extracted and reverse transcribed. Targets were analyzed using quantitative PCR. Bars represent the mean \pm SEM. 
$\alpha$-lactalbumin

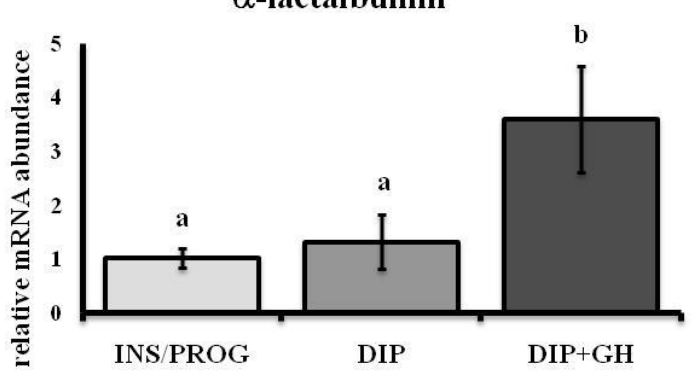

$\alpha_{s 1}$-casein

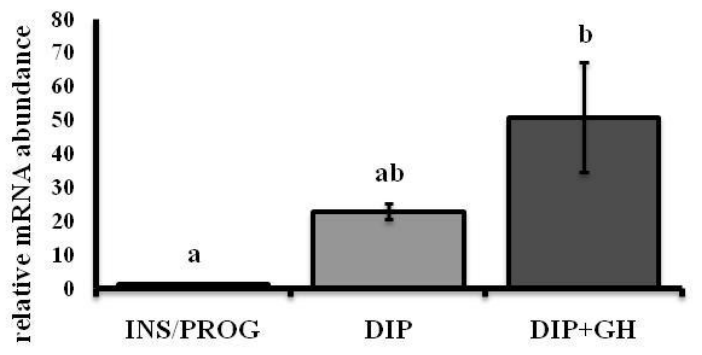

GH receptor

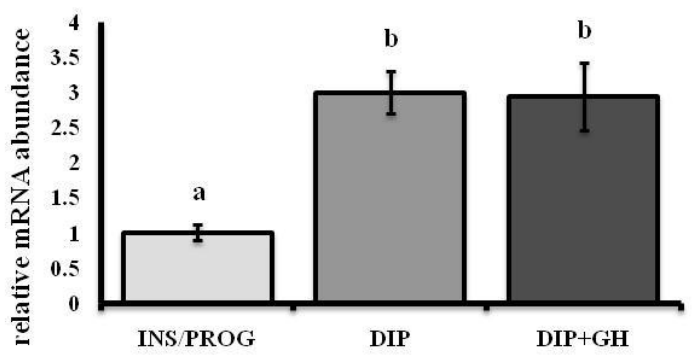

IGF-1

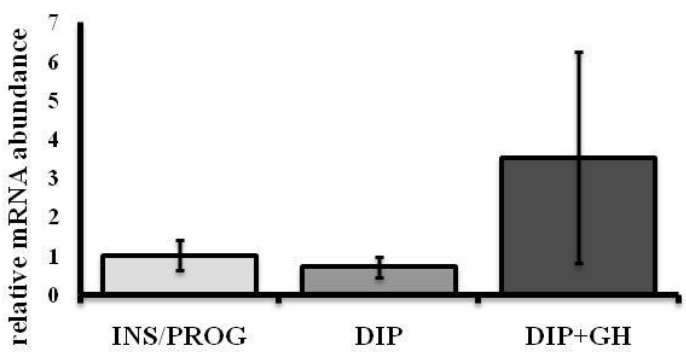

IGFBP-3

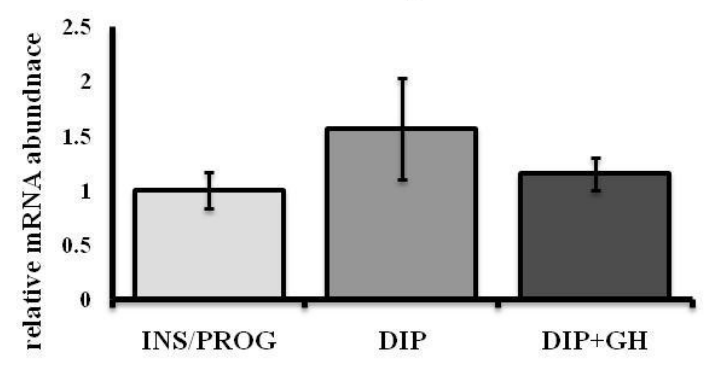

Figure 7: In MEC from Holstein milk, $\alpha$-lactalbumin mRNA abundance is increased in response to treatment with $\mathrm{GH}$ after $7 \mathrm{~d}$.

Abundance of $\alpha$-lactalbumin mRNA in MEC from Holstein milk cultured with GH was increased after $7 \mathrm{~d}$ in culture. Additionally, $\alpha_{\mathrm{s} 1}$-casein mRNA abundance was greater in MEC differentiated with GH, than undifferentiated MEC. GHR mRNA abundance was greater in differentiated MEC. MEC isolated from milk were cultured in M199:NCTC 135 with $12 \% \mathrm{FBS}, 1 \%$ penicillin-streptomycin, $1 \%$ amphotericin $\mathrm{B}, 5 \mu \mathrm{g} / \mathrm{mL}$ porcine insulin, $1 \mu \mathrm{g} / \mathrm{mL}$ progesterone, $1 \mu \mathrm{g} / \mathrm{mL}$ dexamethasone, $5 \mu \mathrm{g} / \mathrm{mL}$ bovine transferrin, 5 $\mu \mathrm{M}$ ascorbic acid, $5 \mathrm{mM}$ sodium acetate (INS/PROG) until confluent. At 75-80\% confluence, media was changed to M199:NCTC 135 with $12 \%$ FBS, $1 \%$ penicillinstreptomycin, $1 \%$ amphotericin $\mathrm{B}, 5 \mu \mathrm{g} / \mathrm{mL}$ porcine insulin, $5 \mu \mathrm{g} / \mathrm{mL}$ ovine prolactin, 1 $\mu \mathrm{g} / \mathrm{mL}$ dexamethasone, $5 \mu \mathrm{g} / \mathrm{mL}$ bovine transferrin, $5 \mu \mathrm{M}$ ascorbic acid, $5 \mathrm{mM}$ sodium acetate with $0 \mathrm{ng} / \mathrm{mL}$ (DIP) or $10 \mathrm{ng} / \mathrm{mL} \mathrm{GH}(\mathbf{D I P}+\mathbf{G H})$ and cultured for $7 \mathrm{~d}$. Total RNA was extracted and reverse transcribed. Targets were analyzed using quantitative PCR. Bars represent the mean \pm SEM. A superscript denotes a significant difference $(P<0.05)$. 

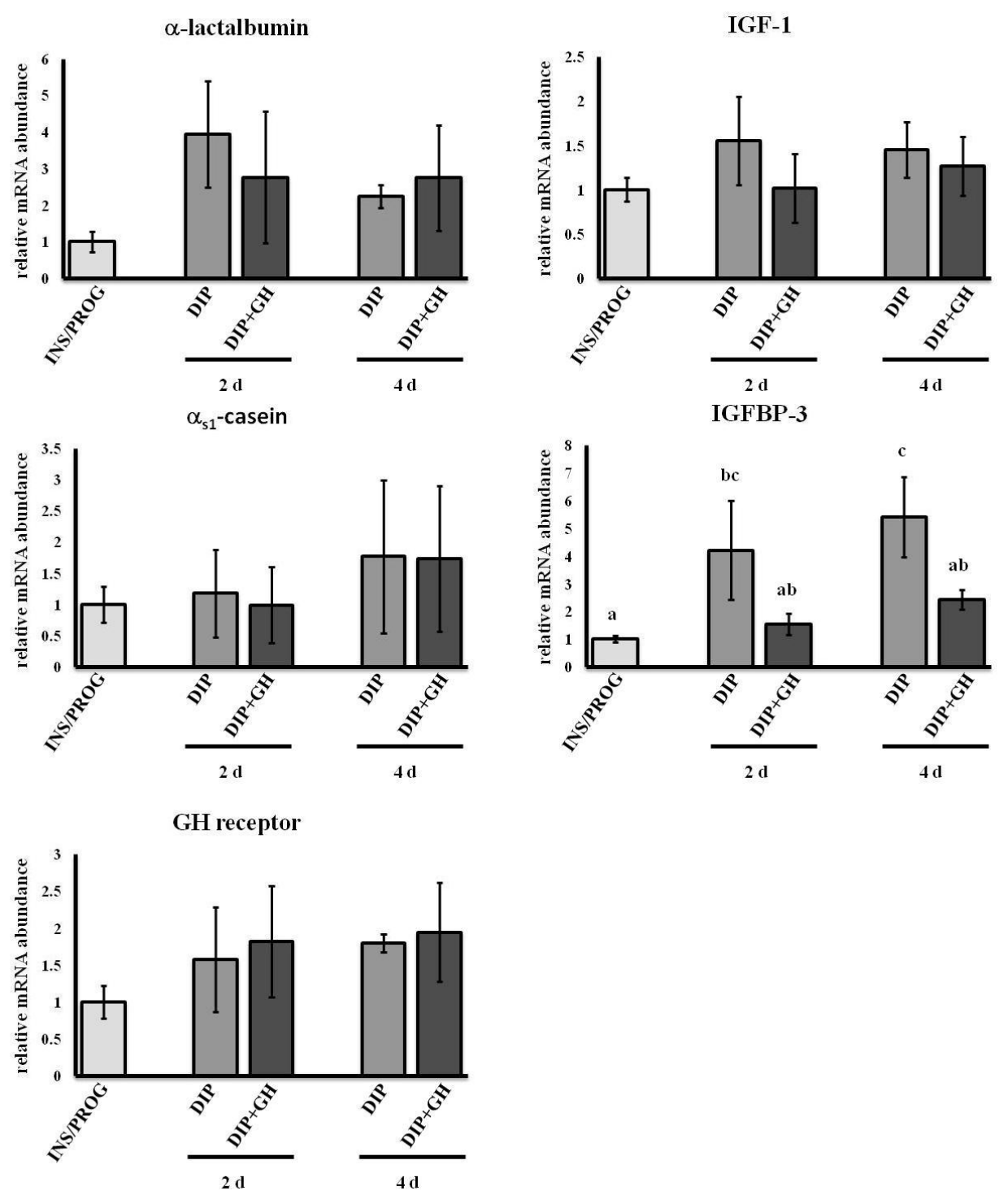

Figure 8: Primary Holstein MEC have decreased IGFBP-3 mRNA abundance after $4 \mathrm{~d}$ of treatment with $\mathrm{GH}$.

Primary MEC from a Holstein cow responded to GH with a decrease in mRNA abundance of IGFBP-3 after $4 \mathrm{~d}$; a similar pattern is also seen after $2 \mathrm{~d}$, although not statistically significant. MEC isolated from Holstein mammary tissue were cultured in M199:NCTC 135 with 12\% FBS, $1 \%$ penicillin-streptomycin, $1 \%$ amphotericin B, 5 $\mu \mathrm{g} / \mathrm{mL}$ porcine insulin, $1 \mu \mathrm{g} / \mathrm{mL}$ progesterone, $1 \mu \mathrm{g} / \mathrm{mL}$ dexamethasone, $5 \mu \mathrm{g} / \mathrm{mL}$ bovine transferrin, $5 \mu \mathrm{M}$ ascorbic acid, $5 \mathrm{mM}$ sodium acetate (INS/PROG) until confluent. At 75-80\% confluence, media was changed to M199:NCTC 135 with 12\% FBS, $1 \%$ penicillin-streptomycin, $1 \%$ amphotericin $\mathrm{B}, 5 \mu \mathrm{g} / \mathrm{mL}$ porcine insulin, $5 \mu \mathrm{g} / \mathrm{mL}$ ovine prolactin, $1 \mu \mathrm{g} / \mathrm{mL}$ dexamethasone, $5 \mu \mathrm{g} / \mathrm{mL}$ bovine transferrin, $5 \mu \mathrm{M}$ ascorbic acid, 5 $\mathrm{mM}$ sodium acetate with $0 \mathrm{ng} / \mathrm{mL}$ (DIP) or $10 \mathrm{ng} / \mathrm{mL} \mathrm{GH}$ (DIP+GH) and cultured for 2 and $4 \mathrm{~d}$. Total RNA was extracted and reverse transcribed. Targets were analyzed using quantitative PCR. Bars represent the mean \pm SEM. A superscript denotes a significant difference $(P<0.05)$ 
$\alpha-$ lactalbumin

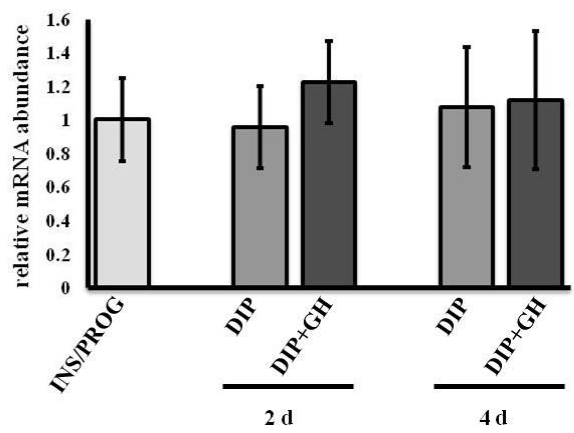

$\alpha_{\mathrm{s} 1}$-casein
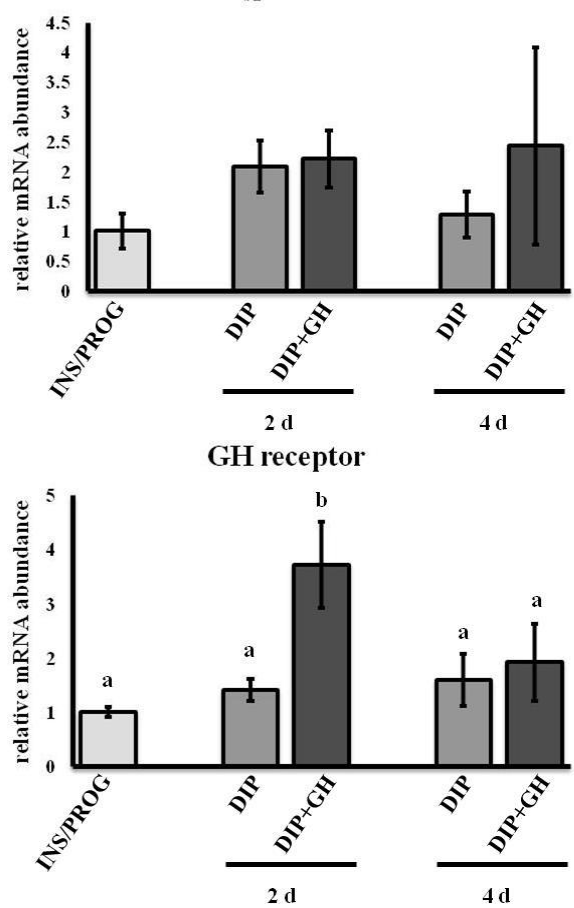

IGF-1

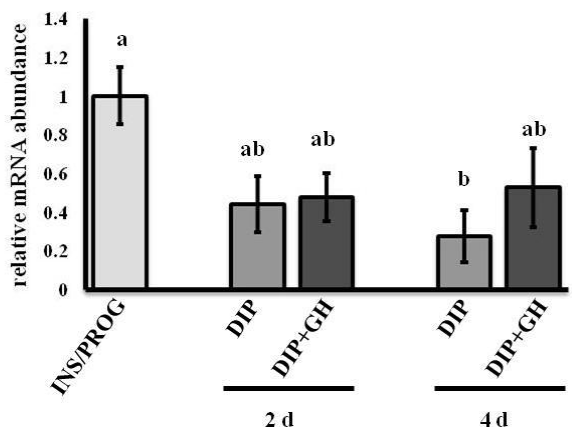

IGFBP-3

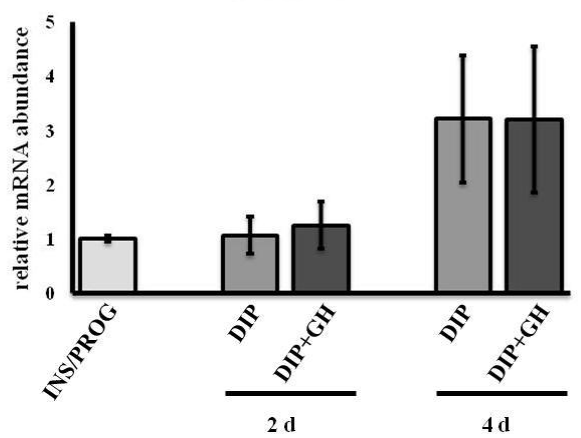

Figure 9: Primary Jersey MEC have increased GHR mRNA abundance after 2 d in response to treatment with $\mathbf{G H}$.

GHR mRNA abundance was significantly greater in MEC after $2 \mathrm{~d}$ in response to treatment with GH. No other targets were affected by GH. MEC isolated from mammary tissue from a Jersey cow were cultured in M199:NCTC 135 with 12\% FBS, $1 \%$ penicillin-streptomycin, $1 \%$ amphotericin $\mathrm{B}, 5 \mu \mathrm{g} / \mathrm{mL}$ porcine insulin, $1 \mu \mathrm{g} / \mathrm{mL}$ progesterone, $1 \mu \mathrm{g} / \mathrm{mL}$ dexamethasone, $5 \mu \mathrm{g} / \mathrm{mL}$ bovine transferrin, $5 \mu \mathrm{M}$ ascorbic acid, $5 \mathrm{mM}$ sodium acetate (INS/PROG). At $75-80 \%$ confluence, media was changed M199:NCTC 135 with 12\% FBS, $1 \%$ penicillin-streptomycin, $1 \%$ amphotericin B, 5 $\mu \mathrm{g} / \mathrm{mL}$ porcine insulin, $5 \mu \mathrm{g} / \mathrm{mL}$ ovine prolactin, $1 \mu \mathrm{g} / \mathrm{mL}$ dexamethasone, $5 \mu \mathrm{g} / \mathrm{mL}$ bovine transferrin, $5 \mu \mathrm{M}$ ascorbic acid, $5 \mathrm{mM}$ sodium acetate with $0 \mathrm{ng} / \mathrm{mL}$ (DIP) or 10 $\mathrm{ng} / \mathrm{mL}$ GH (DIP+GH) and cultured for 2 and $4 \mathrm{~d}$. Total RNA was extracted and reverse transcribed. Targets were analyzed using quantitative PCR. Bars represent the mean \pm SEM. A superscript denotes a significant difference $(P<0.05)$. 
$\alpha$-lactalbumin

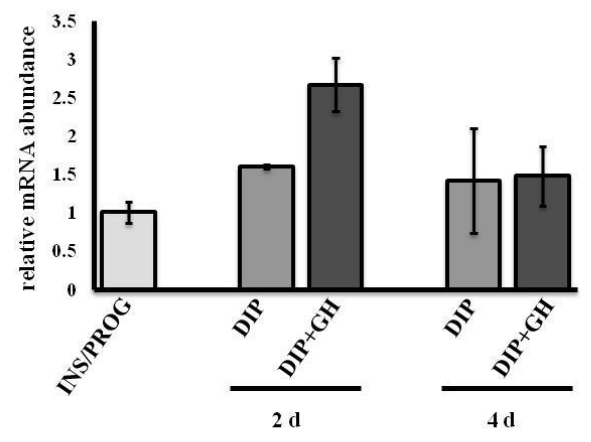

$\alpha_{s 1}$-casein

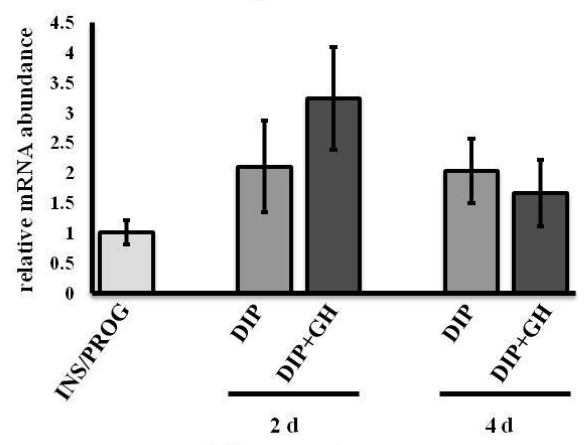

GH receptor

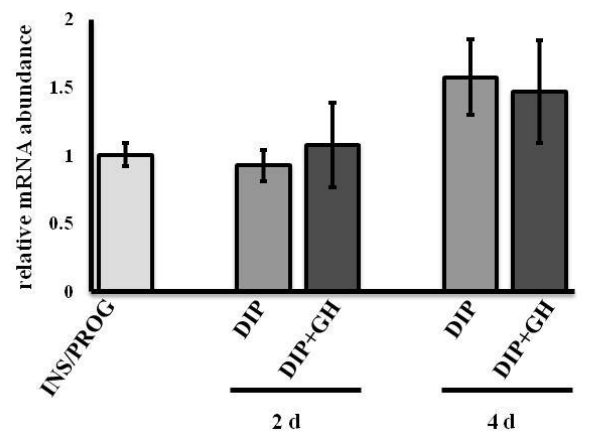

IGF-1

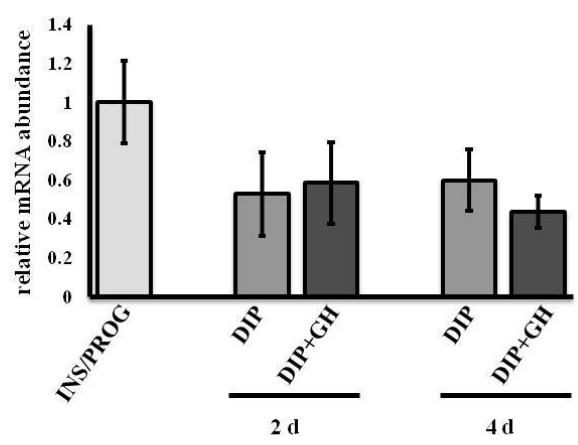

IGFBP-3

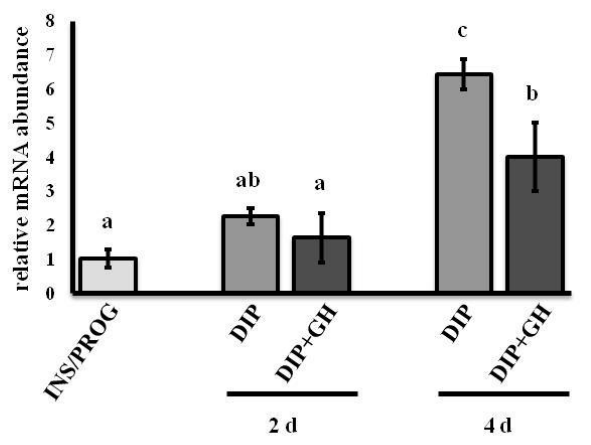

Figure 10: Holstein MEC from milk have decreased mRNA abundance of IGFBP-3 after $4 \mathrm{~d}$ in response to treatment with $\mathrm{GH}$.

IGFBP-3 mRNA abundance is decreased in MEC from Holstein milk after $4 \mathrm{~d}$ in response to treatment with GH. No other targets were affected by GH. MEC isolated from Holstein milk were cultured in M199:NCTC 135 with 12\% FBS, 1\% penicillinstreptomycin, $1 \%$ amphotericin $\mathrm{B}, 5 \mu \mathrm{g} / \mathrm{mL}$ porcine insulin, $1 \mu \mathrm{g} / \mathrm{mL}$ progesterone, $1 \mu \mathrm{g} / \mathrm{mL}$ dexamethasone, $5 \mu \mathrm{g} / \mathrm{mL}$ bovine transferrin, $5 \mu \mathrm{M}$ ascorbic acid, $5 \mathrm{mM}$ sodium acetate (INS/PROG). At 75-80\% confluence, media was changed M199:NCTC 135 with $12 \% \mathrm{FBS}, 1 \%$ penicillin-streptomycin, $1 \%$ amphotericin $\mathrm{B}, 5 \mu \mathrm{g} / \mathrm{mL}$ porcine insulin, $5 \mu \mathrm{g} / \mathrm{mL}$ ovine prolactin, $1 \mu \mathrm{g} / \mathrm{mL}$ dexamethasone, $5 \mu \mathrm{g} / \mathrm{mL}$ bovine transferrin, $5 \mu \mathrm{M}$ ascorbic acid, $5 \mathrm{mM}$ sodium acetate with $0 \mathrm{ng} / \mathrm{mL}$ (DIP) or $10 \mathrm{ng} / \mathrm{mL}$ GH (DIP+GH) and cultured for 2 and $4 \mathrm{~d}$. Total RNA was extracted and reverse transcribed. Targets were analyzed using quantitative PCR. Bars represent the mean \pm SEM. A superscript denotes a significant difference $(P<0.05)$ 

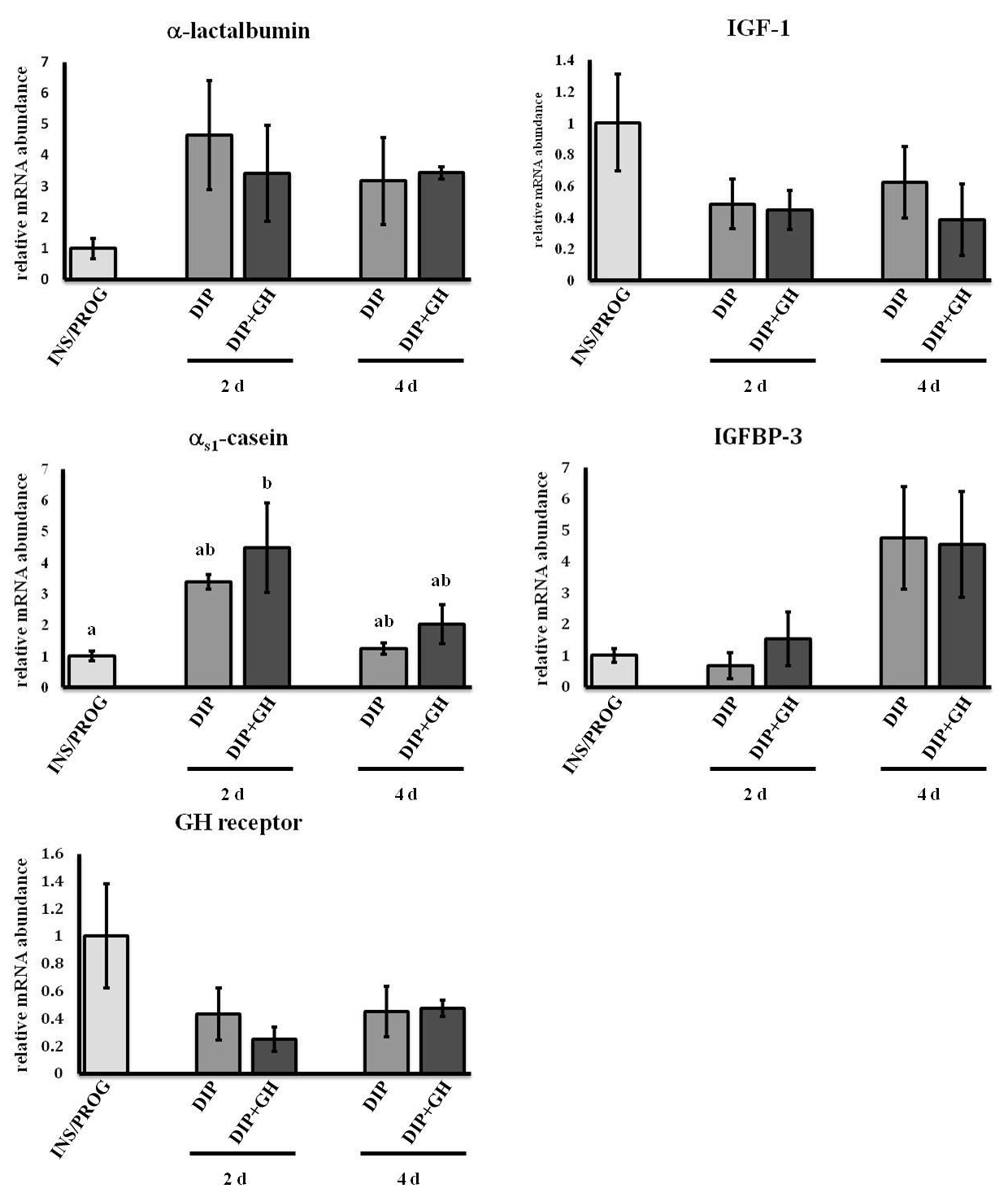

Figure 11: In MEC from Jersey milk, the mRNA abundance for any transcript evaluated was not affected by GH.

Although mRNA transcript abundance was not affected by $\mathrm{GH}, \alpha_{\mathrm{s} 1}$-casein mRNA abundance was greater in MEC differentiated with GH than in undifferentiated MEC after 2 days. MEC isolated from Jersey milk were cultured in M199:NCTC 135 with $12 \% \mathrm{FBS}, 1 \%$ penicillin-streptomycin, $1 \%$ amphotericin $\mathrm{B}, 5 \mu \mathrm{g} / \mathrm{mL}$ porcine insulin, 1 $\mu \mathrm{g} / \mathrm{mL}$ progesterone, $1 \mu \mathrm{g} / \mathrm{mL}$ dexamethasone, $5 \mu \mathrm{g} / \mathrm{mL}$ bovine transferrin, $5 \mu \mathrm{M}$ ascorbic acid, $5 \mathrm{mM}$ sodium acetate (INS/PROG). At 75-80\% confluence, media was changed M199:NCTC 135 with 12\% FBS, 1\% penicillin-streptomycin, 1\% amphotericin $\mathrm{B}, 5 \mu \mathrm{g} / \mathrm{mL}$ porcine insulin, $5 \mu \mathrm{g} / \mathrm{mL}$ ovine prolactin, $1 \mu \mathrm{g} / \mathrm{mL}$ dexamethasone, $5 \mu \mathrm{g} / \mathrm{mL}$ bovine transferrin, $5 \mu \mathrm{M}$ ascorbic acid, $5 \mathrm{mM}$ sodium acetate with $0 \mathrm{ng} / \mathrm{mL}$ (DIP) or 10 $\mathrm{ng} / \mathrm{mL} \mathrm{GH}(\mathrm{DIP}+\mathrm{GH})$ and cultured for 2 and $4 \mathrm{~d}$. Total RNA was extracted and reverse transcribed. Targets were analyzed using quantitative PCR. Bars represent the mean \pm SEM. A superscript denotes a significant difference $(P<0.05)$. 


\section{$\underline{\text { Discussion }}$}

Recently, two studies utilizing MAC-T cells have reported a direct response to GH (Johnson et al., 2010; Zhou et al., 2008). One study utilizing transformed MAC-T cells which over-express the GHR and STAT5 reported a significant increase in the mRNA expression of $\alpha$-lactalbumin and $\alpha_{\mathrm{s} 1}$-casein, and other milk proteins in response to GH (Zhou et al., 2008). GHR mRNA was over-expressed in MAC-T cells because it appeared to be in very low abundance when quantified by a ribonuclease protection assay. Additionally, Johnson et al. reported that native MAC-T cells cultured for $7 \mathrm{~d}$ in lactation media with 0 or $10 \mathrm{ng} / \mathrm{mL} \mathrm{GH}$ showed increased $\alpha$-lactalbumin and $\alpha_{\mathrm{s} 1}$-casein mRNA in response to $\mathrm{GH}$, in addition to increased abundance of the GHR mRNA (Johnson et al., 2010). Prior proteomic work in the MAC-T cell line has shown a direct effect of GH which induced changes in abundance of proteins involved in cytoskeletal arrangement, metabolism and lactogenesis, indicating that GH plays a role in stabilizing the cell and preparing it for lactation (Johnson, 2010). Although MAC-T cells provide a useful model of MEC, undergoing immortalization may have altered their ability to model normal MEC function. Here, the direct effect of GH on MEC was investigated using three primary in vitro MEC models: explants, primary MEC isolated from whole mammary tissue, and primary MEC derived from milk. Mammary explants and primary cells did not express the same response to $\mathrm{GH}$ as previously observed in MAC-T cells. While some primary mammary models showed an increased abundance of milk proteins in response to $\mathrm{GH}$, no model reproduced the robust response to $\mathrm{GH}$ observed in MAC-T cells. 
As previously indicated, in vitro primary cell models provide an isolated cell model of MEC. However, because there is some dispute as to whether MEC themselves express and secrete IGF-I, or if it is only produced by near-by stromal cells, and because the in vivo role of $\mathrm{GH}$ is coupled with IGF-I, the mRNA abundance of IGF-I was investigated to evaluate the influence, if any, IGF-I may play in in vitro mammary models. IGF-I mRNA was found in all models studied. This may be expected in explants because it is well documented that the mammary stroma synthesizes and secretes IGF-I (Kleinberg, 1997; Fleming et al., 2005). However, in isolated populations of MEC, IGF-I mRNA was also detected. It has been previously reported that the mammary epithelium does not express IGF-I mRNA (Campbell, 1988). Zhou et al. reported the expression of IGF-I mRNA in transfected MAC-T; however, its abundance was not affected by treatment with GH (Zhou et al., 2008). Here, IGF-I mRNA was detected in both mammary explants and primary cells, however IGF-I mRNA abundance was not affected by treatment with GH. This indicates the observed changes in IGFBP-3 mRNA abundance are likely a result of a direct action of $\mathrm{GH}$, and not due to the autocrine or paracrine effects of increased IGF-I being secreted in response to $\mathrm{GH}$.

Expression of GHR mRNA was detected in mammary explants and primary cells from tissue and milk. The presence of GHR mRNA supports the possibility of a direct role of GH on MEC; however, that role does not appear to be directly mediating an increase in milk components to the same magnitude observed in MAC-T. Only explants and MEC from Holstein milk showed a significant increase in $\alpha$-lactalbumin in response to $\mathrm{GH}$. Based on these results, and proteomic changes previously observed in the MAC$\mathrm{T}$ cell line, the direct action of GH on the MEC may have influence over differentiation 
and regulate binding proteins to alter the availability of IGF-I, rather than exerting a direct effect on milk synthesis and secretion.

A previous study evaluating the response of Holstein and Jersey cows to GH reported differences in their capacity to respond to GH (West et al., 1990). West et al. reported that in Holsteins as the dose of $\mathrm{GH}$ increased, milk yield increased in a linear fashion in Holsteins; however, in Jerseys, as the dose of GH increased over the same range, milk yield only increased until the dosage of $\mathrm{GH}$ reached $15 \mathrm{mg}$ and then declined at higher doses. A similar difference in breed response is observed in the current results. IGFBP-3 mRNA abundance is altered by GH and the effect differs between breeds. Primary and milk cells from Holsteins showed a decrease in IGFBP-3 mRNA abundance in response to $\mathrm{GH}$ after $4 \mathrm{~d}$. In both primary and milk MEC from Jersey cows, no change was observed in response to $\mathrm{GH}$, however, IGFBP-3 abundance tended to increase from day 2 and day 4 regardless of GH treatment. Changes in the abundance of IGFBP-3 may affect the actions of the GH-IGF axis, because IGFBP-3 is the major binding protein for IGF-I (Baumrucker and Erondu, 2000). For example, mammary epithelial cells isolated from Holsteins may be able to better respond to $\mathrm{GH}$ because $\mathrm{GH}$ inhibits the production of IGFBP-3, allowing more IGF-I to remain unbound and able to interact with its receptor. This proposed model is diagramed in Figure 12.

The roles of IGFBP are not fully understood, however, it is well established that they bind IGF-I, can extend its half-life in serum, limit the availability of IGF-I, can aid in the localization of IGF-I to a particular tissue through interactions with extracellular matrix proteins and membrane proteins. IGFBP also have important IGF-independent actions by binding of extracellular membrane proteins and can induce changes in gene 
expression, metabolism and apoptosis (Marshman \& Streuli, 2002; Gluckman et al., 1987; Baumrucker, 2005; (Yamada and Lee, 2009). As a result, an increase in IGFBP-3 by GH may influence the gene expression of MEC, independently of IGF-I.

The direct effects of GH and MEC are not fully defined; however, these data indicate GH may play a role in regulating the expression of IGFBP-3. Whether the observed changes in IGFBP-3 mRNA abundance are translated into changes in protein has yet to be tested. However, despite the complex relationship of IGFBP-3 with IGF-I and MEC, there is an influence of GH over IGFBP-3 mRNA abundance which substantiates further investigation into the roles and relevance of the relationships between IGFBP-3 and GH and their effects on MEC in vivo. 


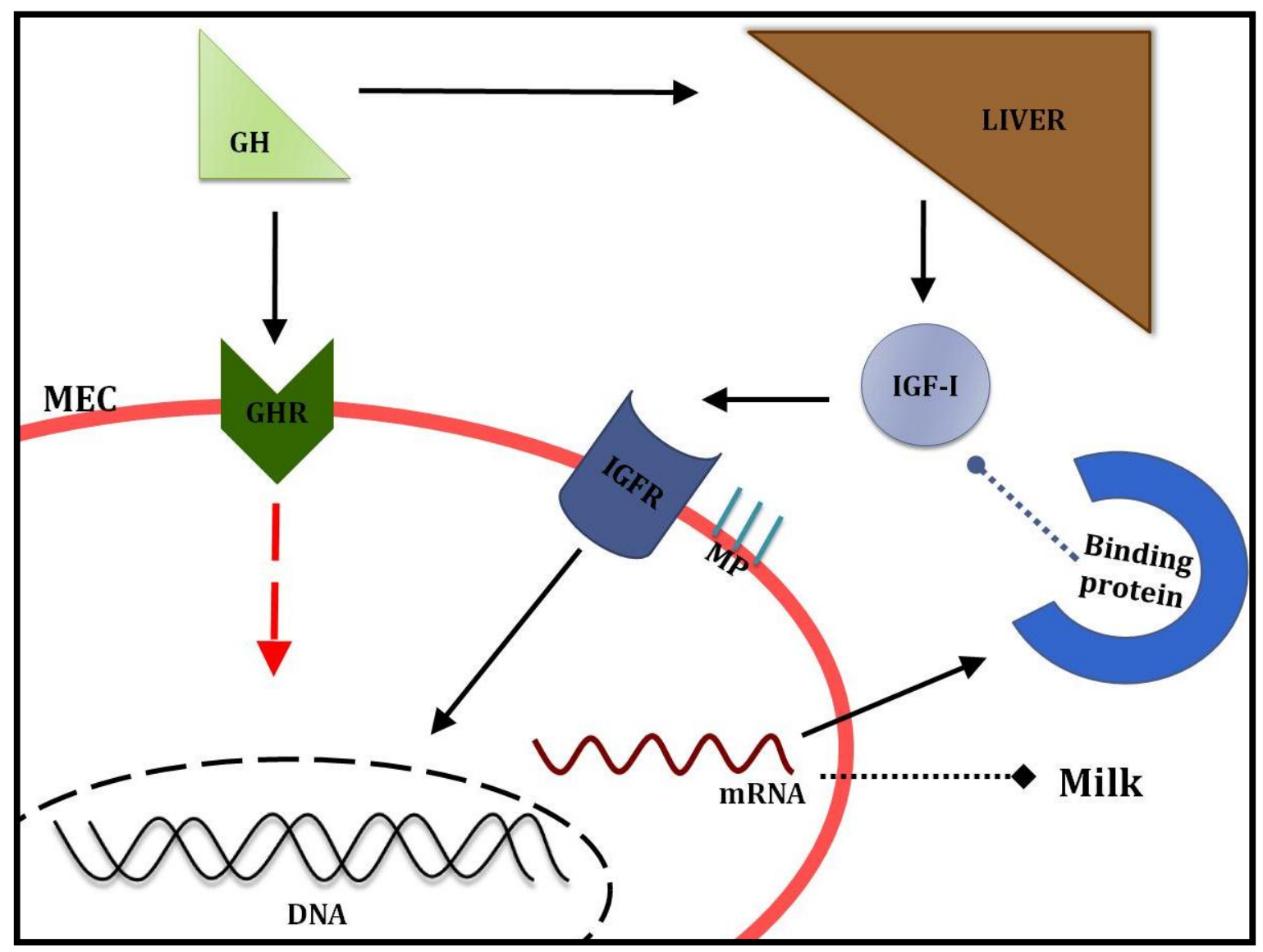

Figure 12: Proposed model of direct effect of GH on primary bovine mammary epithelial cells.

GH stimulates the production of IGF-I by the liver. IGF-I is a potent growth factor which stimulates gene transcription and protein synthesis through its receptor. The direct action of GH on MEC alters the mRNA abundance of IGFBP-3. IGFBP-3 binds IGF-I in circulation, it can sequester it from interacting with its receptor, in addition to aiding in localization to the receptor through interaction with nearby membrane proteins. By regulating IGFBP-3 mRNA abundance, $\mathrm{GH}$ in turn effects the systemic availability of IGF-I. GH: growth hormone, GHR: growth hormone receptor, MEC: mammary epithelial cell, IGF-I: insulin-like growth factor-1, IGFR: insulin-like growth factor-1 receptor, MP: membrane proteins. 


\section{Chapter 3}

\section{LIMITATIONS AND CONCLUSIONS}

\section{$\underline{\text { Limitations and Implications }}$}

Due to culture conditions, the nature of the models utilized, and the limited number of animals available, there are several important factors that limit the depth of inference of these results.

Attempts to culture primary MEC and milk derived MEC without the use of FBS were unsuccessful. Particularly in milk derived MEC, the low number of cells obtained by each isolation made an initial dense seeding impossible. Additionally, these cells did not proliferate at all without the presence of serum and with serum, adequate proliferation took 10-12 days. It has previously been suggested that due to their lack of in vitro proliferation, milk cells must represent a fully differentiated cell type (Boutinaud \& Jammes, 2002). As a result of observing poor growth in milk derived MEC and the wide spread use of serum reported in the literature, primary MEC were always cultured with serum. Even with the addition of serum, primary cells exhibited better proliferation than milk derived cells. Investigation into the requirements of serum for both primary and milk derived MEC may prove useful in designing future experiments.

In addition to limited proliferation without serum, unknown quantities of growth factors and other proteins present in serum represent a confounding variable. Additionally, because GH is present in serum, it is difficult to determine the actual dose of GH during experimentation. However, despite unknown concentrations of GH, serum lots were the same for each experiment. During the course of these experiments, charcoal-stripped serum was not used. In light of these limitations, it may be useful in 
future to evaluate primary cell proliferation with charcoal-filtered serum and use it during future experiments. If primary cells fail to proliferate using charcoal-stripped serum, it may be appropriate to use standard serum during proliferation and charcoal-stripped during experimentation.

Given the concern of the addition of an unquantified amount GH through the use of serum in addition to the treatment concentration of $10 \mathrm{ng} / \mathrm{mL}$, it may also be useful to evaluate a dose-response curve for GH in primary cells. GH concentrations in serum can vary between $4.1-167 \mathrm{ng} / \mathrm{mL}$ (Honn et al., 1975). The treatment value (10ng/mL GH) of GH in this study was selected based on previous dose-response curves in MAC-T and values reported in the literature (Johnson et al., 2010).

Considering the integrated role GH and IGF-I play in vivo, evaluating their synergistic effects on IGFBP-3 in primary MEC would lend clarity to the proposed model and the observed differences between dairy breeds.

MEC populations for these experiments were all derived from the campus dairy herd. For milk-derived cells, milk was pooled from four dairy cows and a total of $800 \mathrm{~mL}$ of milk could be collected at one time. These limitations were a result of the equipment available and feasibility of time. The centrifuge used was capable of holding $800 \mathrm{~mL}$ of contents and the time required to obtain the milk samples became a limiting factor in order to quickly return to the laboratory and begin isolating MEC. As a result, only a small number of MEC were able to be collected at one time. By collecting a larger volume of raw milk, a larger initial population of MEC could be collected with which to begin experiments. Additionally, because milk was collected from a small number of animals, it is difficult to draw inferences that apply to breeds as a whole. 
For explants and primary MEC, only two animals were used for this study (one each of Holstein and Jersey). Because all primary cells from each breed were originally derived from the same animal, it is difficult to extrapolate results obtained from these two individual animals to their respective breed populations as a whole. However, although only one animal was used for the initial isolation, the experiment was replicated three times. Additionally, most cells lines, MAC-T in particular, also originate from cells isolated from one individual. Despite this, MAC-T have been widely used to model bovine MEC in vitro. However, it is common to validate results obtained from cells lines by evaluating primary models. Therefore, in this study using primary cells that have not been widely studied, it would have been valuable to have more individuals from which to obtain samples to aid in reducing the impact that individual variations in genotype, health status, and stage of lactation may play in this model. It is important to note, though, that the pattern of IGFBP-3 abundance in response to GH was similar between MEC from the same breed, regardless of the isolation technique used. Although the sample size in this study was low, different MEC models obtained from different animals showed the same pattern of response to $\mathrm{GH}$ across breeds. This lends support to the claim that $\mathrm{GH}$ has differing effects between Jerseys and Holsteins.

In spite of these limitations, these results remain valuable initial data that can serve to guide future investigations. Future studies utilizing these primary models would benefit from the availability of more sample animals, particularly animals at the same stage of lactation, and perhaps a broader collection of samples beyond the campus herd. Increased sampling would more accurately represent the response of breeds as a whole, and not only the isolated population in the campus herd. 


\section{Conclusion}

In consideration of this study's limitations, further investigation is required in order to convincingly describe the proposed model of the direct effect of $\mathrm{GH}$ and its potential regulation of IGFBP-3. Differences observed between breeds were conserved across all models evaluated, although not at the same magnitude. Additionally, these conclusions have been drawn from mRNA abundance data and it is critical to verify if these differences in mRNA abundance are still present in protein abundance. It is also important to note that there are other regulators of IGFBP-3 in vivo that were not measured here. Investigation into any effect GH may play on other regulators of IGFBP3 may yield a more complete, and accurate, model of the direct role of $\mathrm{GH}$.

The reported results taken with consideration of their limitations provide a useful potential model of the direct role of GH on bovine MEC. Although extrapolation of these results to whole populations is difficult, it provides a plausible explanation of one of the differences between Jersey and Holstein cattle's response to GH. 


\section{$\underline{\text { Literature Cited }}$}

Akers RM 1985 Lactogenic hormones - binding-sites, mammary growth, secretory-cell differentiation, and milk biosynthesis in ruminants. Journal of Dairy Science 68(2) 501-519

Akers RM 2006 Major advances associated with hormone and growth factor regulation of mammary growth and lactation in dairy cows. Journal of Dairy Science 89(4) $1222-1234$

Akers RM, McFadden TB, Purup S, Vestergaard M, Sejrsen K \& Capuco AV 2000 Local IGF-I axis in peripubertal ruminant mammary development. Journal of Mammary Gland Biology and Neoplasia 5(1) 43-51

Alberts B, Johnson A, Lewis J, Raff M, Roberts K \& Walter P 2008 Molecular Biology of the Cell. 5th Edition.: Garland Science, Taylor \& Francis Group, LLC.

Aslakson CJ \& Miller FR 1992 Selective events in the metastatic process defined by analysis of the sequential dissemination of subpopulations of a mouse mammary tumor. Cancer Research 52(6) 1399-1405

Ball RK, Friis RR, Schoenenberger CA, Doppler W \& Groner B 1988 Prolactin regulation of beta-casein gene expression and of a cytosolic $120-\mathrm{kd}$ protein in a cloned mouse mammary epithelial cell line. EMBO J 7(7) 2089-2095

Barclay JL, Kerr LM, Arthur L, Rowland JE, Nelson CN, Ishikawa M, d'Aniello EM, White M, Noakes PG \& Waters MJ 2010 In Vivo Targeting of the Growth Hormone Receptor (GHR) Box1 Sequence Demonstrates that the GHR Does Not Signal Exclusively through JAK2. Molecular Endocrinology 24(1) 204-217

Baserga R, Peruzzi F \& Reiss K 2003 The IGF-1 receptor in cancer biology. 107873 877

Bauman DE \& Currie WB 1980 Partitioning of nutrients during pregnancy and lactation - a review of mechanisms involving homeostasis and homeorhesis. Journal of Dairy Science 63(9) 1514-1529

Bauman DE \& Vernon RG 1993 Effects of exogenous bovine somatotropin on lactation. Annual Review of Nutrition 13 437-461

Baumrucker CR 2005 Intracrine signaling in the mammary gland. Livestock Production Science 98(1-2) 47-56

Baumrucker CR \& Erondu NE 2000 Insulin-like growth factor (IGF) system in the bovine mammary gland and milk. Journal of Mammary Gland Biology and Neoplasia 5(1) 53-64

Baxter F, Neoh K \& Tevendale M 2007 The Beginning of the End: Death Signaling in Early Involution. Journal of Mammary Gland Biology and Neoplasia 12(1) 3-13

Berelowitz M, Szabo M, Frohman LA, Firestone S, Chu L \& Hintz RL 1981 Somatomedin-C Mediates Growth Hormone Negative Feedback by Effects on Both the Hypothalamus and the Pituitary. Science 212(4500) 1279-1281 
Berry SD, McFadden TB, Pearson RE \& Akers RM 2001 A local increase in the mammary IGF-1: IGFBP-3 ratio mediates the mammogenic effects of estrogen and growth hormone. Domestic Animal Endocrinology 21(1) 39-53

Bolander FF 1989 Molecular endocrinology. Academic Press

Boutinaud M, Ben Chedly MH, Delamaire E \& Guinard-Flament J 2008 Milking and feed restriction regulate transcripts of mammary epithelial cells purified from milk. Journal of Dairy Science 91(3) 988-998

Boutinaud M \& Jammes H 2002 Potential uses of milk epithelial cells: a review. Reproduction Nutrition Development 42(2) 133-147

Boutinaud M, Rulquin H, Keisler DH, Djiane J \& Jammes H 2002 Use of somatic cells from goat milk for dynamic studies of gene expression in the mammary gland. Journal of Animal Science 80(5) 1258-1269

Braun JEA \& Severson DL 1992 Regulation of the synthesis, processing and translocation of lipoprotein-lipase. Biochemical Journal 287 337-347

Brennan AJ, Sharp JA, Lefevre CM \& Nicholas KR 2008 Uncoupling the mechanisms that facilitate cell survival in hormone-deprived bovine mammary explants. J Mol Endocrinol 41(3) 103-116

Brisken C, Ayyannan A, Nguyen C, Heineman A, Reinhardt F, Jan T, Dey SK, Dotto GP \& Weinberg RA 2002 IGF-2 Is a Mediator of Prolactin-Induced Morphogenesis in the Breast. Developmental cell 3(6) 877-887

Brisken C \& O'Malley B 2010 Hormone action in the Mammary Gland. Cold Spring Harbor Perspectives in Biology 2

Buehring GC 1990 Culture of mammary epithelial-cells from bovine-milk. Journal of Dairy Science 73(4) 956-963

Butler AA \& Le Roith D 2001 Control of growth by the somatropic axis: Growth hormone and the insulin-like growth factors have related and independent roles. Annual Review of Physiology 63 141-164

Campbell PG 1988 Insulin-like growth factor-I and insulin-like growth factor binding proteins in the bovine mammary gland: Receptors, endogenous secretion, and appearance in milk.

Campbell PG, Skaar TC, Vega JR \& Baumrucker CR 1991 Secretion of insulin-like growth factor-1 (IGF-1) and IGF-binding proteins from bovine mammary tissue in vitro. Journal of Endocrinology 128(2) 219-228

Capper JL, Cady RA \& Bauman DE 2009 Increased production reduces the dairy industry's environmental impact. Proceedings of the 18th Annual Tri-State Dairy Nutrition Conference, Fort Wayne, Indiana, USA, 21-22 April, 2009 71-82

Capper JL, Castaneda-Gutierrez E, Cady RA \& Bauman DE 2008 The environmental impact of recombinant bovine somatotropin (rbST) use in dairy production. Proceedings of the National Academy of Sciences of the United States of America 105(28) 9668-9673 
Carstens GE, Glaser DE, Byers FM, Greene LW \& Lunt DK 1997 Effects of bovine somatotropin treatment and intermittent growth pattern on mammary gland development in heifers. Journal of Animal Science 75(9) 2378-2388

CarterSu C, Schwartz J \& Smit LS 1996 Molecular mechanism of growth hormone action. Annual Review of Physiology 58 187-207

Ceriani R, Taylor-Papadimitriou J, Peterson J \& Brown P 1979 Characterization of cells cultured from early lactation milks. In Vitro Cellular \&amp; Developmental Biology - Plant 15(5) 356-362

Ceriani RL 1974 Hormones and other factors controlling growth in mammary-gland review. Journal of Investigative Dermatology 63(1) 93-108

Cohick WS 1998 Role of the insulin-like growth factors and their binding proteins in lactation. Journal of Dairy Science 81(6) 1769-1777

Cohick WS \& Clemmons DR 1993 The insulin-like growth-factors. Annual Review of Physiology 55 131-153

Cohick WS \& Turner JD 1998 Regulation of IGF binding protein synthesis by a bovine mammary epithelial cell line. Journal of Endocrinology 157(2) 327-336

Collier R, McGrath MF \& Vincini JL 1999 Somatotropin and the U.S. dairy industry. Medecin Veterinaire du Quebec 29(2) 89-92

Cotes P, Crichton J, Folley S \& Young F 1949 Galactopoietic activity of purified anterior pituitary growth hormone. Nature 164(4180) 992-993

Dahl GE, Chapin LT, Allen MS, Moseley WM \& Tucker HA 1991 Comparison of somatotropin and growth hormone-releasing factor on milk-yield, serum hormones, and energy status. Journal of Dairy Science 74(10) 3421-3428

Daniel CW \& Smith GH 1999 The mammary gland: A model for development. Journal of Mammary Gland Biology and Neoplasia 4(1) 3-8

Danielson KG, Oborn CJ, Durban EM, Butel JS \& Medina D 1984 Epithelial mouse mammary cell line exhibiting normal morphogenesis in vivo and functional differentiation in vitro. Proceedings of the National Academy of Sciences 81(12) 3756-3760

Dulbecco R, Bologna M \& Unger M 1979 Differentiation of a rat mammary cell-line in vitro. Proceedings of the National Academy of Sciences of the United States of America 76(3) 1256-1260

Ebner KE, Hoover CR, Hageman EC \& Larson BL 1961 Cultivation and properties of bovine mammary cell cultures. Experimental Cell Research 23(2) 373-385

Eppard PJ, Bentle LA, Violand BN, Ganguli S, Hintz RL, Kung L, Krivi GG \& Lanza GM 1992 Comparison of the galactopoietic response to pituitary-derived and recombinant-derived variants of bovine growth hormone. Journal of Endocrinology 132(1) $47-56$ 
Ernens I, Clegg R, Schneider YJ \& Larondelle Y 2007 Short communication: Ability of cultured mammary epithelial cells in a bicameral system to secrete milk fat. Journal of Dairy Science 90(2) 677-681

Etherton TD \& Bauman DE 1998 Biology of somatotropin in growth and lactation of domestic animals. Physiological Reviews 78(3) 745-761

Fleming JM, Leibowitz BJ, Kerr DE \& Cohick WS 2005 IGF-I differentially regulates IGF-binding protein expression in primary mammary fibroblasts and epithelial cells. Journal of Endocrinology 186(1) 165-178

Flint DJ, Beattie J \& Allan GJ 2003 Modulation of the actions of IGFs by IGFBP-5 in the mammary gland. Hormone and Metabolic Research 35(11-12) 809-815

Flint DJ \& Knight CH 1997 Interactions of prolactin and growth hormone (GH) in the regulation of mammary gland function and epithelial cell survival. Journal of Mammary Gland Biology and Neoplasia 2(1) 41-48

Gaffney EV 1982 A cell-line (HBL-100) established from human-breast milk. Cell and Tissue Research 227(3) 563-568

Gibson CA, Staley MD \& Baumrucker CR 1999 Identification of IGF binding proteins in bovine milk and the demonstration of IGFBP-3 synthesis and release by bovine mammary epithelial cells. Journal of Animal Science 77(6) 1547-1557

Gibson JP, van der Meulen M, McBride BW \& Burton JH 1992 The Effects of Genetic and Phenotypic Production Potential on Response to Recombinant Bovine Somatotropin. Journal of Dairy Science 75(3) 878-884

Glimm DR, Baracos VE \& Kennelly JJ 1990 Molecular evidence for the presence of growth-hormone receptors in the bovine mammary-gland. Journal of Endocrinology 126(3) R5-R8

Gluckman PD, Breier BH \& Davis SR 1987 Physiology of the Somatotropic Axis with Particular Reference to the Ruminant. Journal of Dairy Science 70(2) 442-466

Gorewit RC, Svennersten K, Butler WR \& Uvnasmoberg K 1992 Endocrine responses in cows milked by hand and machine. Journal of Dairy Science 75(2) 443448

Grant DS, Kleinman HK, Leblond CP, Inoue S, Chung AE \& Martin GR 1985 The basement-membrane-like matrix of the mouse ehs tumor .2. Immunohistochemical quantitation of 6 of its components. American Journal of Anatomy 174(4) 387-398

Hauser SD, McGrath MF, Collier RJ \& Krivi GG 1990 Cloning and in vivo expression of bovine growth-hormone receptor messenger-RNA. Molecular and Cellular Endocrinology 72(3) 187-200

Honn, K., Singley J, \& Chavin W 1975 Fetal Bovine Serum: A Multivariate Standard. Experimental Biology and Medicine 149: 344-347.

Hovey RC, Harris J, Hadsell DL, Lee AV, Ormandy CJ \& Vonderhaar BK 2003 Local insulin-like growth factor-II mediates prolactin-induced mammary gland development. Molecular Endocrinology 17(3) 460-471 
Hovey RC, Trott JF \& Vonderhaar BK 2002 Establishing a Framework for the Functional Mammary Gland: From Endocrinology to Morphology. Journal of Mammary Gland Biology and Neoplasia 7(1) 17-38

Hutton JB 1957 The effect of growth hormone on the yield and composition of cows milk. Journal of Endocrinology 16(2) 115-125

Huynh HT, Robitaille G \& Turner JD 1991 Establishment of bovine mammary epithelial-cells (MAC-T) - an in vitro model for bovine lactation. Experimental Cell Research 197(2) 191-199

Ip MM \& Darcy KM 1996 Three-dimensional mammary primary culture model systems. Journal of Mammary Gland Biology and Neoplasia 1(1) 91-110

Johnson T 2010 Growth hormone alters components related to differentiation, metabolism and milk synthesis and secretion in MAC-T cells. Vol. MS. California Polytechnic State University

Johnson TL, Fujimoto BAS, Jimenez-Flores R \& Peterson DG 2010 Growth hormone alters lipid composition and increases the abundance of casein and lactalbumin mRNA in the MAC-T cell line. Journal of Dairy Research 77(2) 199-204

Kawano A, Tateyama S, Yamaguchi R, Nosaka D \& Kondo F 1988 Morphology of goat milk-derived mammary epithelial cells cultured in collagen gel. Nippon Juigaku Zasshi 50(6) 1252-1258

Keenan TW 2001 Assembly and secretion of the lipid globules of milk. Bioactive Components of Human Milk 501 125-136

Keys J, Cifrian E, Guidry A \& Farrell H 1997 Bovine mammary explant versus primary cell cultures: Effect of bovine somatotropin and insulinlike growth factor-I on DNA content and protein synthesis. In Vitro Cellular \&amp; Developmental Biology - Animal 33(3) 206-211

Keys JE, Fekry AE, Wood DL \& Capuco AV 1992 The ability of bovine mammary tissue to synthesize lipids for 96-h when co-cultured with liver and adipose-tissue. Biochemistry and Cell Biology-Biochimie Et Biologie Cellulaire 70(5) 343-346

Kleinberg D \& Ruan WF 2008 IGF-I, GH, and Sex Steroid Effects in Normal Mammary Gland Development. Journal of Mammary Gland Biology and Neoplasia 13(4) 353-360

Kleinberg DL 1997 Early mammary development: growth hormone and IGF-1. J Mammary Gland Biol Neoplasia 2(1) 49-57

Knight CH 2000 Mammary gland development and function. The health of dairy cattle. 203-212

Knight CH 2001 Overview of prolactin's role in farm animal lactation. Livestock Production Science 70(1-2) 87-93

Kopchick JJ \& Andry JM 2000 Growth hormone (GH), GH receptor, and signal transduction. Molecular Genetics and Metabolism 71(1-2) 293-314 
Kresge N \& Simoni RD 2006 Lactose Synthesis in the Mammary Gland: Lactose Synthase and the Work of Robert L. Hill. Journal of Biological Chemistry 281(6) e6

Kulik G, Klippel A \& Weber MJ 1997 Antiapoptotic signalling by the insulin-like growth factor I receptor, phosphatidylinositol 3-kinase, and Akt. Molecular and Cellular Biology 17(3) 1595-1606

Kumar S, Clarke AR, Hooper ML, Horne DS, Law AJR, Leaver J, Springbett A, Stevenson E \& Simons JP 1994 Milk-composition and lactation of beta-caseindeficient mice. Proceedings of the National Academy of Sciences of the United States of America 91(13) 6138-6142

Larson BL 1969 Biosynthesis of Milk. Journal of Dairy Science 52(5) 737-747

Larson BL \& Smith VR 1974 Lactation: a comprehensive treatise, edited by Bruce L. Larson and Vearl R. Smith. New York: Academic Press

Le Roith D, Bondy C, Yakar S, Liu J-L \& Butler A 2001 The Somatomedin Hypothesis: 2001. Endocrine Reviews 22(1) 53-74

Lee MO \& Schaffer NK 1934 Anterior Pituitary Growth Hormone and the Composition of Growth. The Journal of Nutrition 7(3) 337-363

Leroith D, Werner H, Beitnerjohnson D \& Roberts CT 1995 Molecular and cellular aspects of the insulin-like growth-factor-i receptor. Endocrine Reviews 16(2) 143-163

Li ML, Liu XW, Robinson G, BarPeled U, Wagner KU, Young WS, Hennighausen L \& Furth PA 1997 Mammary-derived signals activate programmed cell death during the first stage of mammary gland involution. Proceedings of the National Academy of Sciences of the United States of America 94(7) 3425-3430

Liu XW, Robinson GW, Wagner KU, Garrett L, WynshawBoris A \& Hennighausen L 1997 Stat5a is mandatory for adult mammary gland development and lactogenesis. Genes \& Development 11(2) 179-186

Livak KJ \& Schmittgen TD 2001 Analysis of relative gene expression data using realtime quantitative PCR and the 2(T)(-Delta Delta C) method. Methods 25(4) 402-408

Lonnerdal B 2007 Trace element transport in the mammary gland. Annual Review of Nutrition 27 165-177

Malinowski E 2005 Mammary gland involution in cows. Medycyna Weterynaryjna 61(9) 968-971

Mallepell S, Krust Ae, Chambon P \& Brisken C 2006 Paracrine signaling through the epithelial estrogen receptor $\hat{I} \pm$ is required for proliferation and morphogenesis in the mammary gland. Proceedings of the National Academy of Sciences of the United States of America 103(7) 2196-2201

Marshman E \& Streuli CH 2002 Insulin-like growth factors and insulin-like growth factor binding proteins in mammary gland function. Breast Cancer Research 4(6) 231-239 
Marti A, Jehn B, Costello E, Keon N, Ke G, Martin F \& Jaggi R 1994 Protein kinasea and ap-1 (c-fos/jund) are induced during apoptosis of mouse mammary epithelialcells. Oncogene 9(4) 1213-1223

Mather IH \& Keenan TW 1998 Introduction - The cell biology of milk secretion: Historical notes. Journal of Mammary Gland Biology and Neoplasia 3(3) 227-232

Matitashvili E \& Bauman DE 1999 Culture of primary bovine mammary epithelial cells. In Vitro Cellular \& Developmental Biology-Animal 35(8) 431-434

McDowell GH, Gooden JM, Leenanuruksa D, Jois M \& English AW 1987 Effects of exogenous growth-hormone on milk-production and nutrient-uptake by muscle and mammary tissues of dairy-cows in midlactation. Australian Journal of Biological Sciences 40(3) 295-306

McGuire MA, Vicini JL, Bauman DE \& Veenhuizen JJ 1992 Insulin-like growthfactors and binding-proteins in ruminants and their nutritional regulation. Journal of Animal Science 70(9) 2901-2910

McManaman JL \& Neville MC 2003 Mammary physiology and milk secretion. Advanced Drug Delivery Reviews 55(5) 629-641

Menzies KK, Lefevre C, Macmillan KL \& Nicholas KR 2009 Insulin regulates milk protein synthesis at multiple levels in the bovine mammary gland. Functional \& Integrative Genomics 9(2) 197-217

Mills ES \& Topper YJ 1970 Some ultrastructural effects of insulin, hydrocortisone, and prolactin on mammary gland explants. Journal of Cell Biology 44(2) 310-\&

Murrieta CM, Hess BW, Scholljegerdes EJ, Engle TE, Hossner KL, Moss GE \& Rule DC 2006 Evaluation of milk somatic cells as a source of mRNA for study of lipogenesis in the mammary gland of lactating beef cows supplemented with dietary high-linoleate safflower seeds. Journal of Animal Science 84(9) 2399-2405

Nytes AJ, Combs DK, Shook GE, Shaver RD \& Cleale RM 1990 Response to Recombinant Bovine Somatotropin in Dairy Cows with Different Genetic Merit for Milk Production. Journal of Dairy Science 73(3) 784-791

Peel CJ \& Bauman DE 1987 Somatotropin and lactation. Journal of Dairy Science 70(2) 474-486

Peel CJ, Bauman DE, Gorewit RC \& Sniffen CJ 1981 Effect of exogenous growthhormone on lactational performance in high yielding dairy-cows. Journal of Nutrition 111(9) 1662-1671

Piwien-Pilipuk G, Huo JS \& Schwartz J 2002 Growth hormone signal transduction. Journal of Pediatric Endocrinology \& Metabolism 15(6) 771-786

Plath-Gabler A, Gabler C, Sinowatz F, Berisha B \& Schams D 2001 The expression of the IGF family and GH receptor in the bovine mammary gland. Journal of Endocrinology 168(1) 39-48 
Pocius PA \& Herbein JH 1986 Effects of in vivo administration of growth-hormone on milk-production and in vitro hepatic-metabolism in dairy-cattle. Journal of Dairy Science 69(3) 713-720

Richards J, Larson L, Yang J, Guzman R, Tomooka Y, Osborn R, Imagawa W \& Nandi S 1983 Method for culturing mammary epithelial cells in a rat tail collagen gel matrix. Methods in Cell Science 8(1) 31-36

Richert MM, Schwertfeger KL, Ryder JW \& Anderson SM 2000 An atlas of mouse mammary gland development. Journal of Mammary Gland Biology and Neoplasia 5(2) 227-241

Riley LG, Gardiner-Garden M, Thomson PC, Wynn PC, Williamson P, Raadsma HW \& Sheehy PA 2010 The influence of extracellular matrix and prolactin on global gene expression profiles of primary bovine mammary epithelial cells in vitro. Animal Genetics 41(1) 55-63

Riley LG, Williamson P, Wynn PC \& Sheeh PA 2008 Lactoferrin decreases primary bovine mammary epithelial cell viability and casein expression. Journal of Dairy Research 75(2) 135-141

Robinson GW, McKnight RA, Smith GH \& Hennighausen L 1995 Mammary epithelial cells undergo secretory differentiation in cycling virgins but require pregnancy for the establishment of terminal differentiation. Development 121(7) 2079-2090

Rohlfs EM, Louie DS \& Zeisel SH 1993 Lipid-synthesis and secretion by primary cultures of rat mammary epithelial-cells. Journal of Cellular Physiology 157(3) 469480

Rosen JM, Wyszomierski SL \& Hadsell D 1999 Regulation of milk protein gene expression. Annual Review of Nutrition 19 407-436

Rowzee AM, Ludwig DL \& Wood TL 2009 Insulin-Like Growth Factor Type 1 Receptor and Insulin Receptor Isoform Expression and Signaling in Mammary Epithelial Cells. Endocrinology 150(8) 3611-3619

Ruan WF \& Kleinberg DL 1999 Insulin-like growth factor I is essential for terminal end bud formation and ductal morphogenesis during mammary development. Endocrinology 140(11) 5075-5081

Sakamoto K, Komatsu T, Kobayashi T, Rose MT, Aso H, Hagino A \& Obara Y 2005 Growth hormone acts on the synthesis and secretion of alpha-casein in bovine mammary epithelial cells. Journal of Dairy Research 72(3) 264-270

Sakamoto K, Yano T, Kobayashi T, Hagino A, Aso H \& Obara Y 2007 Growth hormone suppresses the expression of IGFBP-5, and promotes the IGF-I-induced phosphorylation of Akt in bovine mammary epithelial cells. Domestic Animal Endocrinology 32(4) 260-272

Schmidt GH 1971 Biology of Lactation. Books on Demand 
Sejrsen K, Foldager J, Sorensen MT, Akers RM \& Bauman DE 1986 Effect of exogenous bovine somatotropin on pubertal mammary development in heifers. Journal of Dairy Science 69(6) 1528-1535

Sejrsen K, Hvelplund T \& Nielsen MO 2006 Ruminant physiology: digestion, metabolism and impact of nutrition on gene expression, immunology and stress. Xth International Symposium on Ruminant Physiology, Copenhagen, Denmark, September 2004. Ruminant physiology: digestion, metabolism and impact of nutrition on gene expression, immunology and stress. Xth International Symposium on Ruminant Physiology, Copenhagen, Denmark, September 2004. 600 pp.

Shafiei F, Herington AC \& Lobie PE 2006 Mechanisms of signal transduction utilized by growth hormone. (Elsevier

Sheehy PA, Della-Vedova JJ, Nicholas KR \& Wynn PC 2004 Hormone-dependent milk protein gene expression in bovine mammary explants from biopsies at different stages of pregnancy. Journal of Dairy Research 71(2) 135-140

Sheffield LG 1988 Organization and growth of mammary epithelia in the mammarygland fat pad. Journal of Dairy Science 71(10) 2855-2874

Shennan DB \& Peaker M 2000 Transport of milk constituents by the mammary gland. Physiological Reviews 80(3) 925-951

Soule HD, Vazquez J, Long A, Albert S \& Brennan M 1973 A human cell line from a pleural effusion derived from a breast carcinoma. Journal of the National Cancer Institute 51(5) 1409-1416

Stewart CEH \& Rotwein P 1996 Growth, differentiation, and survival: Multiple physiological functions for insulin-like growth factors. Physiological Reviews 76(4) 1005-1026

Stoker M \& Perryman M 1984 Cultures of exfoliated mammary epithelial cells: Variation between donors. Breast Cancer Research and Treatment 4(1) 11-18

Suard Y, Haeuptle M, Farinon E \& Kraehenbuhl J 1983 Cell proliferation and milk protein gene expression in rabbit mammary cell cultures. The Journal of Cell Biology 96(5) 1435-1442

Svennersten-Sjaunja K \& Olsson K 2005 Endocrinology of milk production. Domestic Animal Endocrinology 29(2) 241-258

Takeishi M, Nakamura S, Tsumagari S, Shibata M, Okuda M, Ishii T, Tsunekane T \& Yosai A 1980 Studies on the development of mammary gland in bovine fetuses. Japanese Journal of Animal Reproduction 26(3) 134-137

Taketani Y \& Oka T 1981 Hormonal induction of milk protein-synthesis in primary mammary epithelial-cell culture. Journal of Cell Biology 91(2) A217-A217

Tateyama S, Kawano A, Yamaguchi R, Nosaka D \& Kondo F 1988 Culture conditions and cell morphology of goat milk-derived mammary epithelial cells in plate culture. Nippon Juigaku Zasshi 50(6) 1192-1199 
Taylor-Papadimitriou J, Shearer M \& Stoker MGP 1977 Growth requirements of human mammary epithelial cells in culture. In Book Growth requirements of human mammary epithelial cells in culture, Vol. 20, pp. 903-908 (Ed.^Eds. Editor).Series Growth requirements of human mammary epithelial cells in culture. Wiley Subscription Services, Inc., A Wiley Company

Topper YJ \& Freeman CS 1980 Multiple hormone interactions in the developmental biology of the mammary gland. Physiological Reviews 60(4) 1049-1106

Truchet S \& Ollivier-Bousquet M 2009 Mammary gland secretion: hormonal coordination of endocytosis and exocytosis. animal 3(12) 1733-1742

Tuggle CK \& Trenkle A 1996 Control of growth hormone synthesis. Domestic Animal Endocrinology 13(1) 1-33

West JW, Bondari K \& Johnson JC 1990 Effects of bovine somatotropin on milk-yield and composition, body-weight, and condition score of Holstein and Jersey cows. Journal of Dairy Science 73(4) 1062-1068

Wheeler TT, Callaghan MR, Davis SR, Prosser CG \& Wilkins RJ 1995 Milk Protein Synthesis, Gene Expression, and Hormonal Responsiveness in Primary Cultures of Mammary Cells from Lactating Sheep. Experimental Cell Research 217(2) 346-354

Wilde CJ, Peaker M \& Knight CH 1995 Intercellular signalling in the mammary gland. Plenum Press

Yamada PM \& Lee K-W 2009 Perspectives in mammalian IGFBP-3 biology: local vs. systemic action. American Journal of Physiology - Cell Physiology 296(5) C954C976

Zhao FQ, Okine EK \& Kennelly JJ 1999 Glucose transporter gene expression in bovine mammary gland. Journal of Animal Science 77(9) 2517-2522

Zhou Y, Akers RM \& Jiang H 2008 Growth hormone can induce expression of four major milk protein genes in transfected MAC-T cells. Journal of Dairy Science 91(1) $100-108$ 


\section{$\underline{\text { Appendix }}$}

\section{QUANTITATIVE PCR DATA}

Raw data from quantitative PCR is presented in the following appendix. Briefly, raw $\mathrm{C}_{\mathrm{T}}$ values were normalized to the indicated house-keeping gene (HKG). The raw HKG $C_{T}$ value was subtracted from the gene target's raw $C_{T}$ value as an absolute value, yielding the $\Delta \Delta \mathrm{C}_{\mathrm{T}}$. The $2^{-\Delta \Delta \mathrm{C}_{\mathrm{T}}}$ method was used to calculate abundance. The 2- $\Delta \Delta \mathrm{CT}$ value was averaged within the treatment group and a standard error of the mean (SEM) was calculated.

\section{Mammary explants from a Jersey cow (Tables 1-5): raw qPCR values corresponding to results presented in Figure 4.}

\begin{tabular}{|c|c|c|c|c|c|c|c|c|}
\hline & Sample ID & $\mathbf{C}_{T}$ & HKG ID & $\mathbf{C}_{\mathrm{T}}$ & $\Delta \Delta \mathbf{C}_{\mathrm{T}}$ & $2^{-\Delta \Delta C T}$ & Average & SEM \\
\hline \multirow{6}{*}{$\hat{\bar{\theta}}$} & ALAC 1 & 23.3877 & TBP 1 & 30.7681 & 7.38040 & 0.006002 & \multirow{6}{*}{0.001955} & \multirow{6}{*}{0.000936} \\
\hline & ALAC 2 & 19.7817 & TBP 2 & 31.6413 & 11.85960 & 0.000269 & & \\
\hline & ALAC 3 & 20.0330 & TBP 3 & 30.0357 & 10.00270 & 0.000975 & & \\
\hline & ALAC 6 & 18.9668 & ТВР 6 & 30.3789 & 11.41210 & 0.000367 & & \\
\hline & ALAC 7 & 22.0721 & TBP 7 & 30.2745 & 8.20240 & 0.003395 & & \\
\hline & ALAC 8 & 20.3920 & TBP 8 & 30.8261 & 10.43410 & 0.000723 & & \\
\hline \multirow{5}{*}{ 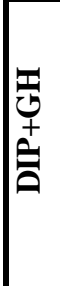 } & ALAC 10 & 22.2297 & TBP 10 & 31.0763 & 8.84660 & 0.002172 & \multirow{5}{*}{0.067483} & \multirow{5}{*}{0.027305} \\
\hline & ALAC 13 & 26.8911 & TBP 13 & 29.9393 & 3.04820 & 0.120893 & & \\
\hline & ALAC 15 & 27.3917 & TBP 15 & 31.2600 & 3.86830 & 0.068474 & & \\
\hline & ALAC 16 & 23.4633 & TBP 16 & 30.0017 & 6.53840 & 0.010758 & & \\
\hline & ALAC 18 & 26.9977 & TBP 18 & 29.8854 & 2.88770 & 0.135119 & & \\
\hline
\end{tabular}

Appendix Table 1: Q-PCR raw $\mathrm{C}_{\mathrm{T}}$ values and calculations for $\alpha$-lactalbumin mRNA abundance in mammary explants from a Jersey cow cultured for $12 \mathrm{~h}$. 


\begin{tabular}{|c|c|c|c|c|c|c|c|c|}
\hline & Sample ID & $\mathbf{C}_{\mathbf{T}}$ & HKG ID & $\mathbf{C}_{\mathbf{T}}$ & $\Delta \Delta \mathbf{C}_{\mathrm{T}}$ & $2^{-\Delta \Delta C T}$ & Average & SEM \\
\hline \multirow{3}{*}{$\hat{\bar{\alpha}}$} & CAS 1 & 18.4718 & TBP 1 & 30.7681 & 12.29630 & 0.000199 & \multirow{3}{*}{0.001879} & \multirow{3}{*}{0.001761} \\
\hline & CAS 2 & 16.9761 & TBP 2 & 31.6413 & 14.66520 & 0.000038 & & \\
\hline & CAS 5 & 22.8326 & TBP 5 & 30.3654 & 7.53280 & 0.005400 & & \\
\hline \multirow{5}{*}{ 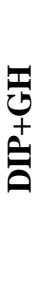 } & CAS 11 & 18.6314 & TBP 11 & 29.9068 & 11.27540 & 0.000403 & \multirow{5}{*}{0.000938} & \multirow{5}{*}{0.000575} \\
\hline & CAS 12 & 16.4670 & TBP 12 & 30.3710 & 13.90400 & 0.000065 & & \\
\hline & CAS 13 & 20.0431 & TBP 13 & 29.9393 & 9.89620 & 0.001049 & & \\
\hline & CAS 14 & 15.8211 & TBP 14 & 30.0381 & 14.21700 & 0.000053 & & \\
\hline & CAS 15 & 22.9361 & TBP 15 & 31.2600 & 8.32390 & 0.003121 & & \\
\hline
\end{tabular}

Appendix Table 2: Q-PCR raw $\mathrm{C}_{\mathrm{T}}$ values and calculations for $\alpha_{\mathrm{s} 1}$-casein mRNA abundance in mammary explants from a Jersey cow cultured for $12 \mathrm{~h}$.

\begin{tabular}{|c|c|c|c|c|c|c|c|c|}
\hline $\mathbf{T X}$ & Sample ID & $\mathbf{C}_{\mathbf{T}}$ & HKG ID & $\mathbf{C}_{\mathbf{T}}$ & $\Delta \Delta \mathbf{C}_{\mathrm{T}}$ & $2^{-\Delta \Delta C T}$ & Average & SEM \\
\hline \multirow{8}{*}{$\hat{\bar{\theta}}$} & GHR 1 & 26.6222 & TBP 1 & 30.7681 & 4.14590 & 0.056488 & \multirow{8}{*}{0.134622} & \multirow{8}{*}{0.068005} \\
\hline & GHR 2 & 26.8406 & TBP 2 & 31.6413 & 4.80070 & 0.035879 & & \\
\hline & GHR 3 & 27.613 & TBP 3 & 30.0357 & 2.42270 & 0.186507 & & \\
\hline & GHR 4 & 25.96 & TBP 4 & 30.7241 & 4.76410 & 0.036801 & & \\
\hline & GHR 5 & 29.6131 & TBP 5 & 30.3654 & 0.75230 & 0.593656 & & \\
\hline & GHR 6 & 26.3811 & TBP 6 & 30.3789 & 3.99780 & 0.062595 & & \\
\hline & GHR 7 & 26.6273 & TBP 7 & 30.2745 & 3.64720 & 0.079815 & & \\
\hline & GHR 8 & 25.5178 & TBP 8 & 30.8261 & 5.30830 & 0.025237 & & \\
\hline \multirow{9}{*}{$\begin{array}{l}\frac{\pi}{0} \\
0 \\
\text { 章 }\end{array}$} & GHR 10 & 28.9397 & TBP 10 & 31.0763 & 2.13660 & 0.227415 & \multirow{9}{*}{0.143545} & \multirow{9}{*}{0.046488} \\
\hline & GHR 11 & 26.0177 & TBP 11 & 29.9068 & 3.88910 & 0.067494 & & \\
\hline & GHR 12 & 25.128 & TBP 12 & 30.371 & 5.24300 & 0.026406 & & \\
\hline & GHR 13 & 26.3044 & TBP 13 & 29.9393 & 3.63490 & 0.080498 & & \\
\hline & GHR 14 & 25.9939 & TBP 14 & 30.0381 & 4.04420 & 0.060614 & & \\
\hline & GHR 15 & 30.1589 & TBP 15 & 31.26 & 1.10110 & 0.466161 & & \\
\hline & GHR 16 & 26.9681 & TBP 16 & 30.0017 & 3.03360 & 0.122122 & & \\
\hline & GHR 17 & 28.3196 & TBP 17 & 31.1174 & 2.79780 & 0.143806 & & \\
\hline & GHR 18 & 26.5253 & TBP 18 & 29.8854 & 3.36010 & 0.097389 & & \\
\hline
\end{tabular}

Appendix Table 3: Q-PCR raw $\mathrm{C}_{\mathrm{T}}$ values and calculations for $\mathrm{GH}$ receptor mRNA abundance in mammary explants from a Jersey cow cultured for $12 \mathrm{~h}$. 


\begin{tabular}{|c|c|c|c|c|c|c|c|c|}
\hline TX & Sample ID & $\mathbf{C}_{\mathrm{T}}$ & HKG ID & $\mathbf{C}_{\mathrm{T}}$ & $\Delta \Delta \mathbf{C}_{\mathrm{T}}$ & $2^{-\Delta \Delta C T}$ & Average & SEM \\
\hline \multirow{5}{*}{$\hat{\bar{\theta}}$} & IGF-1 1 & 28.1265 & TBP 1 & 30.7681 & 2.64160 & 0.160250 & \multirow{5}{*}{0.143852} & \multirow{5}{*}{0.016590} \\
\hline & IGF-1 2 & 28.7227 & TBP 2 & 31.6413 & 2.91860 & 0.132256 & & \\
\hline & IGF-1 6 & 28.0533 & TBP 6 & 30.3789 & 2.32560 & 0.199492 & & \\
\hline & IGF-1 7 & 27.2523 & TBP 7 & 30.2745 & 3.02220 & 0.123091 & & \\
\hline & IGF-1 8 & 27.5631 & TBP 8 & 30.8261 & 3.26300 & 0.104169 & & \\
\hline \multirow{7}{*}{ 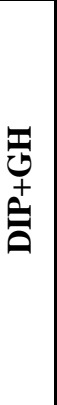 } & IGF-1 11 & 26.1650 & TBP 11 & 29.9068 & 3.74180 & 0.074749 & \multirow{7}{*}{0.155514} & \multirow{7}{*}{0.033081} \\
\hline & IGF-1 12 & 26.5807 & TBP 12 & 30.3710 & 3.79030 & 0.072278 & & \\
\hline & IGF-1 13 & 26.8985 & TBP 13 & 29.9393 & 3.04080 & 0.121514 & & \\
\hline & IGF-1 15 & 29.4842 & TBP 15 & 31.2600 & 1.77580 & 0.292032 & & \\
\hline & IGF-1 16 & 27.7479 & TBP 16 & 30.0017 & 2.25380 & 0.209671 & & \\
\hline & IGF-1 17 & 28.9910 & TBP 17 & 31.1174 & 2.12640 & 0.229029 & & \\
\hline & IGF-1 18 & 26.4006 & TBP 18 & 29.8854 & 3.48480 & 0.089325 & & \\
\hline
\end{tabular}

Appendix Table 4: Q-PCR raw $\mathrm{C}_{\mathrm{T}}$ values and calculations for IGF-I mRNA abundance in mammary explants from a Jersey cow cultured for $12 \mathrm{~h}$.

\begin{tabular}{|c|c|c|c|c|c|c|c|c|}
\hline TX & Sample ID & $\mathbf{C}_{\mathbf{T}}$ & HKG ID & $\mathbf{C}_{\mathrm{T}}$ & $\Delta \Delta \mathbf{C}_{\mathbf{T}}$ & $2^{-\Delta \Delta C T}$ & Average & SEM \\
\hline \multirow{5}{*}{$\hat{\bar{\theta}}$} & IGFBP3 1 & 24.028 & TBP 1 & 30.7681 & 6.74010 & 0.009355 & \multirow{5}{*}{0.009059} & \multirow{5}{*}{0.001630} \\
\hline & IGFBP3 2 & 24.1119 & TBP 2 & 31.6413 & 7.52940 & 0.005413 & & \\
\hline & IGFBP3 3 & 23.7328 & TBP 3 & 30.0357 & 6.30290 & 0.012666 & & \\
\hline & IGFBP3 4 & 23.158 & TBP 4 & 30.7241 & 7.56610 & 0.005277 & & \\
\hline & IGFBP3 6 & 24.0665 & TBP 6 & 30.3789 & 6.31240 & 0.012583 & & \\
\hline \multirow{6}{*}{\begin{tabular}{|l}
$\bar{E}$ \\
+ \\
+ \\
$\hat{\bar{\theta}}$ \\
$\hat{\theta}$
\end{tabular}} & IGFBP3 12 & 23.0041 & TBP 12 & 30.371 & 7.36690 & 0.006058 & \multirow{6}{*}{0.017787} & \multirow{6}{*}{0.004616} \\
\hline & IGFBP3 13 & 24.0115 & TBP 13 & 29.9393 & 5.92780 & 0.016427 & & \\
\hline & IGFBP3 14 & 23.288 & TBP 14 & 30.0381 & 6.75010 & 0.009290 & & \\
\hline & IGFBP3 16 & 25.2369 & TBP 16 & 30.0017 & 4.76480 & 0.036783 & & \\
\hline & IGFBP3 17 & 25.7785 & TBP 17 & 31.1174 & 5.33890 & 0.024708 & & \\
\hline & IGFBP3 18 & 23.67 & TBP 18 & 29.8854 & 6.21540 & 0.013458 & & \\
\hline
\end{tabular}

Appendix Table 5: Q-PCR raw $\mathrm{C}_{\mathrm{T}}$ values and calculations for IGFBP3 mRNA abundance in mammary explants from a Jersey cow cultured for $12 \mathrm{~h}$. 
Primary MEC from a Jersey cow (Tables 6-10): raw qPCR values corresponding to results presented in Figure 5.

\begin{tabular}{|c|c|c|c|c|c|c|c|c|}
\hline $\mathbf{T X}$ & Sample ID & $\mathbf{C}_{\mathbf{T}}$ & HKG ID & $\mathbf{C}_{\mathbf{T}}$ & $\Delta \Delta \mathbf{C}_{\mathrm{T}}$ & $2^{-\Delta \Delta C T}$ & Average & SEM \\
\hline \multirow{4}{*}{ 흠 } & ALAC 1 & 33.8750 & $18 \mathrm{~S} 1$ & 12.61380 & 21.26120 & 3.978699E-07 & \multirow{4}{*}{$1.091965 \mathrm{E}-06$} & \multirow{4}{*}{ 4.989461E-07 } \\
\hline & ALAC 2 & 32.4164 & $18 \mathrm{~S} 2$ & 13.34990 & 19.06650 & $1.821426 \mathrm{E}-06$ & & \\
\hline & ALAC 3 & 33.2099 & $18 \mathrm{~S} 3$ & 14.32620 & 18.88370 & 2.067473E-06 & & \\
\hline & ALAC 4 & 36.0860 & $18 \mathrm{~S} 4$ & 12.53010 & 23.55590 & 8.109004E-08 & & \\
\hline \multirow{4}{*}{ 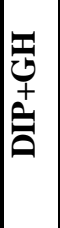 } & ALAC 5 & 33.6129 & $18 \mathrm{~S} 5$ & 12.05600 & 21.55690 & 3.241354E-07 & \multirow{4}{*}{$8.227119 \mathrm{E}-07$} & \multirow{4}{*}{$2.606856 \mathrm{E}-07$} \\
\hline & ALAC 6 & 33.2850 & $18 \mathrm{~S} 6$ & 12.95840 & 20.32660 & 7.604728E-07 & & \\
\hline & ALAC 7 & 33.1465 & $18 \mathrm{~S} 7$ & 13.85050 & 19.29600 & 1.553550E-06 & & \\
\hline & ALAC 8 & 33.2366 & $18 \mathrm{~S} 8$ & 12.68950 & 20.54710 & 6.526894E-07 & & \\
\hline
\end{tabular}

Appendix Table 6: Q-PCR raw $\mathrm{C}_{\mathrm{T}}$ values and calculations for $\alpha$-lactalbumin mRNA abundance in primary MEC from a Jersey cow cultured for $7 \mathrm{~d}$.

\begin{tabular}{|c|c|c|c|c|c|c|c|c|}
\hline TX & Sample ID & $\mathbf{C}_{\mathbf{T}}$ & HKG ID & $\mathbf{C}_{\mathbf{T}}$ & $\Delta \Delta \mathbf{C}_{\mathrm{T}}$ & $2^{-\Delta \Delta C T}$ & Average & SEM \\
\hline \multirow{4}{*}{$\hat{\bar{\theta}}$} & CAS 1 & 30.8435 & $18 \mathrm{~S} 1$ & 12.6138 & 18.2297 & $3.253220 \mathrm{E}-06$ & \multirow{4}{*}{$7.224671 \mathrm{E}-06$} & \multirow{4}{*}{ 2.912437E-06 } \\
\hline & CAS 2 & 30.9295 & $18 \mathrm{~S} 2$ & 13.3499 & 17.5796 & $5.105204 \mathrm{E}-06$ & & \\
\hline & CAS 3 & 30.2685 & $18 \mathrm{~S} 3$ & 14.3262 & 15.9423 & $1.588143 \mathrm{E}-05$ & & \\
\hline & CAS 4 & 30.2417 & $18 \mathrm{~S} 4$ & 12.5301 & 17.7116 & 4.658833E-06 & & \\
\hline \multirow{4}{*}{ 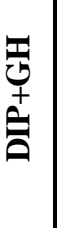 } & CAS 5 & 29.2374 & $18 \mathrm{~S} 5$ & 12.056 & 17.1814 & 6.727957E-06 & \multirow{4}{*}{$1.400971 \mathrm{E}-05$} & \multirow{4}{*}{ 4.422066E-06 } \\
\hline & CAS 6 & 29.6532 & $18 \mathrm{~S} 6$ & 12.9584 & 16.6948 & $9.426803 \mathrm{E}-06$ & & \\
\hline & CAS 7 & 29.0455 & $18 \mathrm{~S} 7$ & 13.8505 & 15.195 & 2.665933E-05 & & \\
\hline & CAS 8 & 28.8959 & $18 \mathrm{~S} 8$ & 12.6895 & 16.2064 & $1.322475 \mathrm{E}-05$ & & \\
\hline
\end{tabular}

Appendix Table 7: Q-PCR raw $\mathrm{C}_{\mathrm{T}}$ values and calculations for $\alpha_{\mathrm{S} 1}$-casein $\mathrm{mRNA}$ abundance in primary MEC from a Jersey cow cultured for $7 \mathrm{~d}$.

\begin{tabular}{|c|c|c|c|c|c|c|c|c|}
\hline TX & Sample ID & $\mathbf{C}_{\mathbf{T}}$ & HKG ID & $\mathbf{C}_{\mathbf{T}}$ & $\Delta \Delta \mathbf{C}_{\mathrm{T}}$ & $2^{-\Delta \Delta C T}$ & Average & SEM \\
\hline \multirow{4}{*}{$\hat{\bar{a}}$} & GHR 1 & 26.4361 & $18 \mathrm{~S} 1$ & 12.6138 & 13.8223 & $6.903560 \mathrm{E}-05$ & \multirow{4}{*}{$8.035560 \mathrm{E}-05$} & \multirow{4}{*}{ 5.855804E-06 } \\
\hline & GHR 2 & 27.0933 & $18 \mathrm{~S} 2$ & 13.3499 & 13.7434 & 7.291626E-05 & & \\
\hline & GHR 3 & 27.8546 & $18 \mathrm{~S} 3$ & 14.3262 & 13.5284 & 8.463418E-05 & & \\
\hline & GHR 4 & 25.8943 & $18 \mathrm{~S} 4$ & 12.5301 & 13.3642 & 9.483637E-05 & & \\
\hline \multirow{3}{*}{$\begin{array}{l}\overline{\mathbf{T}} \\
0 \\
\overline{0} \\
\hat{0}\end{array}$} & GHR 5 & 25.2033 & $18 \mathrm{~S} 5$ & 12.056 & 13.1473 & 1.102220E-04 & \multirow{3}{*}{$1.852639 \mathrm{E}-04$} & \multirow{3}{*}{ 4.524816E-05 } \\
\hline & GHR 6 & 25.4063 & $18 \mathrm{~S} 6$ & 12.9584 & 12.4479 & $1.789817 \mathrm{E}-04$ & & \\
\hline & GHR 8 & 24.5626 & $18 \mathrm{~S} 8$ & 12.6895 & 11.8731 & 2.665881E-04 & & \\
\hline
\end{tabular}

Appendix Table 8: Q-PCR raw $\mathrm{C}_{\mathrm{T}}$ values and calculations for $\mathrm{GH}$ receptor mRNA abundance in primary MEC from a Jersey cow cultured for $7 \mathrm{~d}$. 


\begin{tabular}{|c|c|c|c|c|c|c|c|c|}
\hline TX & Sample ID & $\mathbf{C}_{\mathbf{T}}$ & HKG ID & $\mathbf{C}_{\mathbf{T}}$ & $\Delta \Delta \mathbf{C}_{\mathbf{T}}$ & $2^{-\Delta \Delta C T}$ & Average & SEM \\
\hline \multirow{4}{*}{$\hat{\bar{\theta}}$} & IGF-1 1 & 31.885 & $18 \mathrm{~S} 1$ & 12.6138 & 19.2712 & $1.580486 \mathrm{E}-06$ & \multirow{4}{*}{ 7.413002E-06 } & \multirow{4}{*}{ 3.202423E-06 } \\
\hline & IGF-1 2 & 29.8172 & $18 \mathrm{~S} 2$ & 13.3499 & 16.4673 & 1.103694E-05 & & \\
\hline & IGF-1 3 & 30.392 & $18 \mathrm{~S} 3$ & 14.3262 & 16.0658 & $1.457848 \mathrm{E}-05$ & & \\
\hline & IGF-1 4 & 31.1653 & $18 \mathrm{~S} 4$ & 12.5301 & 18.6352 & $2.456099 \mathrm{E}-06$ & & \\
\hline \multirow{4}{*}{ 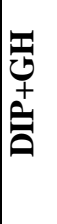 } & IGF-1 5 & 30.7174 & $18 \mathrm{~S} 5$ & 12.056 & 18.6614 & $2.411897 \mathrm{E}-06$ & \multirow{4}{*}{ 6.658784E-06 } & \multirow{4}{*}{ 2.202387E-0e } \\
\hline & IGF-1 6 & 31.1657 & $18 \mathrm{~S} 6$ & 12.9584 & 18.2073 & $3.304126 \mathrm{E}-06$ & & \\
\hline & IGF-1 7 & 30.4107 & $18 \mathrm{~S} 7$ & 13.8505 & 16.5602 & $1.034863 \mathrm{E}-05$ & & \\
\hline & IGF-1 8 & 29.2191 & $18 \mathrm{~S} 8$ & 12.6895 & 16.5296 & $1.057048 \mathrm{E}-05$ & & \\
\hline
\end{tabular}

Appendix Table 9: Q-PCR raw $\mathrm{C}_{\mathrm{T}}$ values and calculations for IGF-I mRNA abundance in primary MEC from a Jersey cow cultured for $7 \mathrm{~d}$.

\begin{tabular}{|c|c|c|c|c|c|c|c|c|}
\hline TX & Sample ID & $\mathbf{C}_{\mathrm{T}}$ & HKG ID & $\mathrm{C}_{\mathrm{T}}$ & $\Delta \Delta \mathbf{C}_{\mathrm{T}}$ & $2^{-\Delta \Delta C T}$ & Average & SEM \\
\hline \multirow{4}{*}{$\hat{\bar{\theta}}$} & IGFBP3 1 & 19.6852 & $18 \mathrm{~S} 1$ & 12.6138 & 7.0714 & 0.007435 & \multirow{4}{*}{0.003667} & \multirow{4}{*}{0.001535} \\
\hline & IGFBP3 2 & 24.8863 & $18 \mathrm{~S} 2$ & 13.3499 & 11.5364 & 0.000337 & & \\
\hline & IGFBP3 3 & 22.0761 & $18 \mathrm{~S} 3$ & 14.3262 & 7.7499 & 0.004646 & & \\
\hline & IGFBP3 4 & 21.3261 & 18S 4 & 12.5301 & 8.796 & 0.002250 & & \\
\hline \multirow{4}{*}{ 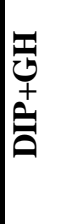 } & IGFBP3 5 & 22.4727 & $18 \mathrm{~S} 5$ & 12.056 & 10.4167 & 0.000732 & \multirow{4}{*}{0.001288} & \multirow{4}{*}{0.000681} \\
\hline & IGFBP3 6 & 21.1982 & $18 \mathrm{~S} 6$ & 12.9584 & 8.2398 & 0.003308 & & \\
\hline & IGFBP3 7 & 24.1743 & $18 \mathrm{~S} 7$ & 13.8505 & 10.3238 & 0.000780 & & \\
\hline & IGFBP3 8 & 24.2517 & $18 \mathrm{~S} 8$ & 12.6895 & 11.5622 & 0.000331 & & \\
\hline
\end{tabular}

Appendix Table 10: Q-PCR raw $\mathrm{C}_{\mathrm{T}}$ values and calculations for IGFBP-3 mRNA abundance in primary MEC from a Jersey cow cultured for $7 \mathrm{~d}$. 
Primary MEC from a Holstein cow (Tables 11-15): raw qPCR values corresponding to results presented in Figure 6.

\begin{tabular}{|c|c|c|c|c|c|c|c|c|}
\hline $\mathbf{T X}$ & Sample ID & $\mathbf{C}_{\mathbf{T}}$ & HKG ID & $\mathbf{C}_{\mathbf{T}}$ & $\Delta \Delta \mathbf{C}_{\mathbf{T}}$ & $2^{-\Delta \Delta C T}$ & Average & SEM \\
\hline \multirow{4}{*}{$\hat{\overline{\mathbf{D}}}$} & ALAC 1 & 35.0438 & $18 \mathrm{~S} 1$ & 14.0686 & 20.9752 & 4.851049E-07 & \multirow{4}{*}{ 4.346979E-07 } & \multirow{4}{*}{ 4.434087E-08 } \\
\hline & ALAC 2 & 35.2205 & $18 \mathrm{~S} 2$ & 13.7097 & 21.5108 & 3.346601E-07 & & \\
\hline & ALAC 3 & 34.9493 & $18 \mathrm{~S} 3$ & 14.1006 & 20.8487 & 5.295609E-07 & & \\
\hline & ALAC 4 & 35.0254 & $18 \mathrm{~S} 4$ & 13.7334 & 21.292 & 3.894658E-07 & & \\
\hline \multirow{3}{*}{$\begin{array}{l}\bar{T} \\
0 \\
+ \\
\hat{0} \\
0\end{array}$} & ALAC 5 & 35.4095 & $18 \mathrm{~S} 5$ & 13.8183 & 21.5912 & $3.165200 \mathrm{E}-07$ & \multirow{3}{*}{ 4.349154E-07 } & \multirow{3}{*}{$6.046438 \mathrm{E}-08$} \\
\hline & ALAC 6 & 34.4291 & $18 \mathrm{~S} 6$ & 13.5414 & 20.8877 & 5.154372E-07 & & \\
\hline & ALAC 7 & 34.3402 & $18 \mathrm{~S} 7$ & 13.3279 & 21.0123 & 4.727891E-07 & & \\
\hline
\end{tabular}

Appendix Table 11: $\mathrm{Q}-\mathrm{PCR}$ raw $\mathrm{C}_{\mathrm{T}}$ values and calculations for $\alpha$-lactalbumin $\mathrm{mRNA}$ abundance in primary MEC from a Holstein cow cultured for $7 \mathrm{~d}$.

\begin{tabular}{|c|c|c|c|c|c|c|c|c|}
\hline TX & Sample ID & $\mathbf{C}_{\mathbf{T}}$ & HKG ID & $\mathbf{C}_{\mathbf{T}}$ & $\Delta \Delta \mathbf{C}_{\mathbf{T}}$ & $2^{-\Delta \Delta C T}$ & Average & SEM \\
\hline \multirow{4}{*}{$\hat{\bar{a}}$} & CAS 1 & 37.6757 & $18 \mathrm{~S} 1$ & 14.0686 & 23.6071 & 7.826269E-08 & \multirow{4}{*}{ 3.191571E-08 } & \multirow{4}{*}{$1.660944 \mathrm{E}-08$} \\
\hline & CAS 2 & 42.9531 & $18 \mathrm{~S} 2$ & 13.7097 & 29.2434 & $1.573473 \mathrm{E}-09$ & & \\
\hline & CAS 3 & 39.9647 & $18 \mathrm{~S} 3$ & 14.1006 & 25.8641 & 1.637307E-08 & & \\
\hline & CAS 4 & 38.6556 & $18 \mathrm{~S} 4$ & 13.7334 & 24.9222 & $3.145359 \mathrm{E}-08$ & & \\
\hline \multirow{4}{*}{ 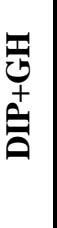 } & CAS 5 & 41.7294 & $18 \mathrm{~S} 5$ & 13.8183 & 27.9111 & 3.962066E-09 & \multirow{4}{*}{$9.471850 \mathrm{E}-08$} & \multirow{4}{*}{$8.463085 \mathrm{E}-08$} \\
\hline & CAS 6 & 38.8596 & $18 \mathrm{~S} 6$ & 13.5414 & 25.3182 & 2.390355E-08 & & \\
\hline & CAS 7 & 41.7331 & $18 \mathrm{~S} 7$ & 13.3279 & 28.4052 & $2.813084 \mathrm{E}-09$ & & \\
\hline & CAS 8 & 36.3013 & $18 \mathrm{~S} 8$ & 14.8477 & 21.4536 & 3.481953E-07 & & \\
\hline
\end{tabular}

Appendix Table 12: Q-PCR raw $\mathrm{C}_{\mathrm{T}}$ values and calculations for $\alpha_{\mathrm{S} 1}$-casein mRNA abundance in primary MEC from a Holstein cow cultured for $7 \mathrm{~d}$.

\begin{tabular}{|c|c|c|c|c|c|c|c|c|}
\hline TX & Sample ID & $\mathbf{C}_{\mathbf{T}}$ & HKG ID & $\mathbf{C}_{\mathbf{T}}$ & $\Delta \Delta \mathbf{C}_{\mathbf{T}}$ & $2^{-\Delta \Delta C T}$ & Average & SEM \\
\hline \multirow{4}{*}{$\hat{\bar{\rho}}$} & GHR 1 & 25.2728 & $18 \mathrm{~S} 1$ & 14.0686 & 11.2042 & 0.000423838 & \multirow{4}{*}{0.00030858} & \multirow{4}{*}{0.00004790} \\
\hline & GHR 2 & 25.6855 & $18 \mathrm{~S} 2$ & 13.7097 & 11.9758 & 0.00024827 & & \\
\hline & GHR 3 & 25.5869 & $18 \mathrm{~S} 3$ & 14.1006 & 11.4863 & 0.000348561 & & \\
\hline & GHR 4 & 25.9259 & $18 \mathrm{~S} 4$ & 13.7334 & 12.1925 & 0.000213645 & & \\
\hline \multirow{4}{*}{ 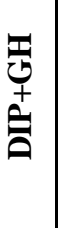 } & GHR 5 & 25.7405 & $18 \mathrm{~S} 5$ & 13.8183 & 11.9222 & 0.000257668 & \multirow{4}{*}{0.00035632} & \multirow{4}{*}{0.00011547} \\
\hline & GHR 6 & 25.5746 & $18 \mathrm{~S} 6$ & 13.5414 & 12.0332 & 0.000238586 & & \\
\hline & GHR 7 & 25.434 & $18 \mathrm{~S} 7$ & 13.3279 & 12.1061 & 0.00022683 & & \\
\hline & GHR 8 & 25.3235 & $18 \mathrm{~S} 8$ & 14.8477 & 10.4758 & 0.000702215 & & \\
\hline
\end{tabular}

Appendix Table 13: Q-PCR raw $\mathrm{C}_{\mathrm{T}}$ values and calculations for $\mathrm{GH}$ receptor mRNA abundance in primary MEC from a Holstein cow cultured for $7 \mathrm{~d}$. 


\begin{tabular}{|c|c|c|c|c|c|c|c|c|}
\hline TX & Sample ID & $\mathbf{C}_{T}$ & HKG ID & $\mathbf{C}_{T}$ & $\Delta \Delta \mathbf{C}_{\mathbf{T}}$ & $2^{-\Delta \Delta C T}$ & Average & SEM \\
\hline \multirow{4}{*}{$\hat{\bar{\theta}}$} & IGF-1 1 & 28.6594 & $18 \mathrm{~S} 1$ & 14.0686 & 14.5908 & $4.052579 \mathrm{E}-05$ & \multirow{4}{*}{ 5.733957E-05 } & \multirow{4}{*}{$8.389575 \mathrm{E}-06$} \\
\hline & IGF-1 2 & 27.4961 & $18 \mathrm{~S} 2$ & 13.7097 & 13.7864 & 7.077503E-05 & & \\
\hline & IGF-1 3 & 27.8476 & $18 \mathrm{~S} 3$ & 14.1006 & 13.747 & 7.273453E-05 & & \\
\hline & IGF-1 4 & 28.1628 & $18 \mathrm{~S} 4$ & 13.7334 & 14.4294 & $4.532291 \mathrm{E}-05$ & & \\
\hline \multirow{4}{*}{ 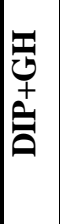 } & IGF-1 5 & 28.5876 & $18 \mathrm{~S} 5$ & 13.8183 & 14.7693 & $3.580945 \mathrm{E}-05$ & \multirow{4}{*}{$1.042875 \mathrm{E}-04$} & \multirow{4}{*}{ 6.051191E-05 } \\
\hline & IGF-1 6 & 28.145 & $18 \mathrm{~S} 6$ & 13.5414 & 14.6036 & 4.016783E-05 & & \\
\hline & IGF-1 7 & 27.4571 & $18 \mathrm{~S} 7$ & 13.3279 & 14.1292 & $5.580678 \mathrm{E}-05$ & & \\
\hline & IGF-1 8 & 26.6226 & $18 \mathrm{~S} 8$ & 14.8477 & 11.7749 & 2.853658E-04 & & \\
\hline
\end{tabular}

Appendix Table 14: Q-PCR raw $\mathrm{C}_{\mathrm{T}}$ values and calculations for IGF-I mRNA abundance in primary MEC from a Holstein cow cultured for $7 \mathrm{~d}$.

\begin{tabular}{|c|c|c|c|c|c|c|c|c|}
\hline TX & Sample ID & $\mathbf{C}_{\mathbf{T}}$ & HKG ID & $\mathbf{C}_{\mathbf{T}}$ & $\Delta \Delta \mathbf{C}_{\mathrm{T}}$ & $2^{-\Delta \Delta C T}$ & Average & SEM \\
\hline \multirow{4}{*}{$\hat{\bar{\theta}}$} & IGFBP3 1 & 18.9506 & $18 \mathrm{~S} 1$ & 14.0686 & 4.882 & 0.033913 & \multirow{4}{*}{0.014598} & \multirow{4}{*}{0.006467} \\
\hline & IGFBP3 2 & 20.942 & $18 \mathrm{~S} 2$ & 3.7097 & 7.2323 & 0.006651 & & \\
\hline & IGFBP3 3 & 21.0318 & $18 \mathrm{~S} 3$ & 14.1006 & 6.9312 & 0.008194 & & \\
\hline & IGFBP3 4 & 20.4311 & $18 \mathrm{~S} 4$ & 13.7334 & 6.6977 & 0.009634 & & \\
\hline \multirow{4}{*}{$\bar{a}$} & IGFBP3 5 & 20.4531 & $18 \mathrm{~S} 5$ & 13.8183 & 6.6348 & 0.010063 & \multirow{4}{*}{0.010478} & \multirow{4}{*}{0.001857} \\
\hline & IGFBP3 6 & 20.3526 & $18 \mathrm{~S} 6$ & 13.5414 & 6.8112 & 0.008905 & & \\
\hline & IGFBP3 7 & 20.4487 & $18 \mathrm{~S} 7$ & 13.3279 & 7.1208 & 0.007185 & & \\
\hline & IGFBP3 8 & 20.8353 & $18 \mathrm{~S} 8$ & 14.8477 & 5.9876 & 0.015760 & & \\
\hline
\end{tabular}

Appendix Table 15: Q-PCR raw $\mathrm{C}_{\mathrm{T}}$ values and calculations for IGFBP-3 mRNA abundance in primary MEC from a Holstein cow cultured for $7 \mathrm{~d}$. 
MEC from Holstein milk (Tables 16-20): raw qPCR values corresponding to results presented in Figure 7.

\begin{tabular}{|c|c|c|c|c|c|c|c|c|}
\hline TX & Sample ID & $\mathbf{C}_{\mathrm{T}}$ & HKG ID & $\mathbf{C}_{\mathrm{T}}$ & $\Delta \Delta \mathbf{C}_{\mathrm{T}}$ & $2^{-\Delta \Delta C T}$ & Average & SEM \\
\hline \multirow{4}{*}{ 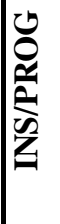 } & ALAC 2 & 39.0751 & TBP 2 & 22.46722422 & 16.60787578 & $1.00122 \mathrm{E}-05$ & \multirow{4}{*}{$1.58326 \mathrm{E}-05$} & \multirow{4}{*}{$3.22302 \mathrm{E}-06$} \\
\hline & ALAC 3 & 37.2106 & TBP 3 & 21.57255561 & 15.63804439 & $1.96101 \mathrm{E}-05$ & & \\
\hline & ALAC 4 & 38.0784 & TBP 4 & 21.57362486 & 16.50477514 & $1.07539 \mathrm{E}-05$ & & \\
\hline & ALAC 5 & 37.166 & TBP 5 & 21.75510852 & 15.41089148 & 2.29541E-05 & & \\
\hline \multirow{5}{*}{$\overline{\bar{\theta}}$} & ALAC 6 & 36.6503 & TBP 6 & 22.13608466 & 14.51421534 & 4.27352E-05 & \multirow{5}{*}{$2.07183 \mathrm{E}-05$} & \multirow{5}{*}{ 7.90292E-06 } \\
\hline & ALAC 7 & 37.2433 & TBP 7 & 22.45249931 & 14.79080069 & $3.52797 \mathrm{E}-05$ & & \\
\hline & ALAC 8 & 37.8777 & TBP 8 & 21.6431689 & 16.2345311 & $1.29694 \mathrm{E}-05$ & & \\
\hline & ALAC 9 & 44.9402 & TBP 9 & 21.81917515 & 23.12102485 & $1.09617 \mathrm{E}-07$ & & \\
\hline & ALAC 10 & 37.8668 & TBP 10 & 21.57881884 & 16.28798116 & $1.24977 \mathrm{E}-05$ & & \\
\hline \multirow{5}{*}{ 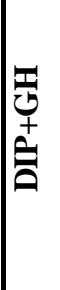 } & ALAC 11 & 35.3894 & TBP 11 & 22.06155041 & 13.32784959 & 9.72562E-05 & \multirow{5}{*}{$5.65669 \mathrm{E}-05$} & \multirow{5}{*}{$1.56171 \mathrm{E}-05$} \\
\hline & ALAC 12 & 36.2938 & TBP 12 & 22.17592414 & 14.11787586 & 5.62466E-05 & & \\
\hline & ALAC 13 & 36.3021 & TBP 13 & 22.45877618 & 13.84332382 & $6.80369 \mathrm{E}-05$ & & \\
\hline & ALAC 14 & 41.8127 & TBP 14 & 22.0093804 & 19.8033196 & $1.09297 \mathrm{E}-06$ & & \\
\hline & ALAC 15 & 36.1221 & TBP 15 & 22.10227343 & 14.01982657 & $6.02021 \mathrm{E}-05$ & & \\
\hline
\end{tabular}

Appendix Table 16: Q-PCR raw $\mathrm{C}_{\mathrm{T}}$ values and calculations for $\alpha$-lactalbumin mRNA abundance in MEC from Holstein milk cultured for $7 \mathrm{~d}$. 


\begin{tabular}{|c|c|c|c|c|c|c|c|c|}
\hline $\mathbf{T X}$ & Sample ID & $\mathbf{C}_{\mathbf{T}}$ & HKG ID & $\mathbf{C}_{\mathbf{T}}$ & $\Delta \Delta \mathbf{C}_{\mathrm{T}}$ & $2^{-\Delta \Delta C T}$ & Average & SEM \\
\hline \multirow{5}{*}{ 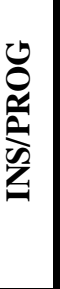 } & CAS 1 & 39.1774 & TBP 1 & 22.47289944 & 16.70450056 & $9.36363 \mathrm{E}-06$ & \multirow{5}{*}{$1.15504 \mathrm{E}-05$} & \multirow{5}{*}{ 2.14207E-06 } \\
\hline & CAS 2 & 39.5444 & TBP 2 & 22.46722422 & 17.07717578 & 7.23199E-06 & & \\
\hline & CAS 3 & 37.4151 & TBP 3 & 21.57255561 & 15.84254439 & 1.70184E-05 & & \\
\hline & CAS 4 & 38.5574 & TBP 4 & 21.57362486 & 16.98377514 & $7.71568 \mathrm{E}-06$ & & \\
\hline & CAS 5 & 37.6491 & TBP 5 & 21.75510852 & 15.89399148 & 1.64222E-05 & & \\
\hline \multirow{5}{*}{$\hat{\bar{a}}$} & CAS 6 & 34.2626 & TBP 6 & 22.13608466 & 12.12651534 & 0.000223643 & \multirow{5}{*}{0.00026227} & \multirow{5}{*}{ 2.54201E-05 } \\
\hline & CAS 7 & 34.1528 & TBP 7 & 22.45249931 & 11.70030069 & 0.00030051 & & \\
\hline & CAS 8 & 33.9849 & TBP 8 & 21.6431689 & 12.3417311 & 0.00019265 & & \\
\hline & CAS 9 & 33.3678 & TBP 9 & 21.81917515 & 11.54862485 & 0.000333824 & & \\
\hline & CAS 10 & 33.484 & TBP 10 & 21.57881884 & 11.90518116 & 0.000260725 & & \\
\hline \multirow{5}{*}{ 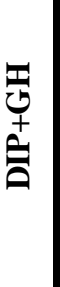 } & CAS 11 & 35.5343 & TBP 11 & 22.06155041 & 13.47274959 & $8.79626 \mathrm{E}-05$ & \multirow{5}{*}{0.000585178} & \multirow{5}{*}{0.000189884} \\
\hline & CAS 12 & 34.6928 & TBP 12 & 22.17592414 & 12.51687586 & 0.000170626 & & \\
\hline & CAS 13 & 32.4097 & TBP 13 & 22.45877618 & 9.950923817 & 0.001010354 & & \\
\hline & CAS 14 & 32.182 & TBP 14 & 22.0093804 & 10.1726196 & 0.000866436 & & \\
\hline & CAS 15 & 32.4072 & TBP 15 & 22.10227343 & 10.30492657 & 0.000790511 & & \\
\hline
\end{tabular}

Appendix Table 17: Q-PCR raw $\mathrm{C}_{\mathrm{T}}$ values and calculations for $\alpha_{\mathrm{s} 1}$-casein mRNA abundance in MEC from Holstein milk cultured for $7 \mathrm{~d}$.

\begin{tabular}{|c|c|c|c|c|c|c|c|c|}
\hline TX & Sample ID & $\mathbf{C}_{\mathbf{T}}$ & HKG ID & $\mathbf{C}_{\mathbf{T}}$ & $\Delta \Delta \mathbf{C}_{\mathrm{T}}$ & $2^{-\Delta \Delta C T}$ & Average & SEM \\
\hline \multirow{5}{*}{ 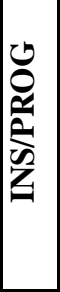 } & GHR 1 & 34.1009 & TBP 1 & 22.47289944 & 11.62800056 & 0.000315953 & \multirow{5}{*}{0.000398088} & \multirow{5}{*}{ 4.70582E-05 } \\
\hline & GHR 2 & 34.0955 & TBP 2 & 22.46722422 & 11.62827578 & 0.000315893 & & \\
\hline & GHR 3 & 33.0429 & TBP 3 & 21.57255561 & 11.47034439 & 0.000352438 & & \\
\hline & GHR 4 & 32.7063 & TBP 4 & 21.57362486 & 11.13267514 & 0.00044538 & & \\
\hline & GHR 5 & 32.5554 & TBP 5 & 21.75510852 & 10.80029148 & 0.000560775 & & \\
\hline \multirow{5}{*}{$\hat{\bar{\theta}}$} & GHR 6 & 31.8345 & TBP 6 & 22.13608466 & 9.698415344 & 0.001203611 & \multirow{5}{*}{0.001191864} & \multirow{5}{*}{0.000119915} \\
\hline & GHR 7 & 31.7484 & TBP 7 & 22.45249931 & 9.295900687 & 0.001590945 & & \\
\hline & GHR 8 & 31.413 & TBP 8 & 21.6431689 & 9.769831095 & 0.001145481 & & \\
\hline & GHR 9 & 32.0417 & ТВР 9 & 21.81917515 & 10.22252485 & 0.000836977 & & \\
\hline & GHR 10 & 31.303 & TBP 10 & 21.57881884 & 9.724181157 & 0.001182306 & & \\
\hline \multirow{5}{*}{$\begin{array}{l}\mathbf{T} \\
0 \\
+ \\
\hat{\mathbf{a}}\end{array}$} & GHR 11 & 32.0181 & TBP 11 & 22.06155041 & 9.956549592 & 0.001006422 & \multirow{5}{*}{0.001168319} & \multirow{5}{*}{0.00019359} \\
\hline & GHR 12 & 32.7346 & TBP 12 & 22.17592414 & 10.55867586 & 0.000663013 & & \\
\hline & GHR 13 & 31.5495 & TBP 13 & 22.45877618 & 9.090723817 & 0.001834085 & & \\
\hline & GHR 14 & 31.6187 & TBP 14 & 22.0093804 & 9.609319598 & 0.001280285 & & \\
\hline & GHR 15 & 31.987 & TBP 15 & 22.10227343 & 9.884726569 & 0.001057793 & & \\
\hline
\end{tabular}

Appendix Table 18: Q-PCR raw $\mathrm{C}_{\mathrm{T}}$ values and calculations for $\mathrm{GH}$ receptor mRNA abundance in MEC from Holstein milk cultured for $7 \mathrm{~d}$. 


\begin{tabular}{|c|c|c|c|c|c|c|c|c|}
\hline $\mathbf{T X}$ & Sample ID & $\mathbf{C}_{\mathbf{T}}$ & HKG ID & $\mathbf{C}_{\mathbf{T}}$ & $\Delta \Delta \mathbf{C}_{\mathbf{T}}$ & $2^{-\Delta \Delta C T}$ & Average & SEM \\
\hline \multirow{5}{*}{ 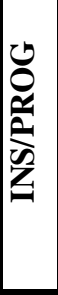 } & IGF-1 1 & 33.3659 & TBP 1 & 22.47289944 & 10.89300056 & 0.000525872 & \multirow{5}{*}{0.000524181} & \multirow{5}{*}{0.000203493} \\
\hline & IGF-1 2 & 32.3084 & TBP 2 & 22.46722422 & 9.841175779 & 0.001090212 & & \\
\hline & IGF-1 3 & 31.7706 & TBP 3 & 21.57255561 & 10.19804439 & 0.0008513 & & \\
\hline & IGF-1 4 & 35.544 & TBP 4 & 21.57362486 & 13.97037514 & $6.23014 \mathrm{E}-05$ & & \\
\hline & IGF-1 5 & 35.1754 & TBP 5 & 21.75510852 & 13.42029148 & $9.12199 \mathrm{E}-05$ & & \\
\hline \multirow{5}{*}{$\hat{\bar{a}}$} & IGF-1 6 & 33.5583 & TBP 6 & 22.13608466 & 11.42221534 & 0.000364393 & \multirow{5}{*}{0.000365843} & \multirow{5}{*}{0.000143484} \\
\hline & IGF-1 7 & 32.6163 & TBP 7 & 22.45249931 & 10.16380069 & 0.000871748 & & \\
\hline & IGF-1 8 & 32.8773 & TBP 8 & 21.6431689 & 11.2341311 & 0.000415135 & & \\
\hline & IGF-1 9 & 35.1887 & TBP 9 & 21.81917515 & 13.36952485 & 9.4487E-05 & & \\
\hline & IGF-1 10 & 35.1275 & TBP 10 & 21.57881884 & 13.54868116 & 8.34527E-05 & & \\
\hline \multirow{5}{*}{ 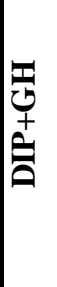 } & IGF-1 11 & 32.9106 & TBP 11 & 22.06155041 & 10.84904959 & 0.000542139 & \multirow{5}{*}{0.001840695} & \multirow{5}{*}{0.001422288} \\
\hline & IGF-1 12 & 32.9823 & TBP 12 & 22.17592414 & 10.80637586 & 0.000558415 & & \\
\hline & IGF-1 13 & 29.5131 & TBP 13 & 22.45877618 & 7.054323817 & 0.007523795 & & \\
\hline & IGF-1 14 & 34.3348 & TBP 14 & 22.0093804 & 12.3254196 & 0.00019484 & & \\
\hline & IGF-1 15 & 33.4478 & TBP 15 & 22.10227343 & 11.34552657 & 0.000384287 & & \\
\hline
\end{tabular}

Appendix Table 19: Q-PCR raw $\mathrm{C}_{\mathrm{T}}$ values and calculations for IGF-I mRNA abundance in MEC from Holstein milk cultured for $7 \mathrm{~d}$.

\begin{tabular}{|c|c|c|c|c|c|c|c|c|}
\hline $\mathbf{T X}$ & Sample ID & $\mathbf{C}_{\mathbf{T}}$ & HKG ID & $\mathbf{C}_{\mathbf{T}}$ & $\Delta \Delta \mathbf{C}_{\mathrm{T}}$ & $2^{-\Delta \Delta C T}$ & Average & SEM \\
\hline \multirow{5}{*}{ 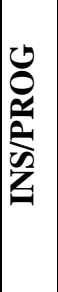 } & IGFBP3 1 & 22.1111 & TBP 1 & 22.47289944 & 0.361799438 & 0.778193353 & \multirow{5}{*}{0.504184184} & \multirow{5}{*}{0.083298338} \\
\hline & IGFBP3 2 & 21.69 & TBP 2 & 22.46722422 & 0.777224221 & 0.583488359 & & \\
\hline & IGFBP3 3 & 22.918 & TBP 3 & 21.57255561 & 1.345444386 & 0.393532752 & & \\
\hline & IGFBP3 4 & 22.6583 & TBP 4 & 21.57362486 & 1.084675143 & 0.471498425 & & \\
\hline & IGFBP3 5 & 23.5202 & TBP 5 & 21.75510852 & 1.765091477 & 0.294208029 & & \\
\hline \multirow{5}{*}{$\hat{\bar{\theta}}$} & IGFBP3 6 & 21.8865 & TBP 6 & 22.13608466 & 0.249584656 & 0.84113854 & \multirow{5}{*}{0.574123684} & \multirow{5}{*}{0.077782049} \\
\hline & IGFBP3 7 & 21.7177 & TBP 7 & 22.45249931 & 0.734799313 & 0.600901608 & & \\
\hline & IGFBP3 8 & 22.4257 & TBP 8 & 21.6431689 & 0.782531095 & 0.581345972 & & \\
\hline & IGFBP3 9 & 22.9201 & ТВР 9 & 21.81917515 & 1.100924846 & 0.466217529 & & \\
\hline & IGFBP3 10 & 22.9709 & TBP 10 & 21.57881884 & 1.392081157 & 0.381014773 & & \\
\hline \multirow{5}{*}{ 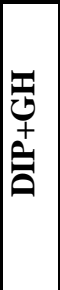 } & IGFBP3 11 & 20.9935 & TBP 11 & 22.06155041 & 1.068050408 & 0.47696311 & \multirow{5}{*}{0.57993335} & \multirow{5}{*}{0.075945437} \\
\hline & IGFBP3 12 & 21.4078 & TBP 12 & 22.17592414 & 0.768124137 & 0.587180459 & & \\
\hline & IGFBP3 13 & 22.7068 & TBP 13 & 22.45877618 & 0.248023817 & 0.842049053 & & \\
\hline & IGFBP3 14 & 22.7416 & TBP 14 & 22.0093804 & 0.732219598 & 0.601977055 & & \\
\hline & IGFBP3 15 & 23.4552 & TBP 15 & 22.10227343 & 1.352926569 & 0.391497074 & & \\
\hline
\end{tabular}

Appendix Table 20: Q-PCR raw $\mathrm{C}_{\mathrm{T}}$ values and calculations for IGFBP-3 mRNA abundance in MEC from Holstein milk cultured for $7 \mathrm{~d}$. 
Primary MEC from a Holstein cow (Table 21-25): raw qPCR values corresponding to results presented in Figure 8.

\begin{tabular}{|c|c|c|c|c|c|c|c|c|c|}
\hline & TX & Sample ID & $\mathbf{C}_{\mathbf{T}}$ & HKG ID & $\mathbf{C}_{\mathbf{T}}$ & $\Delta \Delta \mathbf{C}_{\mathrm{T}}$ & $2^{-\Delta \Delta C T}$ & Average & SEM \\
\hline & \multirow{5}{*}{ 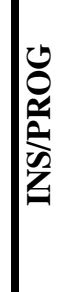 } & ALAC 1 & 37.8121 & POL1 1 & 22.1496 & 15.6625 & $1.92805 \mathrm{E}-05$ & \multirow{5}{*}{0.000102162} & \multirow{5}{*}{$2.89675 \mathrm{E}-05$} \\
\hline & & ALAC 2 & 35.0814 & POL1 2 & 21.5752 & 13.5062 & $8.59466 \mathrm{E}-05$ & & \\
\hline & & ALAC 3 & 35.3206 & POL1 3 & 22.111 & 13.2096 & 0.000105564 & & \\
\hline & & ALAC 4 & 35.3557 & POL1 4 & 22.0638 & 13.2919 & 9.97102E-05 & & \\
\hline & & ALAC 5 & 34.3295 & POL1 5 & 22.044 & 12.2855 & 0.000200307 & & \\
\hline \multirow{10}{*}{$\underset{\sim}{\sim}$} & \multirow{5}{*}{$\hat{\bar{\theta}}$} & ALAC 6 & 35.0221 & POL1 6 & 22.7134 & 12.3087 & 0.000197112 & \multirow{5}{*}{0.000401239} & \multirow{5}{*}{0.00014815} \\
\hline & & ALAC 7 & 35.0082 & POL1 7 & 21.4217 & 13.5865 & $8.12935 \mathrm{E}-05$ & & \\
\hline & & ALAC 8 & 35.7172 & POL1 8 & 23.8427 & 11.8745 & 0.00026633 & & \\
\hline & & ALAC 9 & 32.1319 & POL1 9 & 22.0195 & 10.1124 & 0.000903367 & & \\
\hline & & ALAC 10 & 32.9837 & POL1 10 & 22.1765 & 10.8072 & 0.000558096 & & \\
\hline & \multirow{5}{*}{ 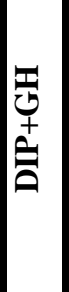 } & ALAC 11 & 33.9591 & POL1 11 & 24.0026 & 9.9565 & 0.001006456 & \multirow{5}{*}{0.000282145} & \multirow{5}{*}{0.00018305} \\
\hline & & ALAC 12 & 35.1085 & POL1 12 & 22.4189 & 12.6896 & 0.000151373 & & \\
\hline & & ALAC 13 & 37.0585 & POL1 13 & 21.7222 & 15.3363 & $2.41721 \mathrm{E}-05$ & & \\
\hline & & ALAC 14 & 35.8989 & POL1 14 & 21.9122 & 13.9867 & $6.16004 \mathrm{E}-05$ & & \\
\hline & & ALAC 15 & 35.1477 & POL1 15 & 22.6009 & 12.5468 & 0.000167123 & & \\
\hline \multirow{10}{*}{$\underset{\nabla}{\varpi}$} & \multirow{5}{*}{$\hat{\bar{\theta}}$} & ALAC 16 & 34.6513 & POL1 16 & 22.3455 & 12.3058 & 0.000197508 & \multirow{5}{*}{0.00022833} & \multirow{5}{*}{ 3.22772E-05 } \\
\hline & & ALAC 17 & 34.0734 & POL1 17 & 22.1725 & 11.9009 & 0.0002615 & & \\
\hline & & ALAC 18 & 34.4364 & POL1 18 & 21.9373 & 12.4991 & 0.000172741 & & \\
\hline & & ALAC 19 & 34.1859 & POL1 19 & 22.6033 & 11.5826 & 0.000326054 & & \\
\hline & & ALAC 20 & 35.2209 & POL1 20 & 22.8117 & 12.4092 & 0.000183848 & & \\
\hline & \multirow{5}{*}{ 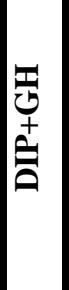 } & ALAC 21 & 35.1489 & POL1 21 & 22.7896 & 12.3593 & 0.000190318 & \multirow{5}{*}{0.000280086} & \multirow{5}{*}{0.000146367} \\
\hline & & ALAC 22 & 34.0872 & POL1 22 & 21.7237 & 12.3635 & 0.000189765 & & \\
\hline & & ALAC 23 & 35.7661 & POL1 23 & 21.9127 & 13.8534 & $6.75633 \mathrm{E}-05$ & & \\
\hline & & ALAC 24 & 35.3991 & POL1 24 & 22.0464 & 13.3527 & 9.55954E-05 & & \\
\hline & & ALAC 25 & 34.3812 & POL1 25 & 24.1931 & 10.1881 & 0.000857188 & & \\
\hline
\end{tabular}

Appendix Table 21: Q-PCR raw $\mathrm{C}_{\mathrm{T}}$ values and calculations for $\alpha$-lactalbumin mRNA abundance in primary MEC from a Holstein cow cultured for $2 \mathrm{~d}$ and $4 \mathrm{~d}$. 


\begin{tabular}{|c|c|c|c|c|c|c|c|c|c|}
\hline & $\mathbf{T X}$ & Sample ID & $\mathbf{C}_{\mathbf{T}}$ & HKG ID & $\mathbf{C}_{\mathbf{T}}$ & $\Delta \Delta \mathbf{C}_{\mathbf{T}}$ & $2^{-\Delta \Delta C T}$ & Average & SEM \\
\hline & \multirow{5}{*}{ 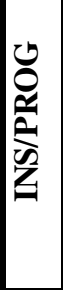 } & CAS 1 & 38.554 & POL1 1 & 22.1496 & 16.4044 & $1.15288 \mathrm{E}-05$ & \multirow{5}{*}{$6.67216 \mathrm{E}-06$} & \multirow{5}{*}{$1.94398 \mathrm{E}-06$} \\
\hline & & CAS 2 & 40.8805 & POL1 2 & 21.5752 & 19.3053 & 1.54357E-06 & & \\
\hline & & CAS 3 & 39.1396 & POL1 3 & 22.111 & 17.0286 & 7.47964E-06 & & \\
\hline & & CAS 4 & 38.6832 & POL1 4 & 22.0638 & 16.6194 & 9.93258E-06 & & \\
\hline & & CAS 5 & 40.4514 & POL1 5 & 22.044 & 18.4074 & 2.87621E-06 & & \\
\hline \multirow{9}{*}{ 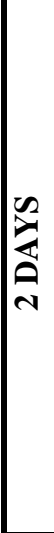 } & \multirow{4}{*}{$\hat{\bar{\theta}}$} & CAS 6 & 43.3289 & POL1 6 & 22.7134 & 20.6155 & $6.22467 \mathrm{E}-07$ & \multirow{4}{*}{$7.86088 \mathrm{E}-06$} & \multirow{4}{*}{ 4.69617E-06 } \\
\hline & & CAS 7 & 40.0032 & POL1 7 & 21.4217 & 18.5815 & 2.54924E-06 & & \\
\hline & & CAS 8 & 40.9918 & POL1 8 & 23.8427 & 17.1491 & 6.88029E-06 & & \\
\hline & & CAS 9 & 37.5321 & POL1 9 & 22.0195 & 15.5126 & 2.13915E-05 & & \\
\hline & \multirow{5}{*}{$\begin{array}{l}\overline{7} \\
\overline{5} \\
+ \\
\overline{0}\end{array}$} & CAS 11 & 47.2617 & POL1 11 & 24.0026 & 23.2591 & 9.96124E-08 & \multirow{5}{*}{$6.60311 \mathrm{E}-06$} & \multirow{5}{*}{ 4.06207E-06 } \\
\hline & & CAS 12 & 37.957 & POL1 12 & 22.4189 & 15.5381 & $2.10168 \mathrm{E}-05$ & & \\
\hline & & CAS 13 & 41.6762 & POL1 13 & 21.7222 & 19.954 & 9.84572E-07 & & \\
\hline & & CAS 14 & 38.4875 & POL1 14 & 21.9122 & 16.5753 & $1.02409 \mathrm{E}-05$ & & \\
\hline & & CAS 15 & 43.1023 & POL1 15 & 22.6009 & 20.5014 & $6.73696 \mathrm{E}-07$ & & \\
\hline \multirow{9}{*}{$\underset{\sigma}{\infty}$} & \multirow{5}{*}{$\hat{\bar{\rho}}$} & CAS 16 & 36.9696 & POL1 16 & 22.3455 & 14.6241 & 3.96011E-05 & \multirow{5}{*}{ 1.17798E-05 } & \multirow{5}{*}{ 8.14008E-06 } \\
\hline & & CAS 17 & 45.906 & POL1 17 & 22.1725 & 23.7335 & 7.16976E-08 & & \\
\hline & & CAS 18 & 42.227 & POL1 18 & 21.9373 & 20.2897 & 7.80174E-07 & & \\
\hline & & CAS 19 & 39.838 & POL1 19 & 22.6033 & 17.2347 & $6.48393 \mathrm{E}-06$ & & \\
\hline & & CAS 20 & 39.1629 & POL1 20 & 22.8117 & 16.3512 & $1.19618 \mathrm{E}-05$ & & \\
\hline & \multirow{4}{*}{ 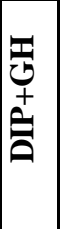 } & CAS 21 & 44.7949 & POL1 21 & 22.7896 & 22.0053 & $2.37544 \mathrm{E}-07$ & \multirow{4}{*}{ 1.15479E-05 } & \multirow{4}{*}{ 7.81649E-06 } \\
\hline & & CAS 22 & 36.6001 & POL1 22 & 21.7237 & 14.8764 & $3.32474 \mathrm{E}-05$ & & \\
\hline & & CAS 24 & 48.2958 & POL1 24 & 22.0464 & 26.2494 & $1.25355 \mathrm{E}-08$ & & \\
\hline & & CAS 25 & 40.4586 & POL1 25 & 24.1931 & 16.2655 & $1.26939 \mathrm{E}-05$ & & \\
\hline
\end{tabular}

Appendix Table 22: Q-PCR raw $C_{T}$ values and calculations for $\alpha_{\mathrm{s} 1}$-casein mRNA abundance in primary MEC from a Holstein cow cultured for $2 \mathrm{~d}$ and $4 \mathrm{~d}$. 


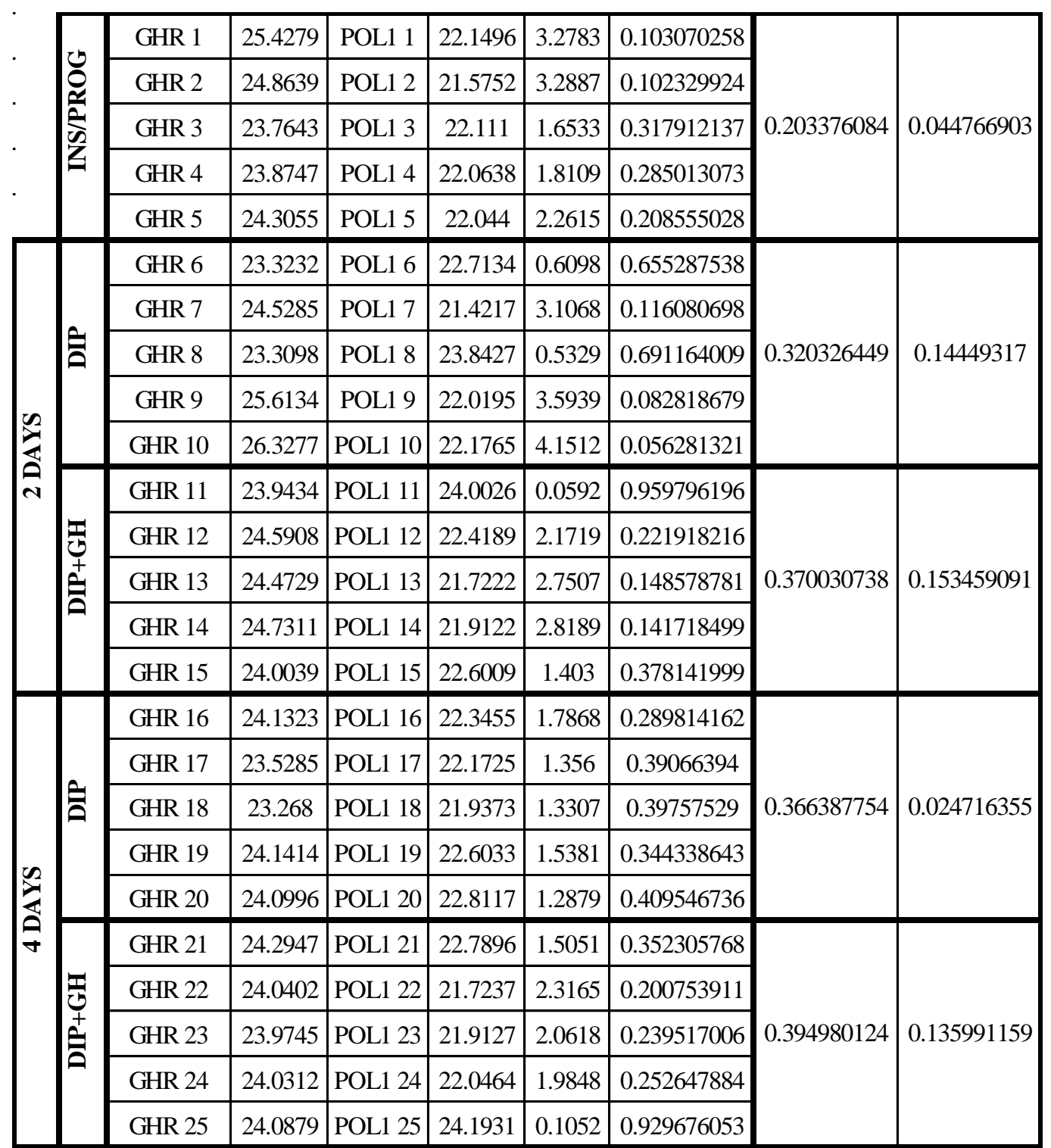

Appendix Table 23: Q-PCR raw $\mathrm{C}_{\mathrm{T}}$ values and calculations for $\mathrm{GH}$ receptor mRNA abundance in primary MEC from a Holstein cow cultured for $2 \mathrm{~d}$ and $4 \mathrm{~d}$. 


\begin{tabular}{|c|c|c|c|c|c|c|c|c|c|}
\hline & $\mathrm{TX}$ & Sample ID & $\mathbf{C}_{\mathrm{T}}$ & HKG ID & $\mathbf{C}_{\mathbf{T}}$ & $\Delta \Delta \mathrm{C}_{\mathrm{T}}$ & $2^{-\Delta \Delta C T}$ & Average & SEM \\
\hline \multirow{4}{*}{ 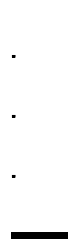 } & \multirow{4}{*}{ 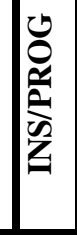 } & IGF1 1 & 30.859 & POL1 1 & 22.1496 & 8.7094 & 0.002388963 & \multirow{4}{*}{0.002448109} & \multirow{4}{*}{0.0003281} \\
\hline & & IGF1 2 & 30.916 & POL1 2 & 21.5752 & 9.3408 & 0.001542194 & & \\
\hline & & IGF1 3 & 30.5103 & POL1 3 & 22.111 & 8.3993 & 0.002961821 & & \\
\hline & & IGF1 4 & 30.4938 & POL1 4 & 22.0638 & 8.43 & 0.00289946 & & \\
\hline \multirow{9}{*}{ 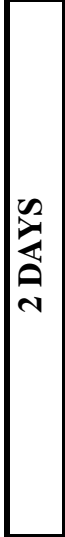 } & \multirow{4}{*}{$\hat{\bar{\theta}}$} & IGF1 6 & 31.3717 & POL1 6 & 22.7134 & 8.6583 & 0.002475096 & \multirow{4}{*}{0.003799523} & \multirow{4}{*}{0.0012174} \\
\hline & & IGF1 7 & 29.9586 & POL1 7 & 21.4217 & 8.5369 & 0.002692384 & & \\
\hline & & IGF1 8 & 31.169 & POL1 8 & 23.8427 & 7.3263 & 0.006231089 & & \\
\hline & & IGF1 9 & 30.0339 & POL1 9 & 22.0195 & 8.0144 & 0.003867454 & & \\
\hline & \multirow{5}{*}{$\begin{array}{l}\mathbf{T} \\
0 \\
+ \\
\hat{0}\end{array}$} & IGF1 11 & 31.3547 & POL1 11 & 24.0026 & 7.3521 & 0.006120648 & \multirow{5}{*}{0.002496836} & \multirow{5}{*}{0.000946923} \\
\hline & & IGF1 12 & 31.9041 & POL1 12 & 22.4189 & 9.4852 & 0.001395309 & & \\
\hline & & IGF1 13 & 31.3803 & POL1 13 & 21.7222 & 9.6581 & 0.001237719 & & \\
\hline & & IGF1 14 & 31.7548 & POL1 14 & 21.9122 & 9.8426 & 0.001089136 & & \\
\hline & & IGF1 15 & 31.1654 & POL1 15 & 22.6009 & 8.5645 & 0.002641366 & & \\
\hline \multirow{10}{*}{$\frac{\mathscr{2}}{2}$} & \multirow{5}{*}{$\hat{\bar{\theta}}$} & IGF1 16 & 31.3141 & POL1 16 & 22.3455 & 8.9686 & 0.0019961 & \multirow{5}{*}{0.003552774} & \multirow{5}{*}{0.00076245} \\
\hline & & IGF1 17 & 30.7546 & POL1 17 & 22.1725 & 8.5821 & 0.002609339 & & \\
\hline & & IGF1 18 & 30.3076 & POL1 18 & 21.9373 & 8.3703 & 0.003021959 & & \\
\hline & & IGF1 19 & 30.0295 & POL1 19 & 22.6033 & 7.4262 & 0.005814214 & & \\
\hline & & IGF1 20 & 30.6657 & POL1 20 & 22.8117 & 7.854 & 0.004322255 & & \\
\hline & \multirow{5}{*}{$\begin{array}{l}\mathbf{T} \\
0 \\
+ \\
\tilde{0}\end{array}$} & IGF1 21 & 30.6987 & POL1 21 & 22.7896 & 7.9091 & 0.004160291 & \multirow{5}{*}{0.003097148} & \multirow{5}{*}{0.00080810} \\
\hline & & IGF1 22 & 29.9946 & POL1 22 & 21.7237 & 8.2709 & 0.003237509 & & \\
\hline & & IGF1 23 & 31.4874 & POL1 23 & 21.9127 & 9.5747 & 0.001311379 & & \\
\hline & & IGF1 24 & 31.6112 & POL1 24 & 22.0464 & 9.5648 & 0.001320408 & & \\
\hline & & IGF1 25 & 31.711 & POL1 25 & 24.1931 & 7.5179 & 0.005456154 & & \\
\hline
\end{tabular}

Appendix Table 24: Q-PCR raw $\mathrm{C}_{\mathrm{T}}$ values and calculations for IGF-I mRNA abundance in primary MEC from a Holstein cow cultured for $2 \mathrm{~d}$ and $4 \mathrm{~d}$. 


\begin{tabular}{|c|c|c|c|c|c|c|c|c|c|}
\hline & $\mathbf{T X}$ & Sample ID & $\mathbf{C}_{\mathbf{T}}$ & HKG ID & $\mathbf{C}_{\mathbf{T}}$ & $\Delta \Delta \mathbf{C}_{\mathbf{T}}$ & $2^{-\Delta \Delta C T}$ & Average & SEM \\
\hline & \multirow{5}{*}{ 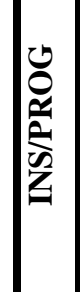 } & IGFBP3 1 & 25.2027 & POL1 1 & 22.1496 & 3.0531 & 0.120482874 & \multirow{5}{*}{0.086597734} & \multirow{5}{*}{0.01028331} \\
\hline & & IGFBP3 2 & 25.1948 & POL1 2 & 21.5752 & 3.6196 & 0.08135642 & & \\
\hline & & IGFBP3 3 & 26.1638 & POL1 3 & 22.111 & 4.0528 & 0.060253965 & & \\
\hline & & IGFBP3 4 & 25.8117 & POL1 4 & 22.0638 & 3.7479 & 0.074433712 & & \\
\hline & & IGFBP3 5 & 25.4179 & POL1 5 & 22.044 & 3.3739 & 0.096461697 & & \\
\hline \multirow{10}{*}{ 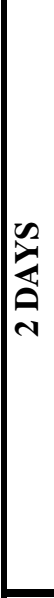 } & \multirow{5}{*}{$\hat{\bar{a}}$} & IGFBP3 6 & 25.8435 & POL1 6 & 22.7134 & 3.1301 & 0.114221014 & \multirow{5}{*}{0.363945544} & \multirow{5}{*}{0.154895353} \\
\hline & & IGFBP3 7 & 23.1833 & POL1 7 & 21.4217 & 1.7616 & 0.294920906 & & \\
\hline & & IGFBP3 8 & 23.8917 & POL1 8 & 23.8427 & 0.049 & 0.966606097 & & \\
\hline & & IGFBP3 9 & 20.2331 & POL1 9 & 22.0195 & -1.7864 & 0.289894527 & & \\
\hline & & IGFBP3 10 & 19.4783 & POL1 10 & 22.1765 & -2.6982 & 0.154085178 & & \\
\hline & \multirow{5}{*}{ 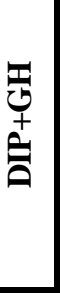 } & IGFBP3 11 & 26.7944 & POL1 11 & 24.0026 & 2.7918 & 0.144405741 & \multirow{5}{*}{0.134156422} & \multirow{5}{*}{0.032723296} \\
\hline & & IGFBP3 12 & 24.457 & POL1 12 & 22.4189 & 2.0381 & 0.24348419 & & \\
\hline & & IGFBP3 13 & 25.7321 & POL1 13 & 21.7222 & 4.0099 & 0.062072583 & & \\
\hline & & IGFBP3 14 & 25.719 & POL1 14 & 21.9122 & 3.8068 & 0.071456051 & & \\
\hline & & IGFBP3 15 & 25.344 & POL1 15 & 22.6009 & 2.7431 & 0.149363547 & & \\
\hline \multirow{10}{*}{$\underset{\nabla}{2}$} & \multirow{5}{*}{$\hat{\bar{\theta}}$} & IGFBP3 16 & 22.8383 & POL1 16 & 22.3455 & 0.4928 & 0.710644531 & \multirow{5}{*}{0.468753614} & \multirow{5}{*}{0.125223136} \\
\hline & & IGFBP3 17 & 24.6386 & POL1 17 & 22.1725 & 2.4661 & 0.180979727 & & \\
\hline & & IGFBP3 18 & 23.9245 & POL1 18 & 21.9373 & 1.9872 & 0.25222794 & & \\
\hline & & IGFBP3 19 & 22.127 & POL1 19 & 22.6033 & -0.4763 & 0.718818777 & & \\
\hline & & IGFBP3 20 & 23.8673 & POL1 20 & 22.8117 & 1.0556 & 0.481097097 & & \\
\hline & \multirow{5}{*}{$\begin{array}{l}\frac{\pi}{5} \\
\stackrel{+}{0} \\
\hat{0}\end{array}$} & IGFBP3 21 & 24.4714 & POL1 21 & 22.7896 & 1.6818 & 0.311693505 & \multirow{5}{*}{0.209613902} & \multirow{5}{*}{0.030064775} \\
\hline & & IGFBP3 22 & 24.2606 & POL1 22 & 21.7237 & 2.5369 & 0.172312588 & & \\
\hline & & IGFBP3 23 & 24.1365 & POL1 23 & 21.9127 & 2.2238 & 0.214076746 & & \\
\hline & & IGFBP3 24 & 24.9774 & POL1 24 & 22.0464 & 2.931 & 0.131123666 & & \\
\hline & & IGFBP3 25 & 26.385 & POL1 25 & 24.1931 & 2.1919 & 0.218863002 & & \\
\hline
\end{tabular}

Appendix Table 25: Q-PCR raw $\mathrm{C}_{\mathrm{T}}$ values and calculations for IGFBP-3 mRNA abundance in primary MEC from a Holstein cow cultured for $2 \mathrm{~d}$ and $4 \mathrm{~d}$. 
Primary MEC from a Jersey cow (Table 26-30): raw qPCR values corresponding to results presented in Figure 9.

\begin{tabular}{|c|c|c|c|c|c|c|c|c|c|}
\hline & $\mathbf{T X}$ & Sample ID & $\mathbf{C}_{\mathbf{T}}$ & HKG ID & $\mathbf{C}_{\mathbf{T}}$ & $\Delta \Delta \mathbf{C}_{\mathrm{T}}$ & $2^{-\Delta \Delta C T}$ & Average & SEM \\
\hline & & ALAC 1 & 34.5856 & POL1 1 & 21.6008 & 12.9848 & 0.000123363 & & \\
\hline & 0 & ALAC 2 & 32.9151 & POL1 2 & 21.5417 & 11.3734 & 0.000376934 & & \\
\hline & $\frac{1}{5}$ & ALAC 3 & 33.8853 & POL1 3 & 22.12 & 11.7653 & 0.000287271 & 0.000211492 & 5.24183E-05 \\
\hline & & ALAC 4 & 33.5719 & POL1 4 & 21.0434 & 12.5285 & 0.000169257 & & \\
\hline & & ALAC 5 & 34.8125 & POL1 5 & 21.5339 & 13.2786 & 0.000100634 & & \\
\hline & & ALAC 6 & 33.3643 & POL1 6 & 21.7818 & 11.5825 & 0.000326077 & & \\
\hline & & ALAC 7 & 33.937 & POL1 7 & 21.8675 & 12.0695 & 0.000232658 & & \\
\hline & $\bar{\theta}$ & ALAC 8 & 35.666 & POL1 8 & 22.0168 & 13.6492 & 7.78362E-05 & 0.000202165 & $5.18116 \mathrm{E}-05$ \\
\hline & & ALAC 9 & 33.1407 & POL1 9 & 21.393 & 11.7477 & 0.000290797 & & \\
\hline$\sum$ & & ALAC 10 & 34.791 & POL1 10 & 21.2424 & 13.5486 & 8.34574E-05 & & \\
\hline$\vec{v}$ & & ALAC 11 & 33.9952 & POL1 11 & 21.1259 & 12.8693 & 0.000133646 & & \\
\hline & 考 & ALAC 12 & 33.5492 & POL1 12 & 21.7264 & 11.8228 & 0.000276047 & & \\
\hline & $\hat{\sigma}^{+}$ & ALAC 13 & 33.1541 & POL1 13 & 21.7135 & 11.4406 & 0.000359779 & 0.00025843 & $5.15797 \mathrm{E}-05$ \\
\hline & & ALAC 14 & 33.7221 & POL1 14 & 22.3513 & 11.3708 & 0.000377614 & & \\
\hline & & ALAC 15 & 34.6979 & POL1 15 & 21.9469 & 12.751 & 0.000145066 & & \\
\hline & & ALAC 16 & 33.9162 & POL1 16 & 22.3855 & 11.5307 & 0.000337997 & & \\
\hline & & ALAC 17 & 33.122 & POL1 17 & 21.9234 & 11.1986 & 0.000425486 & & \\
\hline & $\bar{\theta}$ & ALAC 18 & 34.9406 & POL1 18 & 21.2639 & 13.6767 & $7.63665 \mathrm{E}-05$ & 0.000227131 & 7.54479E-05 \\
\hline & & ALAC 19 & 34.3869 & POL1 19 & 21.1321 & 13.2548 & 0.000102308 & & \\
\hline$\sum$ & & ALAC 20 & 34.0648 & POL1 20 & 21.7294 & 12.3354 & 0.000193497 & & \\
\hline$\nabla$ & & ALAC 21 & 32.9287 & POL1 21 & 22.1445 & 10.7842 & 0.000567064 & & \\
\hline & 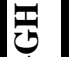 & ALAC 22 & 34.0601 & POL1 22 & 20.822 & 13.2381 & 0.000103499 & & \\
\hline & $\hat{\theta}^{+}$ & ALAC 23 & 34.6318 & POL1 23 & 21.1386 & 13.4932 & $8.67246 \mathrm{E}-05$ & 0.000235285 & 8.68794E-05 \\
\hline & & ALAC 24 & 34.3308 & POL1 24 & 22.0556 & 12.2752 & 0.000201742 & & \\
\hline & & ALAC 25 & 34.0154 & POL1 25 & 21.848 & 12.1674 & 0.000217394 & & \\
\hline
\end{tabular}

Appendix Table 26: Q-PCR raw $\mathrm{C}_{\mathrm{T}}$ values and calculations for $\alpha$-lactalbumin mRNA abundance in primary MEC from a Jersey cow cultured for $2 \mathrm{~d}$ and $4 \mathrm{~d}$. 


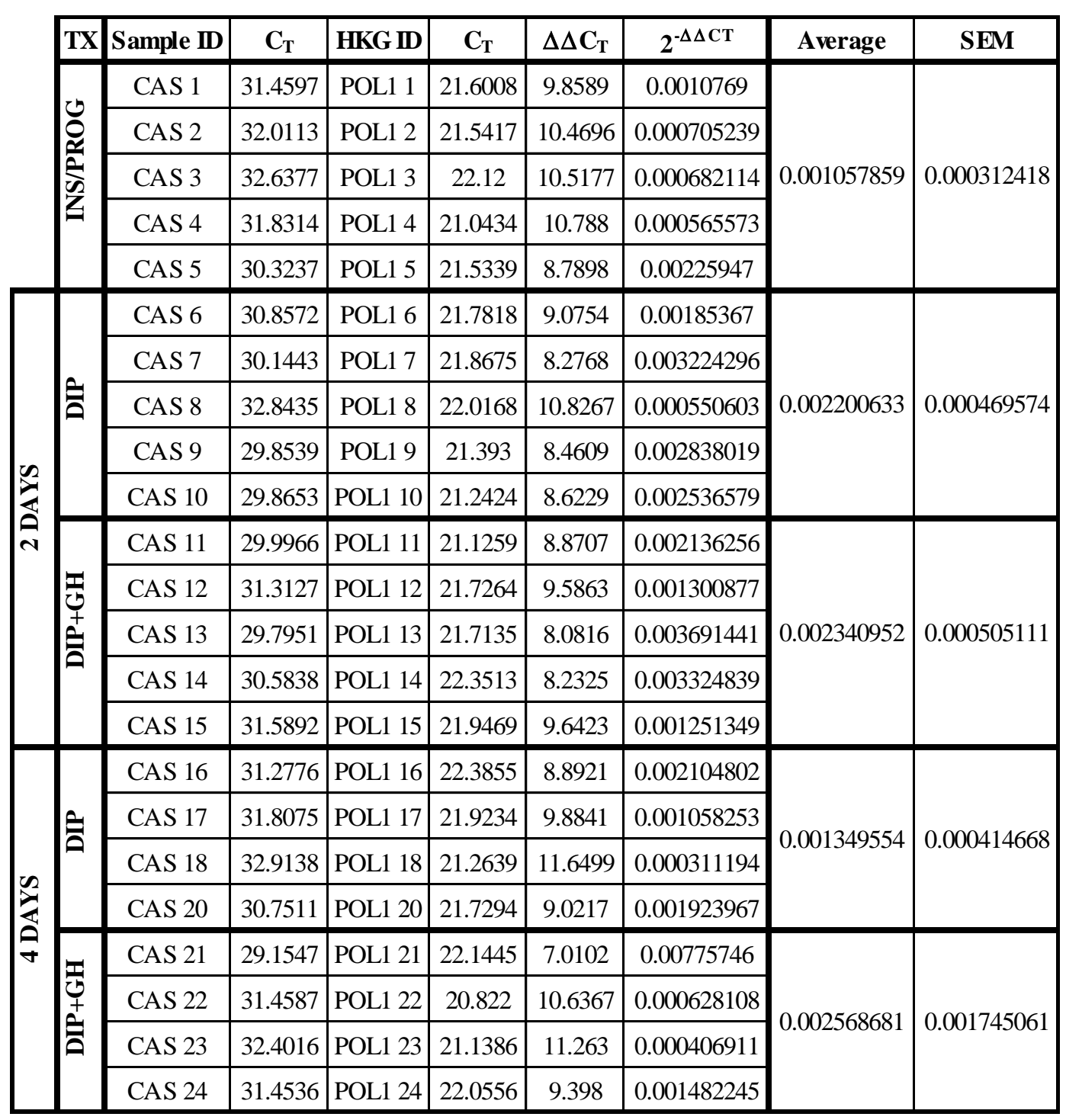

Appendix Table 27: Q-PCR raw $C_{T}$ values and calculations for $\alpha_{\mathrm{S} 1}$-casein mRNA abundance in primary MEC from a Jersey cow cultured for $2 \mathrm{~d}$ and $4 \mathrm{~d}$. 


\begin{tabular}{|c|c|c|c|c|c|c|c|c|c|}
\hline & TX & Sample ID & $\mathbf{C}_{\mathbf{T}}$ & HKG ID & $\mathbf{C}_{\mathbf{T}}$ & $\Delta \Delta \mathbf{C}_{\mathrm{T}}$ & $2^{-\Delta \Delta C T}$ & Average & SEM \\
\hline & \multirow{5}{*}{ 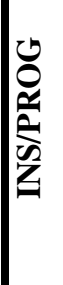 } & GHR 1 & 25.4218 & POL1 1 & 21.6008 & 3.821 & 0.070756181 & \multirow{5}{*}{0.051652521} & \multirow{5}{*}{0.005175248} \\
\hline & & GHR 2 & 26.0969 & POL1 2 & 21.5417 & 4.5552 & 0.042535169 & & \\
\hline & & GHR 3 & 26.4875 & POL1 3 & 22.12 & 4.3675 & 0.048445283 & & \\
\hline & & GHR 4 & 25.2684 & POL1 4 & 21.0434 & 4.225 & 0.053474689 & & \\
\hline & & GHR 5 & 26.0717 & POL1 5 & 21.5339 & 4.5378 & 0.043051282 & & \\
\hline \multirow{10}{*}{ 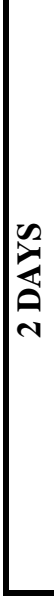 } & \multirow{5}{*}{$\hat{\bar{\alpha}}$} & GHR 6 & 25.4046 & POL1 6 & 21.7818 & 3.6228 & 0.081176165 & \multirow{5}{*}{0.072710057} & \multirow{5}{*}{0.010764663} \\
\hline & & GHR 7 & 25.0794 & POL1 7 & 21.8675 & 3.2119 & 0.107924925 & & \\
\hline & & GHR 8 & 25.8172 & POL1 8 & 22.0168 & 3.8004 & 0.071773745 & & \\
\hline & & GHR 9 & 25.4984 & POL1 9 & 21.393 & 4.1054 & 0.058096699 & & \\
\hline & & GHR 10 & 25.7299 & POL1 10 & 21.2424 & 4.4875 & 0.044578751 & & \\
\hline & \multirow{5}{*}{ 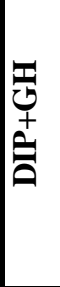 } & GHR 11 & 24.733 & POL1 11 & 21.1259 & 3.6071 & 0.082064382 & \multirow{5}{*}{0.19177127} & \multirow{5}{*}{0.04091166} \\
\hline & & GHR 12 & 24.6731 & POL1 12 & 21.7264 & 2.9467 & 0.129704461 & & \\
\hline & & GHR 13 & 24.1415 & POL1 13 & 21.7135 & 2.428 & 0.185822873 & & \\
\hline & & GHR 14 & 24.0396 & POL1 14 & 22.3513 & 1.6883 & 0.310292343 & & \\
\hline & & GHR 15 & 23.9413 & POL1 15 & 21.9469 & 1.9944 & 0.250972292 & & \\
\hline \multirow{10}{*}{ 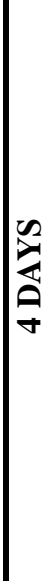 } & \multirow{5}{*}{$\hat{\bar{\theta}}$} & GHR 16 & 25.1113 & POL1 16 & 22.3855 & 2.7258 & 0.151165414 & \multirow{5}{*}{0.081900973} & \multirow{5}{*}{0.024898724} \\
\hline & & GHR 17 & 25.0513 & POL1 17 & 21.9234 & 3.1279 & 0.114395325 & & \\
\hline & & GHR 18 & 25.2565 & POL1 18 & 21.2639 & 3.9926 & 0.062821404 & & \\
\hline & & GHR 19 & 25.3844 & POL1 19 & 21.1321 & 4.2523 & 0.052472306 & & \\
\hline & & GHR 20 & 26.8547 & POL1 20 & 21.7294 & 5.1253 & 0.028650418 & & \\
\hline & \multirow{5}{*}{ 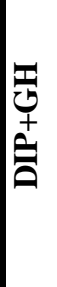 } & GHR 21 & 24.3259 & POL1 21 & 22.1445 & 2.1814 & 0.220461708 & \multirow{5}{*}{0.098989872} & \multirow{5}{*}{0.036827619} \\
\hline & & GHR 22 & 24.7417 & POL1 22 & 20.822 & 3.9197 & 0.066077367 & & \\
\hline & & GHR 23 & 25.3985 & POL1 23 & 21.1386 & 4.2599 & 0.052196613 & & \\
\hline & & GHR 24 & 25.8792 & POL1 24 & 22.0556 & 3.8236 & 0.070628781 & & \\
\hline & & GHR 25 & 25.3945 & POL1 25 & 21.848 & 3.5465 & 0.085584895 & & \\
\hline
\end{tabular}

Appendix Table 28: Q-PCR raw $\mathrm{C}_{\mathrm{T}}$ values and calculations for $\mathrm{GH}$ receptor $\mathrm{mRNA}$ abundance in primary MEC from a Jersey cow cultured for $2 \mathrm{~d}$ and $4 \mathrm{~d}$. 


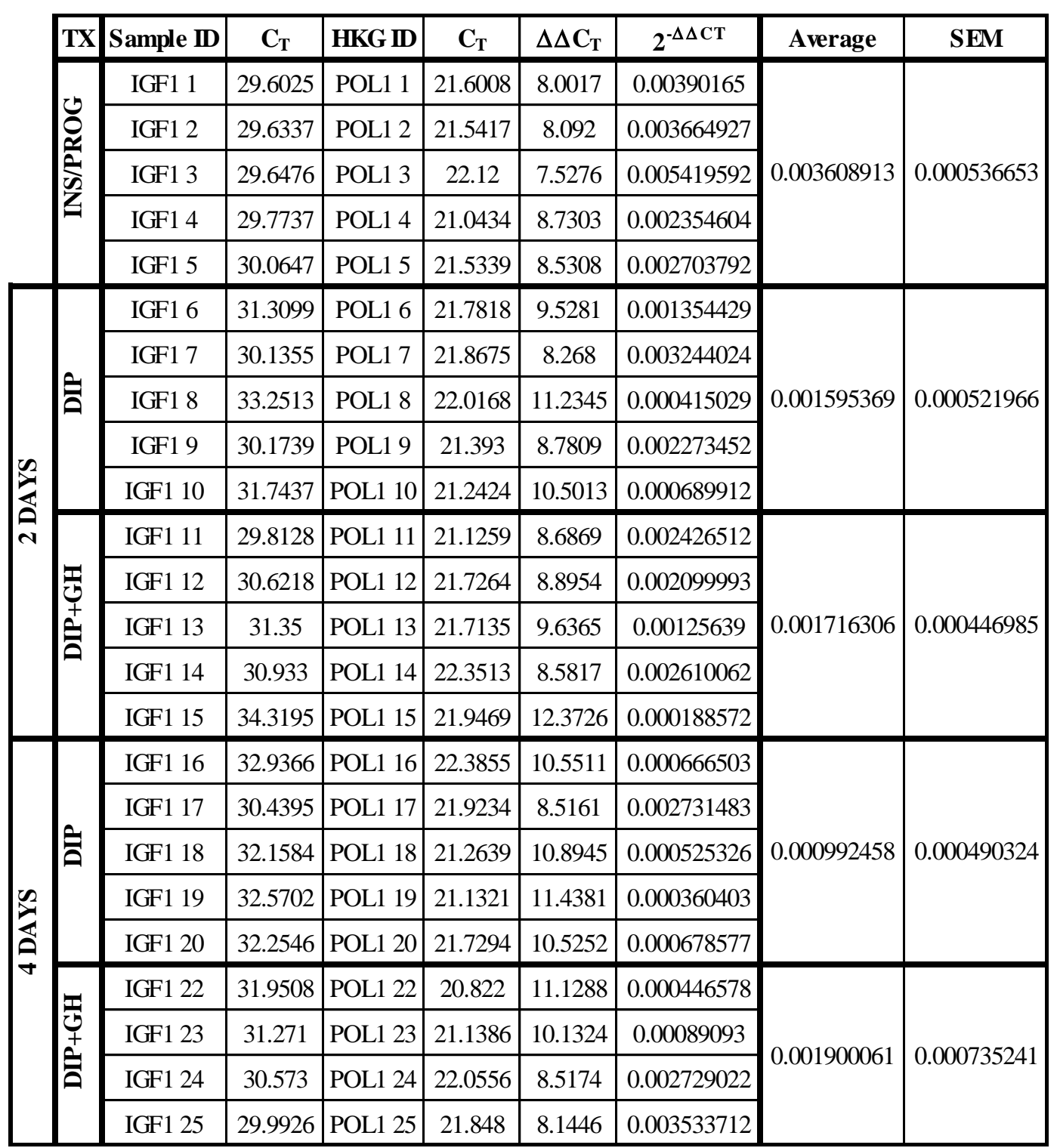

Appendix Table 29: Q-PCR raw $\mathrm{C}_{\mathrm{T}}$ values and calculations for IGF-I mRNA abundance in primary MEC from a Jersey cow cultured for $2 \mathrm{~d}$ and $4 \mathrm{~d}$. 


\begin{tabular}{|c|c|c|c|c|c|c|c|c|c|}
\hline & TX & Sample ID & $\mathbf{C}_{\mathbf{T}}$ & HKG ID & $\mathbf{C}_{\mathbf{T}}$ & $\Delta \Delta \mathbf{C}_{\mathbf{T}}$ & $2^{-\Delta \Delta C T}$ & Average & SEM \\
\hline & \multirow{5}{*}{$\begin{array}{l}0 \\
\frac{1}{2} \\
\frac{1}{2} \\
\frac{1}{Z}\end{array}$} & IGFBP3 1 & 26.3767 & POL1 1 & 21.6008 & 4.7759 & 0.036501511 & \multirow{5}{*}{0.039140462} & \multirow{5}{*}{0.001811193} \\
\hline & & IGFBP3 2 & 26.4466 & POL1 2 & 21.5417 & 4.9049 & 0.033379358 & & \\
\hline & & IGFBP3 3 & 26.7508 & POL1 3 & 22.12 & 4.6308 & 0.040363637 & & \\
\hline & & IGFBP3 4 & 25.5961 & POL1 4 & 21.0434 & 4.5527 & 0.042608941 & & \\
\hline & & IGFBP3 5 & 26.2400 & POL1 5 & 21.5339 & 4.7061 & 0.038310934 & & \\
\hline \multirow{9}{*}{$\frac{\Omega}{\sqrt{2}}$} & \multirow{4}{*}{$\hat{\bar{a}}$} & IGFBP3 6 & 26.3926 & POL1 6 & 21.7818 & 4.6108 & 0.040927093 & \multirow{4}{*}{0.041659423} & \multirow{4}{*}{0.013680801} \\
\hline & & IGFBP3 7 & 27.4488 & POL1 7 & 21.8675 & 5.5813 & 0.020886289 & & \\
\hline & & IGFBP3 8 & 25.6509 & POL1 8 & 22.0168 & 3.6341 & 0.080542831 & & \\
\hline & & IGFBP3 10 & 26.6064 & POL1 10 & 21.2424 & 5.364 & 0.024281477 & & \\
\hline & \multirow{5}{*}{$\begin{array}{l}\frac{\pi}{0} \\
+ \\
\hat{0}\end{array}$} & IGFBP3 11 & 29.3348 & POL1 11 & 21.1259 & 8.2089 & 0.003379674 & \multirow{5}{*}{0.04887478} & \multirow{5}{*}{0.017196604} \\
\hline & & IGFBP3 12 & 26.0112 & POL1 12 & 21.7264 & 4.2848 & 0.051303462 & & \\
\hline & & IGFBP3 13 & 24.9722 & POL1 13 & 21.7135 & 3.2587 & 0.104480094 & & \\
\hline & & IGFBP3 14 & 27.7126 & POL1 14 & 22.3513 & 5.3613 & 0.024326962 & & \\
\hline & & IGFBP3 15 & 25.9847 & POL1 15 & 21.9469 & 4.0378 & 0.060883706 & & \\
\hline \multirow{8}{*}{$\underset{d}{\mathscr{a}}$} & \multirow{4}{*}{$\hat{\bar{\theta}}$} & IGFBP3 17 & 26.6946 & POL1 17 & 21.9234 & 4.7712 & 0.036620619 & \multirow{4}{*}{0.125632681} & \multirow{4}{*}{0.045810735} \\
\hline & & IGFBP3 18 & 23.8805 & POL1 18 & 21.2639 & 2.6166 & 0.163051543 & & \\
\hline & & IGFBP3 19 & 23.2112 & POL1 19 & 21.1321 & 2.0791 & 0.236662003 & & \\
\hline & & IGFBP3 20 & 25.6465 & POL1 20 & 21.7294 & 3.9171 & 0.066196557 & & \\
\hline & \multirow{4}{*}{$\begin{array}{l}\bar{y} \\
\vdots \\
+ \\
\overline{0}\end{array}$} & IGFBP3 21 & 25.9182 & POL1 21 & 22.1445 & 3.7737 & 0.073114431 & \multirow{4}{*}{0.12510767} & \multirow{4}{*}{0.052712988} \\
\hline & & IGFBP3 22 & 23.1279 & POL1 22 & 20.822 & 2.3059 & 0.202234354 & & \\
\hline & & IGFBP3 23 & 24.4609 & POL1 23 & 21.1386 & 3.3223 & 0.099974225 & & \\
\hline & & IGFBP3 24 & 24.9623 & POL1 24 & 22.0556 & 2.9067 & 0.133350949 & & \\
\hline
\end{tabular}

Appendix Table 30: Q-PCR raw $\mathrm{C}_{\mathrm{T}}$ values and calculations for IGFBP-3 mRNA abundance in primary MEC from a Jersey cow cultured for $2 \mathrm{~d}$ and $4 \mathrm{~d}$. 
MEC from Holstein milk (Tables 31-35): raw qPCR values corresponding to results presented in Figure 10.

\begin{tabular}{|c|c|c|c|c|c|c|c|c|c|}
\hline & TX & Sample ID & $\mathbf{C}_{T}$ & HKG ID & $\mathrm{C}_{\mathrm{T}}$ & $\Delta \Delta \mathbf{C}_{\mathrm{T}}$ & $2^{-\Delta \Delta C T}$ & Average & SEM \\
\hline & \multirow{3}{*}{ ڤ్ } & ALAC 1 & 35.4827 & $18 \mathrm{~S} 1$ & 11.4193 & 24.0634 & $5.7042 \mathrm{E}-08$ & \multirow{3}{*}{ 7.28731E-08 } & \multirow{3}{*}{$1.0326 \mathrm{E}-08$} \\
\hline & & ALAC 2 & 35.3123 & $18 \mathrm{~S} 2$ & 11.9428 & 23.3695 & 9.2274E-08 & & \\
\hline & & ALAC 3 & 35.059 & $18 \mathrm{~S} 3$ & 11.2765 & 23.7825 & $6.93033 \mathrm{E}-08$ & & \\
\hline & \multirow{3}{*}{$\hat{\bar{\theta}}$} & ALAC 4 & 34.6648 & $18 \mathrm{~S} 4$ & 11.5985 & 23.0663 & $1.13855 \mathrm{E}-07$ & \multirow{3}{*}{$1.15846 \mathrm{E}-07$} & \multirow{3}{*}{$1.9912 \mathrm{E}-09$} \\
\hline & & ALAC 5 & 34.7661 & $18 \mathrm{~S} 5$ & 11.7494 & 23.0167 & $1.17837 \mathrm{E}-07$ & & \\
\hline 4 & & ALAC 6 & 34.0765 & $18 \mathrm{~S} 6$ & 11.054 & 23.0225 & $1.17365 \mathrm{E}-07$ & & \\
\hline$\vec{\sim}$ & \multirow{3}{*}{ 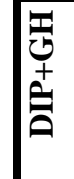 } & ALAC 7 & 34.8795 & $18 \mathrm{~S} 7$ & 12.7561 & 22.1234 & $2.18873 \mathrm{E}-07$ & \multirow{3}{*}{$1.93935 \mathrm{E}-07$} & \multirow{3}{*}{ 2.49383E-08 } \\
\hline & & ALAC 8 & 34.0782 & $18 \mathrm{~S} 8$ & 11.5817 & 22.4965 & $1.68997 \mathrm{E}-07$ & & \\
\hline & & ALAC 9 & 33.3754 & $18 \mathrm{~S} 9$ & 11.1304 & 22.245 & $2.01181 \mathrm{E}-07$ & & \\
\hline \multirow{6}{*}{ 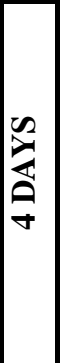 } & \multirow{3}{*}{$\hat{\bar{\theta}}$} & ALAC 10 & 35.7723 & $18 \mathrm{~S} 10$ & 11.9081 & 23.8642 & $6.54877 \mathrm{E}-08$ & \multirow{3}{*}{$1.02858 \mathrm{E}-07$} & \multirow{3}{*}{$4.92585 \mathrm{E}-08$} \\
\hline & & ALAC 11 & 35.7088 & $18 \mathrm{~S} 11$ & 11.2243 & 24.4845 & $4.26021 \mathrm{E}-08$ & & \\
\hline & & ALAC 12 & 34.0201 & $18 \mathrm{~S} 12$ & 11.7701 & 22.25 & $2.00485 \mathrm{E}-07$ & & \\
\hline & \multirow{3}{*}{ 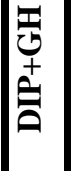 } & ALAC 13 & 34.7988 & $18 \mathrm{~S} 13$ & 11.7107 & 23.0881 & $1.12147 \mathrm{E}-07$ & \multirow{3}{*}{$1.07207 \mathrm{E}-07$} & \multirow{3}{*}{$2.80877 \mathrm{E}-08$} \\
\hline & & ALAC 14 & 35.1879 & $18 \mathrm{~S} 14$ & 11.105 & 24.0829 & $5.62762 \mathrm{E}-08$ & & \\
\hline & & ALAC 15 & 34.6257 & 18S 15 & 11.9876 & 22.6381 & $1.53198 \mathrm{E}-07$ & & \\
\hline
\end{tabular}

Appendix Table 31: Q-PCR raw $\mathrm{C}_{\mathrm{T}}$ values and calculations for $\alpha$-lactalbumin mRNA abundance in MEC from Holstein milk cultured for $2 \mathrm{~d}$ and $4 \mathrm{~d}$. 


\begin{tabular}{|c|c|c|c|c|c|c|c|c|c|}
\hline & TX & Sample ID & $\mathbf{C}_{\mathbf{T}}$ & HKG ID & $\mathbf{C}_{\mathbf{T}}$ & $\Delta \Delta \mathbf{C}_{\mathbf{T}}$ & $2^{-\Delta \Delta C T}$ & Average & SEM \\
\hline & \multirow{3}{*}{ 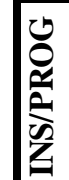 } & CAS 1 & 27.2279 & 18S 1 & 11.4193 & 15.8086 & $1.74236 \mathrm{E}-05$ & \multirow{3}{*}{$1.86508 \mathrm{E}-05$} & \multirow{3}{*}{ 3.68267E-06 } \\
\hline & & CAS 2 & 27.1989 & $18 \mathrm{~S} 2$ & 11.9428 & 15.2561 & $2.55538 \mathrm{E}-05$ & & \\
\hline & & CAS 3 & 27.5104 & $18 \mathrm{~S} 3$ & 11.2765 & 16.2339 & 1.29751E-05 & & \\
\hline \multirow{6}{*}{$\underset{\sim}{\infty}$} & \multirow{3}{*}{$\hat{\bar{\theta}}$} & CAS 4 & 25.5287 & $18 \mathrm{~S} 4$ & 11.5985 & 13.9302 & $6.40607 \mathrm{E}-05$ & \multirow{3}{*}{$3.90745 \mathrm{E}-05$} & \multirow{3}{*}{$1.42258 \mathrm{E}-05$} \\
\hline & & CAS 5 & 27.7938 & $18 \mathrm{~S} 5$ & 11.7494 & 16.0444 & $1.47963 \mathrm{E}-05$ & & \\
\hline & & CAS 6 & 25.7238 & $18 \mathrm{~S} 6$ & 11.054 & 14.6698 & 3.83663E-05 & & \\
\hline & \multirow{3}{*}{$\begin{array}{l}\overline{\mathbf{T}} \\
\mathbf{0} \\
\mathbf{0} \\
\mathbf{0}\end{array}$} & CAS 7 & 26.2087 & $18 \mathrm{~S} 7$ & 12.7561 & 13.4526 & 8.91998E-05 & \multirow{3}{*}{$6.03257 \mathrm{E}-05$} & \multirow{3}{*}{$1.5931 \mathrm{E}-05$} \\
\hline & & CAS 8 & 25.6664 & $18 \mathrm{~S} 8$ & 11.5817 & 14.0847 & 5.7555E-05 & & \\
\hline & & CAS 9 & 25.9651 & $18 \mathrm{~S} 9$ & 11.1304 & 14.8347 & $3.42224 \mathrm{E}-05$ & & \\
\hline \multirow{6}{*}{ 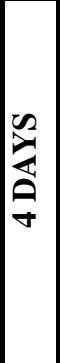 } & \multirow{3}{*}{$\hat{\bar{\alpha}}$} & CAS 10 & 26.1668 & $18 \mathrm{~S} 10$ & 11.9081 & 14.2587 & 5.10157E-05 & \multirow{3}{*}{ 3.7712E-05 } & \multirow{3}{*}{ 9.87572E-06 } \\
\hline & & CAS 11 & 26.9529 & $18 \mathrm{~S} 11$ & 11.2243 & 15.7286 & $1.8417 \mathrm{E}-05$ & & \\
\hline & & CAS 12 & 26.252 & $18 \mathrm{~S} 12$ & 11.7701 & 14.4819 & 4.37032E-05 & & \\
\hline & \multirow{3}{*}{$\begin{array}{l}\frac{\pi}{0} \\
+ \\
\hat{0}\end{array}$} & CAS 13 & 26.8458 & 18S 13 & 11.7107 & 15.1351 & $2.77895 \mathrm{E}-05$ & \multirow{3}{*}{ 3.08542E-05 } & \multirow{3}{*}{ 1.0219E-05 } \\
\hline & & CAS 14 & 27.1406 & $18 \mathrm{~S} 14$ & 11.105 & 16.0356 & 1.48869E-05 & & \\
\hline & & CAS 15 & 26.2786 & 18S 15 & 11.9876 & 14.291 & $4.98862 \mathrm{E}-05$ & & \\
\hline
\end{tabular}

Appendix Table 32: Q-PCR raw $\mathrm{C}_{\mathrm{T}}$ values and calculations for $\alpha_{\mathrm{s} 1}$-casein $\mathrm{mRNA}$ abundance in MEC from Holstein milk cultured for $2 \mathrm{~d}$ and $4 \mathrm{~d}$.

\begin{tabular}{|c|c|c|c|c|c|c|c|c|c|}
\hline & TX & Sample ID & $\mathrm{C}_{\mathrm{T}}$ & HKG ID & $\mathrm{C}_{\mathrm{T}}$ & $\Delta \Delta \mathbf{C}_{\mathbf{T}}$ & $2^{-\Delta \Delta C T}$ & Average & SEM \\
\hline & \multirow{3}{*}{ 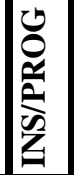 } & GHR 1 & 29.8442 & $18 \mathrm{~S} 1$ & 11.4193 & 18.4249 & 2.84153E-06 & \multirow{3}{*}{ 3.43703E-06 } & \multirow{3}{*}{ 2.97809E-07 } \\
\hline & & GHR 2 & 29.9773 & $18 \mathrm{~S} 2$ & 11.9428 & 18.0345 & $3.72456 \mathrm{E}-06$ & & \\
\hline & & GHR 3 & 29.3031 & $18 \mathrm{~S} 3$ & 11.2765 & 18.0266 & 3.74501E-06 & & \\
\hline \multirow{6}{*}{ 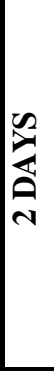 } & \multirow{3}{*}{$\hat{\bar{a}}$} & GHR 4 & 29.6643 & $18 \mathrm{~S} 4$ & 11.5985 & 18.0658 & 3.64462E-06 & \multirow{3}{*}{ 3.16392E-06 } & \multirow{3}{*}{ 3.89627E-07 } \\
\hline & & GHR 5 & 29.8924 & $18 \mathrm{~S} 5$ & 11.7494 & 18.143 & $3.45472 \mathrm{E}-06$ & & \\
\hline & & GHR 6 & 29.7271 & $18 \mathrm{~S} 6$ & 11.054 & 18.6731 & 2.39242E-06 & & \\
\hline & \multirow{3}{*}{ 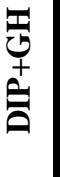 } & GHR 7 & 30.1897 & $18 \mathrm{~S} 7$ & 12.7561 & 17.4336 & 5.64889E-06 & \multirow{3}{*}{$3.67708 \mathrm{E}-06$} & \multirow{3}{*}{$1.06131 \mathrm{E}-06$} \\
\hline & & GHR 8 & 29.7598 & $18 \mathrm{~S} 8$ & 11.5817 & 18.1781 & $3.37168 \mathrm{E}-06$ & & \\
\hline & & GHR 9 & 30.0543 & $18 \mathrm{~S} 9$ & 11.1304 & 18.9239 & $2.01066 \mathrm{E}-06$ & & \\
\hline \multirow{6}{*}{ 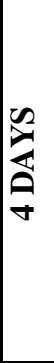 } & \multirow{3}{*}{$\hat{\bar{\alpha}}$} & GHR 10 & 29.1504 & $18 \mathrm{~S} 10$ & 11.9081 & 17.2423 & 6.44986E-06 & \multirow{3}{*}{ 5.3952E-06 } & \multirow{3}{*}{ 9.49014E-07 } \\
\hline & & GHR 11 & 29.348 & $18 \mathrm{~S} 11$ & 11.2243 & 18.1237 & $3.50125 \mathrm{E}-06$ & & \\
\hline & & GHR 12 & 29.0614 & 18S 12 & 11.7701 & 17.2913 & $6.23448 \mathrm{E}-06$ & & \\
\hline & \multirow{3}{*}{ 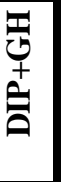 } & GHR 13 & 28.8586 & 18S 13 & 11.7107 & 17.1479 & 6.88601E-06 & \multirow{3}{*}{$5.0225 \mathrm{E}-06$} & \multirow{3}{*}{$1.29484 \mathrm{E}-06$} \\
\hline & & GHR 14 & 29.6955 & $18 \mathrm{~S} 14$ & 11.105 & 18.5905 & $2.53339 \mathrm{E}-06$ & & \\
\hline & & GHR 15 & 29.4214 & 18S 15 & 11.9876 & 17.4338 & $5.64811 \mathrm{E}-06$ & & \\
\hline
\end{tabular}

Appendix Table 33: Q-PCR raw $\mathrm{C}_{\mathrm{T}}$ values and calculations for $\mathrm{GH}$ receptor mRNA abundance in MEC from Holstein milk cultured for $2 \mathrm{~d}$ and $4 \mathrm{~d}$. 


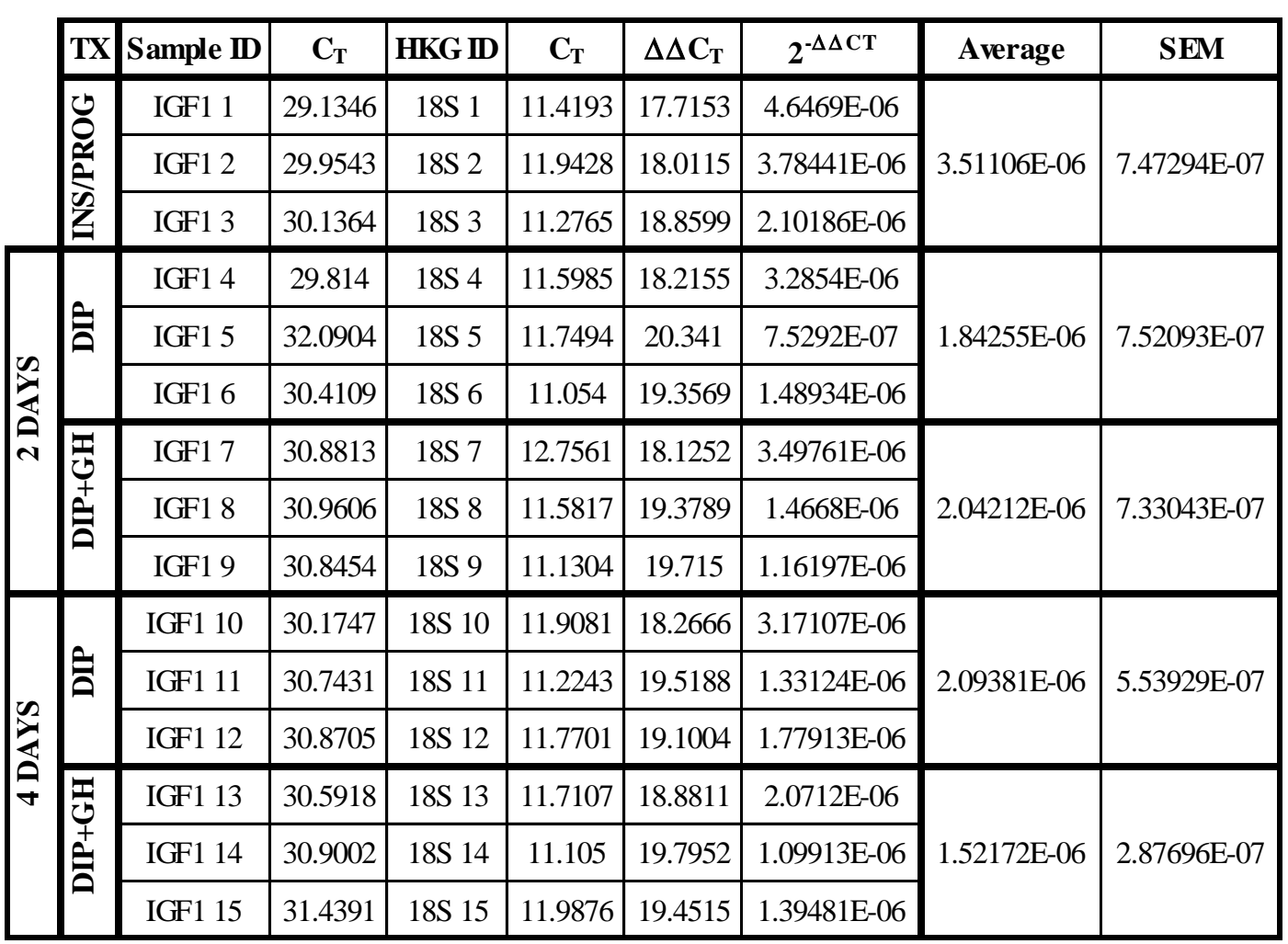

Appendix Table 34: Q-PCR raw $\mathrm{C}_{\mathrm{T}}$ values and calculations for IGF-I mRNA abundance in MEC from Holstein milk cultured for $2 \mathrm{~d}$ and $4 \mathrm{~d}$. 


\begin{tabular}{|c|c|c|c|c|c|c|c|c|c|}
\hline & TX & Sample ID & $\mathrm{C}_{\mathrm{T}}$ & HKG ID & $\mathbf{C}_{\mathrm{T}}$ & $\Delta \Delta \mathbf{C}_{\mathrm{T}}$ & $2^{-\Delta \Delta C T}$ & Average & SEM \\
\hline & \multirow{3}{*}{ ط气 } & IGFBP3 1 & 22.914 & $18 \mathrm{~S} 1$ & 11.4193 & 11.4947 & 0.000346538 & \multirow{3}{*}{0.000497597} & \multirow{3}{*}{0.000130984} \\
\hline & & IGFBP3 2 & 22.3074 & $18 \mathrm{~S} 2$ & 11.9428 & 10.3646 & 0.000758481 & & \\
\hline & & IGFBP3 3 & 22.609 & $18 \mathrm{~S} 3$ & 11.2765 & 11.3325 & 0.000387773 & & \\
\hline & \multirow{3}{*}{$\overline{\bar{\theta}}$} & IGFBP3 4 & 21.2056 & $18 \mathrm{~S} 4$ & 11.5985 & 9.6071 & 0.001282256 & \multirow{3}{*}{0.001118501} & \multirow{3}{*}{0.000115328} \\
\hline & & IGFBP3 5 & 21.4797 & $18 \mathrm{~S} 5$ & 11.7494 & 9.7303 & 0.001177302 & & \\
\hline 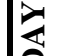 & & IGFBP3 6 & 21.1783 & $18 \mathrm{~S} 6$ & 11.054 & 10.1243 & 0.000895946 & & \\
\hline$\vec{v}$ & \multirow{3}{*}{ 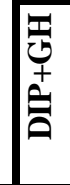 } & IGFBP3 7 & 22.1124 & $18 \mathrm{~S} 7$ & 12.7561 & 9.3563 & 0.001525714 & \multirow{3}{*}{0.000801061} & \multirow{3}{*}{0.000363897} \\
\hline & & IGFBP3 8 & 22.5555 & $18 \mathrm{~S} 8$ & 11.5817 & 10.9738 & 0.00049723 & & \\
\hline & & IGFBP3 9 & 22.4912 & $18 \mathrm{~S} 9$ & 11.1304 & 11.3608 & 0.000380241 & & \\
\hline \multirow{6}{*}{ 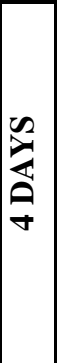 } & \multirow{3}{*}{$\hat{\bar{\theta}}$} & IGFBP3 10 & 20.057 & $18 \mathrm{~S} 10$ & 11.9081 & 8.1489 & 0.003523195 & \multirow{3}{*}{0.00319178} & \multirow{3}{*}{0.000226548} \\
\hline & & IGFBP3 11 & 19.7262 & $18 \mathrm{~S} 11$ & 11.2243 & 8.5019 & 0.002758501 & & \\
\hline & & IGFBP3 12 & 20.0162 & 18S 12 & 11.7701 & 8.2461 & 0.003293643 & & \\
\hline & \multirow{3}{*}{ 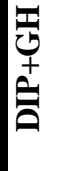 } & IGFBP3 13 & 20.3635 & $18 \mathrm{~S} 13$ & 11.7107 & 8.6528 & 0.002484549 & \multirow{3}{*}{0.001986796} & \multirow{3}{*}{0.000497754} \\
\hline & & IGFBP3 14 & 20.4964 & $18 \mathrm{~S} 14$ & 11.105 & 9.3914 & 0.001489042 & & \\
\hline & & IGFBP3 15 & 20.9867 & 18S 15 & 11.9876 & 8.9991 & 0.001954344 & & \\
\hline
\end{tabular}

Appendix Table 35: Q-PCR raw $\mathrm{C}_{\mathrm{T}}$ values and calculations for IGFBP-3 mRNA abundance in MEC from Holstein milk cultured for $2 \mathrm{~d}$ and $4 \mathrm{~d}$. 
MEC from Jersey milk (Tables 36-40): raw qPCR values corresponding to results presented in Figure 11.

\begin{tabular}{|c|c|c|c|c|c|c|c|c|c|}
\hline & TX & Sample ID & $\mathbf{C}_{\mathbf{T}}$ & HKG ID & $\mathbf{C}_{\mathbf{T}}$ & $\Delta \Delta \mathbf{C}_{\mathrm{T}}$ & $2^{-\Delta \Delta C T}$ & Average & SEM \\
\hline & \multirow{3}{*}{$\begin{array}{l}0 \\
0 \\
\frac{\alpha}{1} \\
\frac{a}{Z}\end{array}$} & ALAC 1 & 36.9548 & АСТВ 1 & 17.3359 & 19.6189 & $1.24200 \mathrm{E}-06$ & \multirow{3}{*}{ 1.64567E-06 } & \multirow{3}{*}{ 5.33074E-07 } \\
\hline & & ALAC 2 & 36.2916 & АСТВ 2 & 17.7941 & 18.4975 & 2.70208E-06 & & \\
\hline & & ALAC 3 & 36.4954 & АСТВ 3 & 16.5536 & 19.9418 & 9.92933E-07 & & \\
\hline \multirow{6}{*}{ 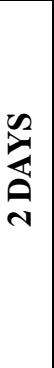 } & \multirow{3}{*}{ 产 } & ALAC 4 & 33.4253 & АСТВ 4 & 17.2348 & 16.1905 & 1.33713E-05 & \multirow{3}{*}{ 7.64075E-06 } & \multirow{3}{*}{ 2.88632E-06 } \\
\hline & & ALAC 5 & 34.2052 & АСТВ 5 & 16.7007 & 17.5045 & $5.37800 \mathrm{E}-06$ & & \\
\hline & & ALAC 6 & 34.2396 & АСТВ 6 & 16.3691 & 17.8705 & 4.17295E-06 & & \\
\hline & \multirow{3}{*}{$\begin{array}{l}\overline{\mathbf{T}} \\
\mathbf{+} \\
\mathbf{1} \\
\hat{0}\end{array}$} & ALAC 7 & 35.6313 & АСТВ 7 & 16.2588 & 19.3725 & $1.47332 \mathrm{E}-06$ & \multirow{3}{*}{ 5.62285E-06 } & \multirow{3}{*}{$2.53920 \mathrm{E}-06$} \\
\hline & & ALAC 8 & 34.4467 & АСТВ 8 & 17.8703 & 16.5764 & $1.02331 \mathrm{E}-05$ & & \\
\hline & & ALAC 9 & 34.1958 & АСТВ 9 & 16.6322 & 17.5636 & 5.16214E-06 & & \\
\hline \multirow{6}{*}{$\underset{2}{\infty}$} & \multirow{3}{*}{$\hat{\overline{0}}$} & ALAC 10 & 35.7032 & АСТВ 10 & 17.827 & 17.8762 & 4.15650E-06 & \multirow{3}{*}{ 5.22433E-06 } & \multirow{3}{*}{ 2.29724E-06 } \\
\hline & & ALAC 11 & 33.7961 & АСТВ 11 & 17.1318 & 16.6643 & 9.62822E-06 & & \\
\hline & & ALAC 12 & 35.3421 & АСТВ 12 & 16.3276 & 19.0145 & 1.88827E-06 & & \\
\hline & \multirow{3}{*}{ 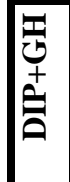 } & ALAC 13 & 34.0834 & АСТВ 13 & 16.5664 & 17.517 & $5.33160 \mathrm{E}-06$ & \multirow{3}{*}{ 5.65707E-06 } & \multirow{3}{*}{ 3.20858E-07 } \\
\hline & & ALAC 14 & 35.4741 & АСТВ 14 & 17.9596 & 17.5145 & 5.34085E-06 & & \\
\hline & & ALAC 15 & 34.5708 & АСТВ 15 & 17.2943 & 17.2765 & $6.29876 \mathrm{E}-06$ & & \\
\hline
\end{tabular}

Appendix Table 36: Q-PCR raw $\mathrm{C}_{\mathrm{T}}$ values and calculations for $\alpha$-lactalbumin mRNA abundance in MEC from Jersey milk cultured for $2 \mathrm{~d}$ and $4 \mathrm{~d}$. 


\begin{tabular}{|c|c|c|c|c|c|c|c|c|c|}
\hline & TX & Sample ID & $\mathbf{C}_{\mathbf{T}}$ & HKG ID & $\mathbf{C}_{\mathbf{T}}$ & $\Delta \Delta \mathbf{C}_{\mathbf{T}}$ & $2^{-\Delta \Delta C T}$ & Average & SEM \\
\hline & \multirow{3}{*}{ 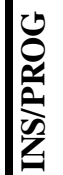 } & CAS 1 & 29.3246 & ACTB 1 & 17.3359 & 11.9887 & 0.0002461 & \multirow{3}{*}{0.0002694} & \multirow{3}{*}{0.0000416} \\
\hline & & CAS 2 & 29.2735 & АСТВ 2 & 17.7941 & 11.4794 & 0.0003502 & & \\
\hline & & CAS 3 & 28.758 & АСТВ 3 & 16.5536 & 12.2044 & 0.0002119 & & \\
\hline \multirow{6}{*}{$\frac{\pi}{2}$} & \multirow{3}{*}{ 会 } & CAS 4 & 27.5161 & ACTB 4 & 17.2348 & 10.2813 & 0.0008036 & \multirow{3}{*}{0.0009078} & \multirow{3}{*}{0.0000617} \\
\hline & & CAS 5 & 26.6418 & ACTB 5 & 16.7007 & 9.9411 & 0.0010173 & & \\
\hline & & CAS 6 & 26.4829 & АСТВ 6 & 16.3691 & 10.1138 & 0.0009025 & & \\
\hline & \multirow{3}{*}{$\begin{array}{l}\mathbf{5} \\
\text { ⿹ } \\
\text { 章 }\end{array}$} & CAS 7 & 27.4095 & АСТВ 7 & 16.2588 & 11.1507 & 0.0004399 & \multirow{3}{*}{0.0012001} & \multirow{3}{*}{0.0003878} \\
\hline & & CAS 8 & 27.0591 & АСТВ 8 & 17.8703 & 9.1888 & 0.0017135 & & \\
\hline & & CAS 9 & 26.0651 & АСТВ 9 & 16.6322 & 9.4329 & 0.0014468 & & \\
\hline \multirow{6}{*}{$\underset{\pi}{\infty}$} & \multirow{3}{*}{$\hat{\bar{\theta}}$} & CAS 10 & 29.2148 & ACTB 10 & 17.827 & 11.3878 & 0.0003732 & \multirow{3}{*}{0.0003319} & \multirow{3}{*}{0.0000482} \\
\hline & & CAS 11 & 28.4687 & АСТВ 11 & 17.1318 & 11.3369 & 0.0003866 & & \\
\hline & & CAS 12 & 28.3777 & ACTB 12 & 16.3276 & 12.0501 & 0.0002358 & & \\
\hline & \multirow{3}{*}{ 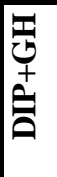 } & CAS 13 & 28.7063 & ACTB 13 & 16.5664 & 12.1399 & 0.0002216 & \multirow{3}{*}{0.0005407} & \multirow{3}{*}{0.0001682} \\
\hline & & CAS 14 & 28.6425 & АСТВ 14 & 17.9596 & 10.6829 & 0.0006083 & & \\
\hline & & CAS 15 & 27.5959 & АСТВ 15 & 17.2943 & 10.3016 & 0.0007923 & & \\
\hline
\end{tabular}

Appendix Table 37: Q-PCR raw $\mathrm{C}_{\mathrm{T}}$ values and calculations for $\alpha_{\mathrm{s} 1}$-casein mRNA abundance in MEC from Jersey milk cultured for $2 \mathrm{~d}$ and $4 \mathrm{~d}$.

\begin{tabular}{|c|c|c|c|c|c|c|c|c|c|}
\hline & TX & Sample ID & $\mathbf{C}_{\mathbf{T}}$ & HKG ID & $\mathbf{C}_{\mathbf{T}}$ & $\Delta \Delta \mathbf{C}_{\mathbf{T}}$ & $2^{-\Delta \Delta C T}$ & Average & SEM \\
\hline \multirow{3}{*}{\multicolumn{2}{|c|}{ 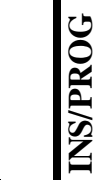 }} & GHR 1 & 28.6422 & АСТВ 1 & 17.3359 & 11.3063 & 0.00039488 & \multirow{3}{*}{0.00041399} & \multirow{3}{*}{0.00015660} \\
\hline & & GHR 2 & 28.2863 & АСТВ 2 & 17.7941 & 10.4922 & 0.00069428 & & \\
\hline & & GHR 3 & 29.2296 & АСТВ 3 & 16.5536 & 12.676 & 0.00015281 & & \\
\hline \multirow{6}{*}{$\frac{\mathscr{n}}{\underset{N}{2}}$} & \multirow{3}{*}{ 寅 } & GHR 4 & 28.8247 & АСТВ 4 & 17.2348 & 11.5899 & 0.00032441 & \multirow{3}{*}{0.00017934} & \multirow{3}{*}{0.00007807} \\
\hline & & GHR 5 & 29.3396 & АСТВ 5 & 16.7007 & 12.6389 & 0.00015679 & & \\
\hline & & GHR 6 & 30.4724 & АСТВ 6 & 16.3691 & 14.1033 & 0.00005682 & & \\
\hline & \multirow{3}{*}{ 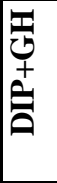 } & GHR 7 & 29.8178 & АСТВ 7 & 16.2588 & 13.559 & 0.00008286 & \multirow{3}{*}{0.00010245} & \multirow{3}{*}{0.00003682} \\
\hline & & GHR 8 & 30.3612 & АСТВ 8 & 17.8703 & 12.4909 & 0.00017373 & & \\
\hline & & GHR 9 & 30.8976 & АСТВ 9 & 16.6322 & 14.2654 & 0.00005078 & & \\
\hline \multirow{6}{*}{$\underset{\nabla}{\mathscr{a}}$} & \multirow{3}{*}{$\hat{\bar{\theta}}$} & GHR 10 & 29.6507 & АСТВ 10 & 17.827 & 11.8237 & 0.00027587 & \multirow{3}{*}{0.00018538} & \multirow{3}{*}{0.00007569} \\
\hline & & GHR 11 & 29.1254 & АСТВ 11 & 17.1318 & 11.9936 & 0.00024523 & & \\
\hline & & GHR 12 & 31.1288 & АСТВ 12 & 16.3276 & 14.8012 & 0.00003503 & & \\
\hline & \multirow{3}{*}{$\begin{array}{l}\frac{\pi}{0} \\
0 \\
0 \\
0\end{array}$} & GHR 13 & 29.2169 & АСТВ 13 & 16.5664 & 12.6505 & 0.00015553 & \multirow{3}{*}{0.00019620} & \multirow{3}{*}{0.00002460} \\
\hline & & GHR 14 & 29.9811 & АСТВ 14 & 17.9596 & 12.0215 & 0.00024053 & & \\
\hline & & GHR 15 & 29.6369 & АСТВ 15 & 17.2943 & 12.3426 & 0.00019253 & & \\
\hline
\end{tabular}

Appendix Table 38: Q-PCR raw $\mathrm{C}_{\mathrm{T}}$ values and calculations for $\mathrm{GH}$ receptor mRNA abundance in MEC from Jersey milk cultured for $2 \mathrm{~d}$ and $4 \mathrm{~d}$. 


\begin{tabular}{|c|c|c|c|c|c|c|c|c|c|}
\hline & TX & Sample ID & $\mathbf{C}_{\mathbf{T}}$ & HKG ID & $\mathbf{C}_{\mathbf{T}}$ & $\Delta \Delta \mathbf{C}_{\mathrm{T}}$ & $2^{-\Delta \Delta C T}$ & Average & SEM \\
\hline & \multirow{3}{*}{ 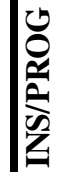 } & IGF1 1 & 30.715 & ACTB 1 & 17.3359 & 13.3791 & 9.3862E-05 & \multirow{3}{*}{ 6.32073E-05 } & \multirow{3}{*}{$1.94066 \mathrm{E}-05$} \\
\hline & & IGF1 2 & 31.6277 & ACTB 2 & 17.7941 & 13.8336 & 6.8497E-05 & & \\
\hline & & IGF1 3 & 31.7163 & АСТВ 3 & 16.5536 & 15.1627 & 2.72629E-05 & & \\
\hline \multirow{6}{*}{$\mid \begin{array}{l}\approx \\
\underset{\sigma}{\sigma} \\
\sim\end{array}$} & \multirow{3}{*}{$\hat{\bar{\theta}}$} & IGF1 4 & 31.5126 & ACTB 4 & 17.2348 & 14.2778 & 5.03447E-05 & \multirow{3}{*}{$3.05633 \mathrm{E}-05$} & \multirow{3}{*}{ 9.92924E-06 } \\
\hline & & IGF1 5 & 32.3723 & ACTB 5 & 16.7007 & 15.6716 & $1.91592 \mathrm{E}-05$ & & \\
\hline & & IGF1 6 & 31.8291 & АСТВ 6 & 16.3691 & 15.46 & 2.21859E-05 & & \\
\hline & \multirow{3}{*}{$\begin{array}{l}\bar{T} \\
0 \\
+ \\
0 \\
0\end{array}$} & IGF1 7 & 32.3105 & ACTB 7 & 16.2588 & 16.0517 & $1.47217 \mathrm{E}-05$ & \multirow{3}{*}{ 2.81245E-05 } & \multirow{3}{*}{$7.90166 \mathrm{E}-06$} \\
\hline & & IGF1 8 & 33.0166 & АСТВ 8 & 17.8703 & 15.1463 & $2.75746 \mathrm{E}-05$ & & \\
\hline & & IGF1 9 & 31.1688 & АСТВ 9 & 16.6322 & 14.5366 & 4.20773E-05 & & \\
\hline \multirow{6}{*}{ 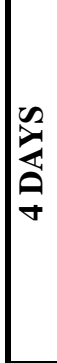 } & \multirow{3}{*}{$\hat{\bar{\theta}}$} & IGF1 10 & 31.871 & АСТВ 10 & 17.827 & 14.044 & 5.92018E-05 & \multirow{3}{*}{ 3.92231E-05 } & \multirow{3}{*}{$1.43526 \mathrm{E}-05$} \\
\hline & & IGF1 11 & 31.5062 & АСТВ 11 & 17.1318 & 14.3744 & 4.70841E-05 & & \\
\hline & & IGF1 12 & 32.7503 & АСТВ 12 & 16.3276 & 16.4227 & $1.13835 \mathrm{E}-05$ & & \\
\hline & \multirow{3}{*}{$\begin{array}{l}\bar{T} \\
0 \\
+ \\
0 \\
0 \\
0\end{array}$} & IGF1 13 & 31.981 & ACTB 13 & 16.5664 & 15.4146 & $2.28951 \mathrm{E}-05$ & \multirow{3}{*}{ 2.42725E-05 } & \multirow{3}{*}{$1.42617 \mathrm{E}-05$} \\
\hline & & IGF1 14 & 32.2579 & АСТВ 14 & 17.9596 & 14.2983 & 4.96344E-05 & & \\
\hline & & IGF1 15 & 39.0223 & АСТВ 15 & 17.2943 & 21.728 & $2.87886 \mathrm{E}-07$ & & \\
\hline
\end{tabular}

Appendix Table 39: Q-PCR raw $\mathrm{C}_{\mathrm{T}}$ values and calculations for IGF-I mRNA abundance in MEC from Jersey milk cultured for $2 \mathrm{~d}$ and $4 \mathrm{~d}$.

\begin{tabular}{|c|c|c|c|c|c|c|c|c|c|}
\hline & $\mathbf{T X}$ & Sample ID & $\mathbf{C}_{\mathbf{T}}$ & HKG ID & $\mathbf{C}_{\mathbf{T}}$ & $\Delta \Delta \mathbf{C}_{\mathbf{T}}$ & $2^{-\Delta \Delta C T}$ & Average & SEM \\
\hline & \multirow{3}{*}{ 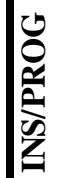 } & IGFBP3 1 & 20.4037 & АСТВ 1 & 17.3359 & 3.0678 & 0.119261 & \multirow{3}{*}{0.117997} & \multirow{3}{*}{0.025489} \\
\hline & & IGFBP3 2 & 20.4245 & АСТВ 2 & 17.7941 & 2.6304 & 0.161499 & & \\
\hline & & IGFBP3 3 & 20.325 & АСТВ 3 & 16.5536 & 3.7714 & 0.073231 & & \\
\hline \multirow{6}{*}{$\begin{array}{l}\underset{2}{2} \\
\underset{a}{N}\end{array}$} & \multirow{3}{*}{$\hat{\bar{\theta}}$} & IGFBP3 4 & 19.7434 & АСТВ 4 & 17.2348 & 2.5086 & 0.175726 & \multirow{3}{*}{0.078838} & \multirow{3}{*}{0.048567} \\
\hline & & IGFBP3 5 & 22.0573 & АСТВ 5 & 16.7007 & 5.3566 & 0.024406 & & \\
\hline & & IGFBP3 6 & 21.1498 & АСТВ 6 & 16.3691 & 4.7807 & 0.036380 & & \\
\hline & \multirow{3}{*}{$\begin{array}{l}\bar{T} \\
0 \\
+ \\
\overline{0} \\
\overline{0}\end{array}$} & IGFBP3 7 & 20.0309 & АСТВ 7 & 16.2588 & 3.7721 & 0.073196 & \multirow{3}{*}{0.179820} & \multirow{3}{*}{0.101473} \\
\hline & & IGFBP3 8 & 19.2561 & АСТВ 8 & 17.8703 & 1.3858 & 0.382677 & & \\
\hline & & IGFBP3 9 & 20.2128 & АСТВ 9 & 16.6322 & 3.5806 & 0.083586 & & \\
\hline \multirow{6}{*}{$\underset{⿱}{\sigma}$} & \multirow{3}{*}{$\hat{\bar{\theta}}$} & IGFBP3 10 & 18.7936 & АСТВ 10 & 17.827 & 0.9666 & 0.511711 & \multirow{3}{*}{0.559820} & \multirow{3}{*}{0.193940} \\
\hline & & IGFBP3 11 & 17.2565 & АСТВ 11 & 17.1318 & 0.1247 & 0.917195 & & \\
\hline & & IGFBP3 12 & 18.3244 & АСТВ 12 & 16.3276 & 1.9968 & 0.250555 & & \\
\hline & \multirow{3}{*}{ 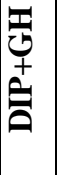 } & IGFBP3 13 & 18.1136 & АСТВ 13 & 16.5664 & 1.5472 & 0.342174 & \multirow{3}{*}{0.535663} & \multirow{3}{*}{0.200015} \\
\hline & & IGFBP3 14 & 18.0556 & АСТВ 14 & 17.9596 & 0.096 & 0.935623 & & \\
\hline & & IGFBP3 15 & 18.8973 & АСТВ 15 & 17.2943 & 1.603 & 0.329192 & & \\
\hline
\end{tabular}

Appendix Table 40: Q-PCR raw $\mathrm{C}_{\mathrm{T}}$ values and calculations for IGFBP-3 mRNA abundance in MEC from Jersey milk cultured for $2 \mathrm{~d}$ and $4 \mathrm{~d}$. 